\title{
Helicobacter pylori Related Diseases and Osteoporotic Fractures (Narrative Review)
}

\author{
Leon Fisher 1,*(D), Alexander Fisher ${ }^{2,3,4}$ and Paul N Smith ${ }^{3,4}$ \\ 1 Department of Gastroenterology, Frankston Hospital, Peninsula Health, Melbourne 3199, Australia \\ 2 Department of Geriatric Medicine, The Canberra Hospital, ACT Health, Canberra 2605, Australia; \\ Alex.Fisher@act.gov.au \\ 3 Department of Orthopedic Surgery, The Canberra Hospital, ACT Health, Canberra 2605, Australia; \\ paul.smith@act.gov.au \\ 4 Australian National University Medical School, Canberra 2605, Australia \\ * Correspondence: leonfisher@optusnet.com.au
}

Received: 21 August 2020; Accepted: 7 October 2020; Published: 12 October 2020

\begin{abstract}
Osteoporosis (OP) and osteoporotic fractures (OFs) are common multifactorial and heterogenic disorders of increasing incidence. Helicobacter pylori (H.p.) colonizes the stomach approximately in half of the world's population, causes gastroduodenal diseases and is prevalent in numerous extra-digestive diseases known to be associated with OP/OF. The studies regarding relationship between H.p. infection (HPI) and OP/OFs are inconsistent. The current review summarizes the relevant literature on the potential role of HPI in OP, falls and OFs and highlights the reasons for controversies in the publications. In the first section, after a brief overview of HPI biological features, we analyze the studies evaluating the association of HPI and bone status. The second part includes data on the prevalence of OP/OFs in HPI-induced gastroduodenal diseases (peptic ulcer, chronic/atrophic gastritis and cancer) and the effects of acid-suppressive drugs. In the next section, we discuss the possible contribution of HPI-associated extra-digestive diseases and medications to $\mathrm{OP} / \mathrm{OF}$, focusing on conditions affecting both bone homeostasis and predisposing to falls. In the last section, we describe clinical implications of accumulated data on HPI as a co-factor of OP/OF and present a feasible five-step algorithm for OP/OF risk assessment and management in regard to HPI, emphasizing the importance of an integrative (but differentiated) holistic approach. Increased awareness about the consequences of HPI linked to OP/OF can aid early detection and management. Further research on the HPI-OP/OF relationship is needed to close current knowledge gaps and improve clinical management of both OP/OF and HPI-related disorders.
\end{abstract}

Keywords: Helicobacter pylori infection; osteoporosis; fractures; falls; medications; management

\section{Introduction}

Both Helicobacter pylori (H.p.) infection (HPI) and osteoporotic fractures (OFs) constitute major challenges for public health systems globally due to huge clinical and economic burdens. Accumulating evidence suggests that in health and disease stomach and gut directly and indirectly via multiple neurohormonal pathways regulate the musculoskeletal and other systems by controlling appetite, food intake, absorption of nutrients and energy balance [1-7]. These physiological relationships (including the gut/stomach-bone axis) may be affected by HPI. HPI is associated with numerous diseases in and outside the stomach, many of which have the potential to influence bone and muscle status, predispose to falls and, consequently, contribute to OFs. As H.p. colonizes the human stomach in over $50 \%$ of the world's population [8-11] and HPI frequently coexists with OP/OF, deeper understanding the relationships among HPI-related diseases, the skeleton and falls becomes highly important; it may 
help to improve the preventive and therapeutic strategies for OFs. However, only a small number of studies have examined the association between HPI and bone status and the results have been controversial [12-14]. Although conventional wisdom suggests that in clinical practice the two main components of OFs-OP and falls-need to be integrated and viewed under complementary angles, the possible contribution of HPI-associated diseases to falls has not been addressed in the literature systematically.

Each year thousands of papers are published on HPI, OP and OFs. In this narrative review based mainly on the literature from the last decade, we present basic information on HPI, summarize the key findings and existing evidence in the literature for and against the impact of HPI-induced and -associated diseases on skeleton, falls and OFs, highlight the possible causes for controversies, discuss the practical implications of the accumulating knowledge and introduce a practical algorithm for management OP/OF incorporating the new data on the potential role of HPI.

\section{Brief Overview of Helicobacter pylori Infection}

H.p. is a spiral-shaped, flagellated, microaerophilic, Gram-negative bacterium, which coevolved with humans $>50,000$ years [9,15]. The bacterium, discovered in 1982 by Warren and Marshall [16,17], colonizes the stomach in approximately 4.4 billion individuals $[10,18]$ and is currently recognized as the most important microbiological agent in human upper gastrointestinal tract disorders. The prevalence of HPI (about $30 \%$ in developed countries and up to $80 \%$ in developing countries) varies by age (higher in the elderly, especially among institutionalized people); socioeconomic, urbanization and sanitation conditions; lifestyle and diet factors; and geographical regions (Central/South America, Asia, Eastern and Southern Europe have 50-80\% higher prevalence than the rest of the world) [19]. In the past decades, the HPI rates declined in developed countries but remained high in rest of the world.

The long co-existence of H.p. with humans resulted in high level of genetic diversity and extensive polymorphism (especially among strains from different ethnic and geographic origins [20]), multiple strategies and complex mechanisms of colonization and persistence, ability to maintain a mild inflammation of the gastric epithelium and escape from and/or attenuate host immune system response (Figure 1).

Although the gastric mucosa is well protected against infection, H.p., compared to most bacteria and viruses, is well adapted to survive in acidic conditions of the human stomach. It produces urease, an enzyme which hydrolyses urea causing the $\mathrm{pH}$ rise (essential for stomach colonization), and gamma-glutamyl transpeptidase, an enzyme which supports its growth and survival in the gastric mucosa. Acute HPI affects also the parietal cell proton pump mechanism, increases production of cytokines and activates neural pathways that stimulate somatostatin and inhibit both histamine production and acid secretion [21-24]. Furthermore, H.p. alters the mucus barrier by modulating the expression of stomach mucins [25]. These mechanisms counteract the acidic environment of the stomach (first defense line) and play a key role in H.p. survival and colonization. Urease, in addition to its role in acid neutralization, contributes to H.p. pathogenicity by production ammonia (disrupts cell junctions and damages epithelium) and reactive oxygen species (ROS), activating lipoxygenase, inducing angiogenesis, hypoxia-induced factor and apoptosis [26-30]. The helical shape and flagella, two factors responsible for bacterial mobility, also contribute to colonization and persistence of the infection (allow H.p. to escape low gastric $\mathrm{pH}$ by moving to the "protective" mucus layer before colonizing the gastric epithelium).

H.p. strains (the microbe encompasses approximately 1600 genes) have different genes encoding virulence factors (encoded proteins) which are secreted, membrane-associated or translocated into cytosol of the host cells via the IV type secretion system, where they can affect the host cell functions. The most studied virulence factors implicated in the pathogenicity of H.p. are produced by strains containing the following genes $[29,31]$ : cytotoxin-associated gene A (cagA), vacuolating cytotoxin gene (vacA), duodenal ulcer (DU) promoting gene (dupA), induced by contact with epithelium gene (iceA), blood group antigen-binding adhesin (babA), sialic acid binding adhesin (sabA), outer inflammatory 
protein A (oipA), adherence-associated lipoprotein A and B (alpA/B), H.p. outer membrane protein $\mathrm{Q}$ (hopQ), gamma-glutamyl transpeptidase (GGT) and high-temperature requiring protein (HtrA). The regulation and function of the proteins encoded by these genes are complex processes. Gastric acidity is detected by the H.p. and serves as a trigger to increase production of pathogenic factors needed to subvert host defense [32]. H.p. strains carrying virulence factors are considered more pathogenic compare to the strains lacking these factors.

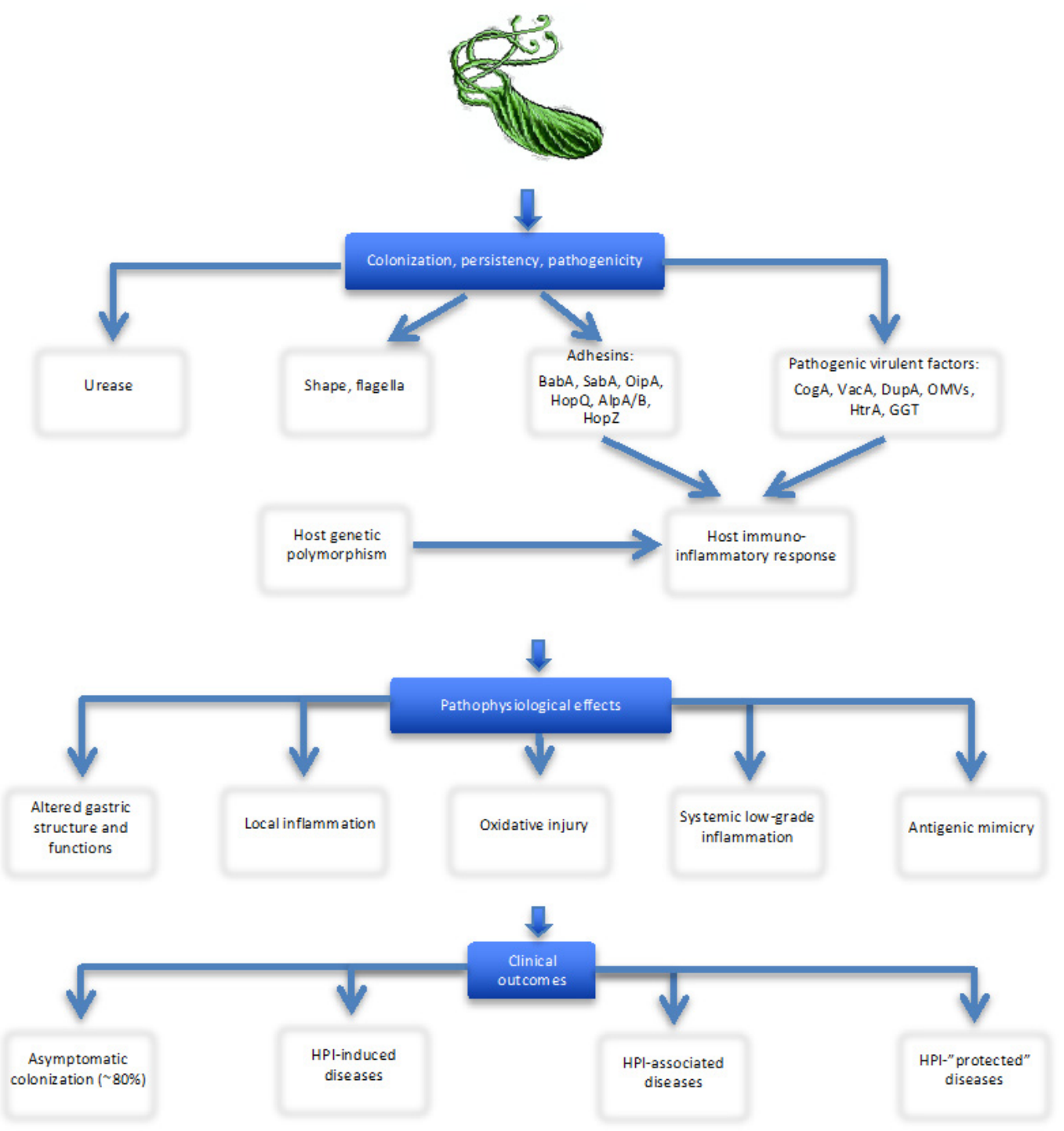

Figure 1. Overview of Helicobacter pylori (H.p.) characteristics contributing to gastric colonization, persistence, pathogenicity and clinical outcomes. Abbreviations: AlpA/B, adherence-associated lipoprotein A and B; BabA, blood group antigen-binding adhesin; CagA, cytotoxin associated antigen A; DupA, duodenal ulcer (DU) promoting antigen; GGT, gamma-glutamyl transpeptidase; HopQ, HopZ, H. pylori outer membrane proteins; HtrA, high-temperature requiring protein; OipA, outer inflammatory protein; OMVs, outer membrane vesicles; SabA, sialic acid-binding adhesin; VacA, vacuolating cytotoxin. Notes: The outcome of H.p. is multifactorial and depends on interaction between multiple heterogenic bacterial virulence factors, host genetics, lifestyle and environmental influences. H.p. utilizes a variety of mechanisms which allow: (1) escaping high acid environment (urease, bacterial shape and flagella); (2) attaching to the gastric epithelial layer (adhesin proteins); (3) exerting epithelial cell pathogenicity and (4) affecting the host innate and adaptive immune responses. The expression of virulence factors and host's immunologic responses (dependent of genetic predisposition/resistance, 
e.g., proinflammatory cytokine gene polymorphisms) are critical to host colonization, infection persistence and pathogenesis of local (gastroduodenal) and systemic (extra-digestive) diseases. The cascade of pathophysiologic events in the stomach includes acid neutralization, mucus layer destruction, immune cell activation (lymphocytes, macrophages, dendritic cells, natural killer and mast cells), upregulation of pro-inflammatory (IL-1 $\beta$, IL-6, IL-8, IL-17,TNF- $\alpha$, IFN- $\gamma$ and CRP) and anti-inflammatory (IL-4 and IL-10) cytokines (immune-inflammatory axes) and increased production of reactive oxygen species (oxidative stress) causing cell damage, alterations of gastric structure and functions (including changes in gastric acid and pepsin secretion, hormone production) as well as numerous effects on the gut (motility and microbiota) and extra-digestive organs; these may result in gastroduodenal erosion, peptic ulcer, carcinogenesis or lymphoma formation, as well as contribute to development and progression of numerous chronic diseases outside the stomach (CVDs, neurodegenerative, hematologic, metabolic, CKDs, CLDs, etc.); however, the role of HPI is not necessarily detrimental, it may even be "protective" (asthma in children; allergy; IBD, especially Crohn's disease; and autoimmune disorders). Infection with virulent strains (in particular, cagA+ and vacA+) is associated with higher inflammatory response, oxidative injury and elevated risk of gastroduodenal and most extra-digestive diseases.

H.p. induces activation of most components of innate (epithelial, neutrophil, macrophage and dendritic cells) and adaptive immunity (B and T cells) [30,33-35]. H.p., especially with specific virulent strains, in addition to a local reaction results in systemic low-grade inflammation [36-38]. Exosomes (extracellular phospholipid vesicles formed by exocytosis) containing CagA and other virulence factors, can be distributed by the circulation and might be involved in the development of extragastric disorders [39-42]. Furthermore, molecular cross-mimicry between H.p. components and gastric $\mathrm{H} / \mathrm{K}$-ATPase, platelet surface, endothelial, fibroblast and smooth muscle cells as well as atherosclerotic plaque antigens may trigger immune and inflammatory responses and tissue destruction [11,42-44]. Noticeable, H.p. has the ability to induce and modulate host's immuno-inflammatory responses and to protect itself by blunting host's ability to eliminate the bacteria: the long-standing inflammatory environment is harmful to the host but tolerant for the microbe (favors persistence).

With regard to OP, CagA is the only H.p. virulence factor evaluated so far. CagA is a $125-140 \mathrm{kDa}$ protein encoded in the complex of the cytotoxin associated gene pathogenicity island (cag PAI) and delivered into gastric epithelial cells via bacterial type IV secretion system [45-47]. The C-terminal region of CagA contains multiple Glu-Pro-Ile-Tyr-Ala (EPIYA) motifs. Various combinations of four different EPIYA segments (A-D) create structural polymorphism that enables classification of individual CagA into subtypes; the two major subtypes are the Western and the East Asian (Japan, China and Korea). Almost all CagA carry EPIYA-A and -B; EPIYA-C is prevalent in Western countries (ABC-type CagA), while EPIYA-D -is prevalent in East Asian countries (ABD-type CagA). CagA possesses also a 16-amino-acid sequence termed CagA multimerization (CM) sequence, two CM in the Western CagA type and one CM in the East Asian type [48-50]. CagA interacts with 25 host cell receptors in the gastric epithelium demonstrating the highest quantity of all known virulence-associated effector proteins in the microbial world [51]. CagA-positivity has been shown to be associated with increased production of proinflammatory (IL-1 $\beta$, IL-6, IL-8, IL-17, TNF- $\alpha$, IFN- $\gamma$ and CRP) and anti-inflammatory (IL-4 and IL-10) cytokines, suppressed phagocytosis, induced tolerogenic dendritic cells and blocked T cell responses [52-54]. H.p. strains that express CagA often also express other virulence factors (e.g., VacA, BabA, etc.); such strains tend to influence more host immune responses. In Western countries only $30-40 \%$ of strains have cagA, whereas in East Asian countries up to $100 \%$ of strains carry cagA [55-62]. The serological immune response to H.p. cagA+ strains in various geographic regions of the world ranges from 32\% to 80\% [63-65], with the lowest prevalence in Europe and highest in Asian countries.

CagA plays a critical role in the development of peptic ulcer disease (PUD), chronic gastritis, gastric cancer and mucosa-associated lymphoid tissue (MALT) B-cell lymphoma [41,65-67], as well as many extra-gastroduodenal diseases [68]. In Western countries, subjects infected with cagA-positive (cagA+) strains compared to those infected with cagA-negative (cagA-) strains of H.p. are at a 1.7-2.8-times 
higher risks of both PUD or gastric cancer $[57,67,69]$, whereas, in the East Asian population, in which most H.p. strains carry cagA gene, these risks are 2.8-4.6-times higher [67]. The interactions between various bacterial virulence factors and their contribution to the immune and clinical phenotype of HPI outcome are complex; for instance, vacA polymorphism was found as one of the most important factors associated with anti-CagA-IgG seropositivity [65].

H.p. is acquired during childhood (within the first 5-10 years of life) via oral-oral and fecal-oral routes or contaminated water and unless eradicated by treatment persists for life. The specific virulence factors (abovementioned proteins encoded by the H.p. genes) are associated with microorganism's survival/adaptation, anatomical distribution and pathogenicity (including effects on host immune and inflammatory responses). The variety of HPI clinical manifestations (development of different HPI-related diseases or asymptomatic survival) is also significantly influenced by the host genetic polymorphisms including cytokine gene polymorphisms [33,70-72]. As in the majority of subjects the immune system is unable to eradicate the HPI, acute gastritis is followed by chronic gastritis (histologic gastritis is present in all individuals with HPI) in one of three forms: (1) corpus/fundus-predominant; (2) antral-predominant; and (3) diffuse. The topographic distribution of chronic HPI-induced gastritis is at least partly host specific [8].

Although most (70-80\%) infected individuals are asymptomatic, HPI is etiologically associated with acute gastric inflammation, chronic non-atrophic and atrophic gastritis, PUD (approximately in 10\%), gastric adenocarcinoma (in 1-3\%) and MALToma (in <0.1\%) [73-77]. Moreover, HPI in addition to diverse gastroduodenal pathologies has been reported to be associated with multiple extra-digestive disorders, including cardiovascular, neurological, hematological, endocrine and other diseases known to be linked to OP/OF. However, some diseases (allergic, autoimmune and metabolic) are observed more frequently in subjects free of H.p. $[9,75,78,79]$ suggesting that HPI may have a potentially "protective" effect.

In chronic HPI, the physiologically tightly regulated gastric acid, pepsin and hormonal (peptides and amines) secretion status is determined by the predominantly affected anatomic site. HPI-induced predominantly antral gastritis decreases the D-cell numbers and production of the inhibitory peptide somatostatin by these cells, increases production of gastrin (by antral G-cells), acid (by parietal cells), and pepsin (by chief cells), predisposing to duodenal ulcer disease. Corpus/fundus infection is associated with loss of parietal, chief and endocrine type cells, various degrees of atrophic gastritis and intestinal metaplasia resulting in reduced acid and pepsin secretion, lower levels of ghrelin (a pleiotropic hormone synthesized and secreted mainly by fundic P/D1 cells in humans and by gastric $\mathrm{X} / \mathrm{A}$-like endocrine cells in rodents) and histamine production (by the enterochromaffin-like cells, ECL) and elevated gastrin and gastric leptin secretion; these predispose to gastric ulceration and/or gastric cancer but protect against duodenal ulceration and, probably, against acid-induced gastroesophageal reflux disease (GERD) [58,80-84]. The changes in gastric structure and function are caused by products of H.p. itself and/or upregulated expression of proinflammatory cytokines released in response to HPI, especially with more virulent strains (e.g., cagA+, VacA, etc.).

Of note, H.p. has been detected in numerous sites throughout the body, beyond the stomach, including the oral and nasal cavities, gall bladder, large intestine, liver, coronary arteries, trabeculum, iris and skin $[85,86]$; emerging data indicate that the oral cavity can act as an extragastric reservoir of HPI [87-89], although some researchers oppose this conclusion [90,91].

In sum, the outcome of HPI is determined by the interactions of: (1) HPI virulence factors; (2) hosts' age, gender and immune-inflammatory response (dependent on both host's genetic susceptibility/resistance and H.p. characteristics); and (3) environmental and lifestyle factors (diet, cigarette smoking, alcohol consumption, sanitation and air pollution) $[8,9,60,67,92-94]$. Although colonization with H.p. is not a disease in itself, the condition significantly increases the risk of developing various clinical disorders-gastroduodenal and extra-digestive. This short overview provides background information on the complexity of factors involved in the pathogenesis of HPI-related diseases: genetic and geographic heterogeneity of the bacterium, the diversity of molecular 
mechanisms responsible for its persistence and effects in the human stomach, differences in host's susceptibility and role of socioeconomic, sociodemographic, environmental, cultural and lifestyle factors (Figure 1). Understandable, these aspects as main determinants of HPI clinical outcomes should be taken into account when the relationship between H.p. (potentially commensal/symbiotic bacteria) and any clinical disorder is studied. Precise knowledge of HPI virulent factors, host susceptibility and environmental conditions are essential to understand and explain the variety of HPI clinical effects, including the potential HPI-OP/OF link.

\section{HPI and Bone Status}

Data on the relationship between HPI and OP are limited and controversial. Most studies were retrospective, single-center, cross-sectional, non-randomized (Table 1). Two recent meta-analyses came to opposite conclusions [12,14]. The first analysis [12], which included five studies involving 1321 participants (1068 women), found no significant association between HPI and OP (pooled OR $1.49,95 \%$ CI $0.88-2.55, p=0.14$ ). In the second report [14], based on 21 observational studies with 9655 participants, HPI was significantly associated with OP (OR 1.39, 95\% CI 1.13-1.71, $p<0.001$ ). The results of these two meta-analyses should be interpreted cautiously in light of heterogeneity (stated by the authors of both reports) and obvious limitations: no information on H.p. virulence factors, host's inflammatory/immunological responses and environmental factors, often small sample sizes, as well as lack of data on main risk factors for OP and no adjustment for such potential confounders as site, type and severity of gastric pathology; comorbidities; race/ethnicity; and pharmacotherapy used.

We identified 20 original studies (duplicated publications excluded) on the topic; these included in total 38,558 subjects (38,497 adults and 61 adolescents). Six studies included only women, mainly postmenopausal; in one report, the gender of the participants was not mentioned [95], in the rest of the studies there were 5801 males and 5522 females (M:F ratio 1:1.05). Of the 20 studies, 19 had a cross-sectional design, one analyzed a prospective cohort [96]. Nine studies were performed in Western countries (Italy, Turkey, Brazil (two reports from each) and Iran (three reports)) and eleven studies in Eastern countries/regions (Japan (five reports), Taiwan (four), South Korea (one) and China (one)).

A positive relationship between HPI and osteoporotic characteristics was demonstrated in nine studies, mainly from Eastern countries/regions (Japan (three reports), Taiwan (three reports) and Korea (one report)), and in two studies from Italy. In contrast, among the 11 studies which did not find such association, seven were from Western countries (Turkey, Brazil (two reports from each) and Iran (three reports)) and four from Eastern countries/regions (Japan (two reports), Taiwan (one) and China (one)). In other words, an association between HPI and bone mineral density (BMD) status has been observed in seven of eleven studies undertaken in Eastern countries and only in two of nine studies from Western countries. In one study, HPI was associated with BMD only at the lumbar spine but not at the femoral neck [97] indicating that the trabecular bone may be more affected than the cortical bone. The influence of HPI on bone health (and other organs) is not dependent only on the presence of the infection itself but is closely related to microbe's virulence factors. Therefore, association with geography is to be expected, as Asian populations almost invariably have cagA+ H.p. strains.

Among the HPI virulent factors only the cagA genotype was evaluated in two Italian studies $[98,99]$. In the first of these studies ( $n=240$ men), 51 of $80(63.7 \%)$ patients with OP and 107 of $160(66.8 \%)$ non-OP controls were seropositive for HPI, but individuals infected by a cagA+ strain compared to a cagA- demonstrated significantly increased bone resorption (as defined by higher amounts of urinary cross-laps), reduced estrogen levels but similar BMD [98]. The second study ( $n=1118$, including 935 women and 183 men) presented the following additional data supporting the notion that cagA + H.p. should be considered as a risk factor for OP and fractures in both genders: (1) a significant negative association between anti-CagA antibody titer and BMD; (2) a higher prevalence of cagA+ H.p. in osteoporotic $(30 \%)$ and osteopenic $(26 \%)$ patients compared to subjects with normal BMD $(21 \%)$, although the overall HPI prevalence in the three groups did not differ significantly $(41.5 \%, 46.2 \%$ and $43.9 \%$, respectively); (3) only $30 \%$ of females and $14 \%$ of males with anti-CagA antibody titer 
above the median level had a normal BMD; and (4) hip and symptomatic vertebral fractures occurred in $4 \%$ of cagA+, in $2 \%$ of cagA- patients and in $0.8 \%$ of uninfected subjects $(p<0.05$ for cagA+ vs. uninfected individuals) [99].

Other researchers, unfortunately, did not differentiate patients by H.p. virulence strains. However, findings in seven of eleven studies from Eastern countries indicate that prevalence of OP is approximately two-fold higher among individuals with HPI; in multivariate logistic regression analyses (after adjusting for age, gender, body mass index (BMI) and use of proton pump inhibitors (PPIs)), odds ratios (ORs) for OP ranged between 1.62 and 5.33 (Table 1). In this regard, it is interesting to compare geographic differences in cagA+ prevalence and variations in fracture epidemiology. In the last two decades, hip fracture rates are declining in Northern Europe, North America and Oceania [100] and increasing in Asian countries (Japan, Korea, Singapore and Lebanon) [101], where HPI prevalence is higher and most H.p. strains are cagA+; the rates of vertebral fractures in Asia are also among the highest in the world [102]. It was projected that in Southeast Asian countries in 2050 compared to 2018 hip fracture rates may increase 2.8-5.6-fold $[103,104]$. The differences in H.p. virulence, host and environmental factors in West and East may, at least partially, explain the role of cagA+ H.p. in OP/OF.

The relationships between HPI and bone turnover markers were addressed in three studies $[96,98,105]$. In adolescents, HPI was not accompanied by significant changes in serum levels of bone formation markers ( $\mathrm{N}$-terminal cross-links of human procollagen type I (P1NP), N-mid-osteocalcin $(\mathrm{OC})$ and bone-specific alkaline phosphatase (bALP)), bone resorption marker ( $\beta$-collagen I carboxy terminal telopeptide $(\beta-C T X))$, calcium and phosphate, as well as in circulating estradiol, intact parathyroid hormone (PTH) and ferritin levels, but a tendency to increased bone resorption (as reflected by higher $\beta$-CTX levels, $p=0.063$ ) was observed [105]. In this study, the decreased vitamin B12 level was the only parameter differentiating the groups with and without HPI. Consistent with these findings are results from a prospective cohort study on postmenopausal women [96]: 5.8 years of follow-up revealed no significant differences between the H.p. seropositive and seronegative subjects in BMD and age-adjusted bone turnover markers (osteoprotegerin (OPG), receptor activator of nuclear factor kappa B ligand (RANKL), the RANKL/OPG ratio, OC and cross-laps); the differences between groups in BMD and serum OPG levels observed on univariate analysis were lost after adjusting for age. In logistic regression analyses, both H.p. and Chlamydia pneumoniae seropositivities did not predict incident lumbar spine or femoral neck OP [96].

The influence of HPI eradication therapy on BMD has been reported in two studies. The Japanese study $(n=255)$ found that H.p. seropositivity was an independent and significant risk factor for OP (OR 3.00, 95\% CI 1.31-6.88, $p=0.009$ ), whereas the success of H.p. eradication was not related to OP; use of PPIs was associated with a tendency $(p=0.073)$ towards OP [106]. Data from a large Taiwan's National Health Insurance Research Database (5447 patients with PUD treated for HPI) demonstrated that early microbe eradication (within one year of being diagnosed) reduced the effect of infection on development of OP when the follow-up period was above 5 years [95].

The complexity of HPI-host interaction may contribute to the discrepancies observed in the reported studies. The many contradictory results could be due to abovementioned variations in multiple factors influencing the HPI outcome including the microbe's specific virulence constituents (e.g., cagA and vacA); host's demographic, genetic and clinical parameters; and environmental characteristics; these factors in fact were not considered in most of the studies. Obviously, the analysis of HPI-OP/OF association needs to be more complex. 
Table 1. Data on relationship between H. pylori infection (HPI) and bone status/osteoporosis.

\begin{tabular}{|c|c|c|c|c|c|c|c|c|}
\hline $\begin{array}{l}\text { First Author, Year, } \\
\text { Reference No, } \\
\text { Country/Region }\end{array}$ & $\begin{array}{l}\text { Population, } \\
\text { Gender } \\
\text { (F/M) }\end{array}$ & $\begin{array}{l}\text { Mean Age, } \\
\text { Years }\end{array}$ & $\begin{array}{l}\text { HPI Detection } \\
\text { Method }\end{array}$ & $\begin{array}{l}\text { HPI Strain } \\
\text { Identification }\end{array}$ & $\begin{array}{c}\text { Bone Status } \\
\text { Assessment Methods, } \\
\text { Skeletal Location }\end{array}$ & $\underset{(\%)}{\mathrm{HPI}+\underset{\mathrm{ond}}{\mathrm{O}} \mathrm{OP}, n}$ & $\begin{array}{l}\text { HPI+ and Non } \\
\text {-OP/Controls }\end{array}$ & $\begin{array}{l}\text { Association } \\
\text { (Yes/No) }\end{array}$ \\
\hline Figura N, 2005 [98], Italy & $240, \mathrm{M}$ & $65(55-82)$ & Serum antibody & CagA & $\begin{array}{c}\text { DEXA, LS, FN; } \\
\text { Urinary cross-laps, } \\
\text { serum bALP, PTH, Ca, } \\
\mathrm{PO}_{4}, 25(\mathrm{OH}) \mathrm{D}\end{array}$ & $\begin{array}{c}\text { 51/80 }(63.7 \%) \\
\text { CagA+: } 30 \\
(58.8 \%)\end{array}$ & $\begin{array}{c}\text { 107/160 (66.8\%); } \\
\text { CagA+: } 43 \\
(40.1 \%)\end{array}$ & $\begin{array}{l}\text { Yes, if CagA+; } \\
\text { increased levels of } \\
\text { urinary cross-laps }\end{array}$ \\
\hline Ozdem S, 2007 [105], Turkey & $61,36 / 25$ & $\begin{array}{r}11.8 \pm 3(\mathrm{~F}) \\
10.1 \pm 3(\mathrm{M})\end{array}$ & RUT, histology & & $\begin{array}{c}\text { Serum } \\
\text { P1NP, } \beta C T X, O C, \text { ALP, } \\
\text { PTH, Ca, } \text { PO }_{4}\end{array}$ & & & No \\
\hline Kakehasi A, 2007 [107], Brazil & $50, \mathrm{~F}$ & $61.7 \pm 7(50-70)$ & $\begin{array}{l}\text { RUT, histology, } \\
{ }^{13} \text { C-UBT }\end{array}$ & & DEXA, LS & $\begin{array}{l}10 / 18 \\
(55 \%)\end{array}$ & $\begin{array}{l}24 / 32 \\
(75 \%)\end{array}$ & No \\
\hline Kakehasi A, 2009 [108], Brazil & $85, \mathrm{~F}$ & $\begin{array}{c}63.7 \pm 7.3 \\
(\mathrm{HPI}+) \\
62.5 \pm 7.0 \\
(\mathrm{HPI}-)\end{array}$ & $\begin{array}{l}\text { RUT, histology, } \\
{ }^{13} \text { C-UBT }\end{array}$ & & DEXA, LS, H & & & No \\
\hline Figura N, 2010 [99], Italy & $1118,935 / 183$ & $\begin{array}{l}62.5 \pm 6(\mathrm{~F}) \\
65.9 \pm 6(\mathrm{M})\end{array}$ & Serum antibody & CagA & DEXA & $\begin{array}{c}41.5 \% \\
\text { CagA }+30 \%\end{array}$ & $\begin{array}{c}43.9 \% \\
\text { CagA }+21 \%\end{array}$ & Yes, if CagA+ \\
\hline Akkaya N, 2011 [109], Turkey & $105, \mathrm{~F}$ & $\begin{array}{l}65.3 \pm 6.1(\mathrm{OP}+) \\
63.6 \pm 6.5(\mathrm{OP}-)\end{array}$ & $\begin{array}{l}\text { Serum } \\
\text { antibodies }\end{array}$ & & DEXA, LS, H & $\begin{array}{l}41 / 58(\operatorname{IgG}+) \\
\quad(70.7 \%)\end{array}$ & $\begin{array}{l}35 / 47(\mathrm{IgG}+) \\
\quad(74.5 \%)\end{array}$ & No \\
\hline Asaoka D, 2014 [110], Japan & $200,105 / 95$ & $\begin{array}{c}62.8 \pm 7.7(\mathrm{M}) \\
63.4 \pm 9(\mathrm{~F})\end{array}$ & $\begin{array}{l}\text { Serum antibody, } \\
{ }^{13} \text { C-UBT }\end{array}$ & & $\begin{array}{c}\text { DEXA, LS; } \\
\text { serum bALP, NTX }\end{array}$ & $25 / 41(61.0 \%)$ & $\begin{array}{l}57 / 159 \\
(35.8 \%)\end{array}$ & $\begin{array}{c}\text { Yes, OR } 5.33 \\
(1.73-16.42) \text { in PUD }\end{array}$ \\
\hline Lin S, 2014 [111], Taiwan & $365, \mathrm{~F}$ & $77.3(65-97)$ & RUT, histology & & $\begin{array}{l}\text { DEXA or osteoporosis } \\
\text { medication use }\end{array}$ & $77 / 101(76.2 \%)$ & $\begin{array}{c}24 / 101 \\
(23.8 \%)\end{array}$ & $\begin{array}{c}\text { Yes, } \\
\text { OR 2.03 } \\
\text { (1.14-3.62) }\end{array}$ \\
\hline Asaoka D, 2015 [106], Japan & $\begin{array}{c}255, \\
135 / 120\end{array}$ & $63.2 \pm 8.5$ & $\begin{array}{l}\text { Serum antibody, } \\
{ }^{13} \text { C-UBT }\end{array}$ & & $\begin{array}{l}\text { DEXA, LS; serum bALP, } \\
\text { NTX }\end{array}$ & $25 / 43(58.1 \%)$ & $69 / 212(32.5 \%)$ & $\begin{array}{l}\text { Yes, OR 3.0 } \\
(1.31-6.88)\end{array}$ \\
\hline Mizuro S, 2015 [112], Japan & 230, M & $\begin{array}{c}>50 ; 62.1 \pm 5.0 \\
(\mathrm{TBD} \text { low) } \\
58.4 \pm 5.4 \\
(\mathrm{TBD} \text { normal })\end{array}$ & Serum antibody & & QUS, radius & $61 / 116(52.5 \%)$ & $38 / 114(33.3 \%)$ & $\begin{array}{l}\text { Yes, OR } 1.83 \\
(1.04-3.21)\end{array}$ \\
\hline $\begin{array}{l}\text { Fotouk-Kiai M, } 2015 \text { [113], } \\
\text { Iran }\end{array}$ & $\begin{array}{c}967,392 / 575 \\
\text { H.p. }+758 \\
\text { H.p. }-209 \\
\text { (controls) }\end{array}$ & $\begin{array}{l}68.3 \pm 6.8 \\
(\text { H.p. }+) \\
69.3 \pm 7.4 \\
(\text { H.p. }-)\end{array}$ & Serum antibody & & DEXA, LS, FN & $236 / 758(31.1 \%)$ & $\begin{array}{l}522 / 758 \\
(68.9 \%)\end{array}$ & $\begin{array}{l}\text { No, OR } 0.76 \\
(0.55-1.05)\end{array}$ \\
\hline
\end{tabular}


Table 1. Cont

\begin{tabular}{|c|c|c|c|c|c|c|c|c|}
\hline $\begin{array}{l}\text { First Author, Year, } \\
\text { Reference No, } \\
\text { Country/Region }\end{array}$ & $\begin{array}{l}\text { Population, } \\
\text { Gender } \\
\text { (F/M) }\end{array}$ & $\begin{array}{l}\text { Mean Age, } \\
\text { Years }\end{array}$ & $\begin{array}{l}\text { HPI Detection } \\
\text { Method }\end{array}$ & $\begin{array}{l}\text { HPI Strain } \\
\text { Identification }\end{array}$ & $\begin{array}{l}\text { Bone Status } \\
\text { Assessment Methods, } \\
\text { Skeletal Location }\end{array}$ & $\underset{(\%)}{\mathrm{HPI}+\text { and OP, }} n$ & $\begin{array}{l}\text { HPI+ and Non } \\
\text {-OP/Controls }\end{array}$ & $\begin{array}{l}\text { Association } \\
\text { (Yes/No) }\end{array}$ \\
\hline Chung Y, 2015 [97], Korea & $\begin{array}{l}\text { I, } 126, \mathrm{M} \\
\text { H.p. }+657 \\
\text { H.p. }-469\end{array}$ & $\begin{array}{c}54.4 \pm 10.7 \\
\text { (H.p. }+ \text { ) } \\
51.9 \pm 12.1 \\
\text { (H.p.-) }\end{array}$ & Serum antibody & & $\begin{array}{l}\text { DEXA, LS } \\
\text { (L1-L4) }\end{array}$ & $\begin{array}{c}173 * / 657 \\
(26.3 \%)(\mathrm{LS}) \\
114 / 657(17.4 \%) \\
\text { (FN) }\end{array}$ & $\begin{array}{c}484 / 657 \\
(73.7 \%)(\mathrm{LS}) ; \\
543 / 657 \\
(82.6)(\mathrm{FN}) \\
\end{array}$ & $\begin{array}{c}\text { Yes, only for lumbar } \\
\text { BMD (not for total } \\
\text { femur or femoral } \\
\text { neck) }\end{array}$ \\
\hline $\begin{array}{l}\text { Kalantarhormozi M, } \\
2016 \text { [96], Iran }\end{array}$ & $\begin{array}{l}\text { 250, F; } 16 \text { (OP), } \\
234 \text { (controls) }\end{array}$ & $58.9 \pm 8.0$ & Serum antibody & & $\begin{array}{c}\text { DEXA, LS, F; bone } \\
\text { turnover markers, OPG, } \\
\text { RANK, } \mathrm{Ca}, \mathrm{PO}_{4}\end{array}$ & & & No \\
\hline Shih H, 2016 [95], Taiwan & $\begin{array}{c}5447 \text { (H.p.+), } \\
21,788 \text { (controls) }\end{array}$ & $>20$ & $\begin{array}{l}\text { H.p. eradication } \\
\text { treatment for } \\
\text { PUD }\end{array}$ & & DEXA & & & $\begin{array}{l}\text { Yes, HR 1.62 } \\
(1.06-2.47)\end{array}$ \\
\hline Chen L, 2017 [114], Taiwan & $2689,1792 / 897$ & $>40$ & ${ }^{13} \mathrm{C}-\mathrm{UBT}$ & & $\begin{array}{c}\text { FRAX } \\
\text { (without BMD) }\end{array}$ & $\begin{array}{c}\text { F: } 177 / 324 \uparrow \\
\text { (54.6\%); } \\
\text { M: } 54 / 93 \\
(58.1 \%)\end{array}$ & & $\begin{array}{l}\text { No, for 10-year } \\
\text { fracture risk } \\
\text { prediction }\end{array}$ \\
\hline Chinda D, 2017 [115], Japan & 473 F (healthy) & $52.2 \pm 15.2$ & $\begin{array}{l}\text { Serum antibody } \\
\text { (IgG), H.p. } \\
\text { antigen in stool } \\
\text { sample }\end{array}$ & & QUS, calcaneus & $65 * / 118(55.1 \%)$ & $53 / 118(44.9 \%)$ & $\begin{array}{l}\text { No, OR } 0.95 \\
(0.55-1.63) \text { for } \\
\text { osteopenia }\end{array}$ \\
\hline Abdolahi N, 2017 [116], Iran & $\begin{array}{l}107 \mathrm{~F}, \\
34 \text { with OP, } \\
73 \text { controls }\end{array}$ & $\begin{array}{c}\text { Post- } \\
\text { menopausal }\end{array}$ & $\begin{array}{c}\text { Serum } \\
\text { antibodies (IgA, } \\
\operatorname{IgG)}\end{array}$ & & & $\begin{array}{l}70.6 \% \mathrm{IgA}+ \\
82.0 \% \mathrm{IgG}+\end{array}$ & $\begin{array}{l}54.8 \% \mathrm{IgA}+ \\
75.3 \% \mathrm{IgG}+\end{array}$ & No \\
\hline Lu L, 2018 [19], China & $1867,393 / 1474$ & & ${ }^{13} \mathrm{C}-\mathrm{UBT}$ & & QUS, calcaneus & & & No, for BMD \\
\hline $\begin{array}{l}\text { Pan B, } 2018 \text { [117], } \\
\text { Taiwan }\end{array}$ & $867,299 / 568$ & $55.9 \pm 11.3$ & RUT & & DEXA & $257 / 556(46.2 \%)$ & $124 / 311(39.9 \%)$ & $\begin{array}{c}\text { Yes, OR 1.62, } \\
(1.12-2.35) \text { for } \\
\text { decreased BMD }\end{array}$ \\
\hline Chinda D, 2019 [118], Japan & 268 M (healthy) & $49.1 \pm 15.1$ & $\begin{array}{l}\text { Serum antibody } \\
\text { (IgG), H.p. } \\
\text { antigen in stool } \\
\text { sample, serum } \\
\text { pepsinogens }\end{array}$ & & QUS, calcaneus & & & $\begin{array}{c}\text { No, OR } 1.31 \\
(0.54-3.21) \text { for } \\
\text { atrophic gastritis, } \\
\text { OR 0.74 (0.29-1.90) } \\
\text { without gastritis }\end{array}$ \\
\hline \multicolumn{9}{|c|}{ 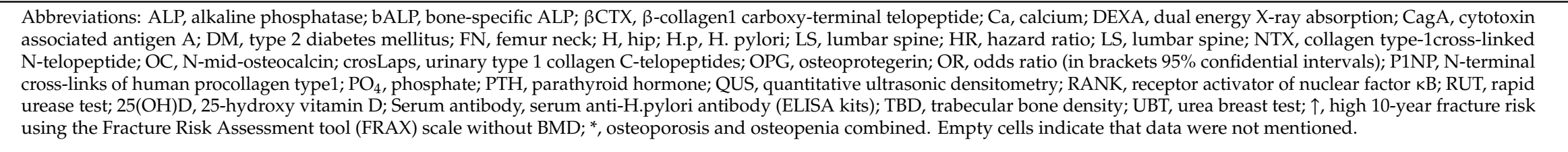 } \\
\hline
\end{tabular}


To summarize, the published results, though mixed, emphasize the possible role of HPI, particularly with cagA+ strains, in OP and fractures. A positive correlation between presence of HPI and OP has been observed in Western populations infected with H.p. strains containing cagA and in 7 of 11 studies from Eastern countries where near $100 \%$ of H.p. strains possess cagA. These observations indicate a possible strain-specific association between HPI and OP: the odds of OP in patients with HPI appear to be about twice as great in those infected with cagA+ strains. Moreover, a potentially preventive effect of HPI eradication has also been reported. However, because of the mentioned above methodological weaknesses of the available studies an accurate and reliable conclusion on causal relationships could not be made.

\section{HPI-Induced Upper Gut Diseases and Osteoporotic Fractures}

Another important piece of information on the HPI-OP/OF relationship could be expected from data regarding HPI-associated chronic diseases, many of which as well as the medications used are known to have deleterious effects on bone metabolism and/or increase risk of falls contributing to OFs. In the following sections, we summarize the available information on potential links between chronic HPI-related gastroduodenal and extra-digestive tract diseases and OP/OFs.

Although only a small fraction of patients with HPI develop peptic ulcer disease (PUD), chronic/atrophic gastritis and malignancies, these diseases are common worldwide, and HPI is the most important etiological and pathogenic factor for their development. These disorders and/or concomitant treatment have been reported to be associated with $\mathrm{OP} / \mathrm{OF}$.

\subsection{Peptic Ulcer Disease}

HPI is responsible for $95 \%$ of duodenal ulcers and $85 \%$ of gastric ulcers which usually arise at the junction of the antral and corpus mucosa. At least eight studies showed that PUD is an independent risk factor (RF) for OF [110,119-125]. History of PUD has been found to be associated with an increased risk of osteoporotic thoracic vertebral fracture in a large population sample of Finnish men $(n=30,000)$ but not in the women [119]. In a Polish study of 240 females [120], women with PUD ( $n=143$, mean age 60.3 years) not using hormone replacement therapy (HRT) had lower BMD in all studied regions as compared to controls without PUD ( $n=120$, mean age 58.4 years); moreover, among HRT users, the BMD in lumbar vertebrae and Ward's triangle was also significantly lower in women with PUD, whereas calcium intake was similar in both groups. Two reports from USA demonstrated an association between PUD and periprosthetic fractures after total hip replacement $(n=14,065$; hazard ratio (HR) 1.5, 95\% CI 1.1-2.2) [122] and total knee arthroplasty ( $n=17,633$; HR 1.87, 95\% CI 1.28-2.75) [121]. In the Japanese study ( $n=200,105$ women), multivariate analysis revealed that PUD (OR 4.98; 95\% CI 1.51-16.45), along with HPI (OR 5.33; 95\% CI 1.73-16.42) as well as common RFs (age, female gender, BMI), was independently related to OP [110]. A population-based study from Taiwan [123], which included 27,132 patients (aged $\geq 18$ years) diagnosed with PUD and 27,132 randomly selected subjects (age- and gender-matched) without PUD, found that the OP risk (adjusted for covariates) was 1.85 times greater in the PUD group (13.99 vs. 5.80 per 1000 person-years). The highest risk was observed one year after PUD diagnosis (HR 63.4, 95\% CI 28.2-142.7); use of a PPI significantly increased the OP risk (HR 1.17, 95\% CI 1.03-1.34). Consistent with these data are results from two most recent large South Korean studies [124,125]. In the first prospective study $(n=10,030)$, PUD patients demonstrated a significantly higher OP risk (men: HR 1.72, 95\% CI 1.02-2.92; women: HR 1.62, 95\% CI 1.20-2.18); OP developed in 29.9\% women and $11.1 \%$ men with PUD vs. $16.5 \%$ and $4.8 \%$ in controls, respectively [124]. The second report [125], based on analysis of 50,002 patients with PUD and equal number of controls matched by age, gender, past medical history, income and residence region, found increased risk of OP in PUD regardless of gender (adjusted HR 1.36, 95\% CI 1.33-1.40). In contrast, a retrospective cross-sectional study from China $(n=867$, with PUD 351 patient) reported that PUD was significantly associated with decreased BMD only in univariate analysis (OR 1.37, 95\% CI 1.03-1.82) [117]. Lastly, in a cohort of patients operated for PUD between 1956 and 1985 (pre-HPI era) 
and followed for 30 years, the risk of OF was significantly (and independently of surgical procedure type) increased showing a standardized incidence ratio of 2.5 for the proximal femur, 4.7 for vertebra and 2.2 for the distal forearm [126].

Although these reports, as any observational study, cannot indicate causality, the relationship between PUD and fragility fractures is suggested. It appears that PUD may approximately double the risk of $\mathrm{OP} / \mathrm{OF}$.

\subsection{Chronic/Atrophic Gastritis}

It is well established that HPI is responsible for the majority ( $>90 \%)$ of chronic/atrophic gastritis [127,128] and plays an important role in the initiation of autoimmune atrophic gastritis [128-130]; the latter occurs in $2 \%$ of the general population with a higher prevalence in older (>60 years) females [131]. CagA+ H.p., especially the East-Asian type, compared to the CagAtype induces more severe gastritis and mucosal atrophy and is more closely associated with gastric cancer [132]. Simultaneous presence of the CagA and other virulence factors (VacA, Helicobacter cysteine-rich protein $C$ and the chaperonin Gro) increases the risk of chronic atrophic gastritis (a precursor lesion to gastric cancer) 18-fold [133].

Two publications by a Brazilian group reported that in postmenopausal women neither HPI, no atrophic chronic gastritis were associated with BMD or OP $[107,108]$. No association between HPI-induced chronic gastritis and OP was also observed in an Iranian study [134]. In contrast, a Norwegian study [135] found that, in patients with chronic atrophic gastritis, compared to sex- and age-matched controls, bone formation markers (OC, sclerostin, OPG and OPG/RANKL ratio) were lower and the incidence of OP was higher (the latter abnormality only in males). In older Korean women, presence of atrophic gastritis was significantly linked to OP after adjusting for seven variables including age, BMI, metabolic and lifestyle variables (OR 1.89, 95\% CI 1.15-3.11) [136]. Similarly, Japanese men with HPI-induced atrophic gastritis (defined by serum pepsinogen I and pepsinogen II levels) demonstrated an increased risk of low trabecular bone density (OR 1.83, 95\% CI 1.04-3.2) [112]. In a small Norwegian study ( $n=17$ patients, 41 controls), subjects with chronic atrophic gastritis, compared to controls, have: decreased circulating levels of OC (bone formation marker), sclerostin (an inhibitor of bone formation), osteoprotegerin (OPG) and OPG/RANKL ratio; unaffected levels of P1NP (bone formation marker) and bCTX (bone resorption marker); and (in males only) lower lumbar BMD and increased frequency of osteopenia and OP. No difference in bone quality assessed by microidentation was found [135]. These features were interpreted as suggestive of decreased bone formation and higher bone resorption in patients with chronic atrophic gastritis. A study from Germany reported that OP development was associated with gastritis/duodenitis (OR 1.14; $p=0.045)$ and PPI use [137]. A retrospective cohort study of Korean premenopausal women in their 40s $(n=983)$ who had undergone a 48-month follow-up assessment of BMD of L1-4 showed that atrophic gastritis (diagnosed by gastroduodenoscopy) was significantly associated with bone loss (adjusted for confounding factors); patients with persistent atrophic gastritis exhibited a greater decrease in BMD and the prolonged duration of the disease correlated positively with the amount of BMD reduction [138]. Atrophic gastritis and CagA seropositivity were associated with lower hemoglobin levels, and anemia was 2.6-times (in women) and 1.5-times (in men) more common among persons with atrophic gastritis [139]. Severe hypochlorhydria or achlorhydria were found in $44 \%$ of patients with idiopathic iron deficient anemia and in $1.8 \%$ among healthy controls [140].

Molecular mimicry between H.p. antigens and gastric H/K-ATPase has been proposed as a mechanism responsible for the association between HPI and development of chronic atrophic autoimmune gastritis $[127,130,141-144]$. In $20-30 \%$ of patients with HPI, autoantibodies to the $\mathrm{H} / \mathrm{K}$-ATPase were identified. In this organ-specific autoimmune disorder, autoantibodies to gastric parietal cells (in $90 \%$ of patients) and intrinsic factor (in $70 \%$ of patients) cause gastric gland atrophy, achlorhydria and hypergastrinemia (which induces hyperplasia of the ECL cells) resulting in vitamin B12 and iron malabsorption/deficiency and leading to megaloblastic/pernicious anemia and/or iron-deficient 
anemia, respectively [145-150]. The disease is clinically heterogeneous and may have an asymptomatic course. An inverse correlation between H.p. density and vitamin B12 levels has been shown [151]. Low serum B12 levels affect DNA synthesis, an important factor for bone remodeling. Vitamin B12 (and other B vitamins-B2, B6 and folate-linked to homocysteine metabolism) is regarded an essential factor for bone health $[117,152-161]$. Vitamin B12 deficiency was reported to have an increased fracture risk: 1.7- to [162] 1.9-fold [163] for hip fracture, 1.8-fold for vertebral fracture [163] and 2.9-fold for distal forearm fracture [163]. Peripheral neuropathy, occurring in vitamin B12 deficient patients [164], undoubtedly, increases risk of falls. Reversal of severe OP associated with pernicious anemia has been demonstrated after vitamin B12 replacement combined with etidronate (an antiresorptive bisphosphonate) therapy [165]. Repletion of B12 resulted in an $80 \%$ reduction in hip fracture risk among stroke patients [155]. However, recent trials and a meta-analysis did not show a preventive effect of treatment with vitamin B12 and folic acid on fracture risk [166]. Daily supplementation with $B$ vitamins did not affect markers of bone turnover and did not reduce fracture risk in middle-aged and older women at high risk of cardiovascular disease [167]. Interestingly, a significantly increased hip fracture risk persists years after correction the vitamin B12 deficiency, indicating the independent pathophysiological importance of chronic atrophic gastritis and achlorhydria [162]. Chronic atrophic autoimmune gastritis is associated with multiple other nutritional deficiencies, including calcium, vitamins D, C and folic acid, each of which may affect the skeletal, nervous and hematological systems $[149,157,168]$. In addition, autoimmune gastritis clusters with autoimmune thyroiditis and type 1 diabetes mellitus $[128,130]$, conditions linked to OP/OF. Iron deficiency with or without anemia has also been recognized as a RF for OP/OFs in many [169-176] but not all $[177,178]$ studies (the topic is discussed in following sections).

Importantly, pharmacologic HPI eradication results in gradual and significant improvement in chronic atrophic gastritis [179-181]. On the other hand, when interpreting the studies on HPI-induced chronic/atrophic corpus gastritis, it has to be kept in mind that with progression of the severity and extension of atrophic lesions H.p. is spontaneously eradicated [143,182,183].

In conclusion, findings in patients with HPI-induced (especially with cagA+ strains) chronic/atrophic gastritis suggest that gastric corpus structural and functional (e.g., hypoacidity, hormonal disbalance, etc.) changes and associated nutritional deficiencies may negatively affect bone metabolism, neuromuscular and a wide range of other functions predisposing to OP, falls and OFs.

\subsection{Gastric Cancer}

HPI is an important determinant of neoplastic gastric lesions classified by WHO/IARC [184] as class 1 human carcinogen for non-cardia gastric adenocarcinomas [185-187]. HPI increases the cancer risk 5.8-7.9-fold [185,188], and the risk is 2-3-times higher in subjects infected with cagA+ strains [186,189-191].

According to most but not all studies [192,193], gastric cancer survivors who underwent gastrectomy, compared to the general population [194-204] or age- and sex-matched healthy controls [205-208], have significantly lower BMD, higher prevalence of osteopenia/OP (38.3\% [196] to 55\% [203]) and higher fracture rates (approximately 40\% [196,200,205]). Bone loss (although of a lesser degree) was also reported in gastric cancer survivors after endoscopic tumor resection undertaken in early stage [202]. In South Korea, nationwide cohort study of cancer survivors who underwent gastrectomy ( $n=133,179$ matched to non-cancer controls, 1:1) demonstrated an increased risk of fractures (HR 1.61; 95\% CI 1.53-1.70), which was higher in patients after total gastrectomy (HR 2.18; 95\% CI 1.96-2.44) and adjuvant chemotherapy (HR 2.01; 95\% CI 1.81-2.23); the elevated OF risk was significantly associated with anemia [208]. In a report from Japan, the adjusted hazard ratio for OF in men after gastrectomy $(n=132)$ was $2.55(95 \%$ CI 1.17-5.55) and $3.56(95 \%$ CI 1.33-9.52) in those who survived $>20$ years [209].

A considerable amount of OFs after gastrectomy occurs in the early postoperative period [200,203]. Bone remodeling imbalance with disproportionately increased bone resorption [197,199], decreased 
BMD [210] and higher fracture rates [200] were often observed during the first postoperative year. Altered bone metabolism was reflected by increased serum concentrations of bone resorption markers (C-terminal telopeptides of type I collagen, deoxypyridinoline and pyridinoline) [199], elevated serum PTH and alkaline phosphatase (ALP) levels [197,210] and associated with vitamin D deficiency [210-214]. Some researchers, however, observed no changes in BMD, a slight elevation of OC and only minor increase in PTH levels after total gastrectomy [192]. The causes of OP and subsequent fractures in patients with gastric cancer are multifactorial. Malabsorption (especially of calcium, phosphate, iron, proteins, vitamins B12 and D), malnutrition, weight loss, use of certain medications (e.g., fluorouracil and cisplatin which induce apoptosis of osteoblasts and increase osteoclast activity [215-217], hormones, radiotherapy, comorbidities, physical inactivity, old age and smoking-all were documented as factors contributing to bone loss and OFs in gastric cancer patients [198,200,202,203,214,217,218].

It is well established that HPI eradication reduces the incidence of gastric cancer [219-222] and favors regression of the low-grade B-cell gastric MALT [223].

\subsection{Gastroesophageal Reflux Disease (GERD)}

HPI does not influence the function of the lower esophageal sphincter, the motility of the esophagus and the esophageal acid exposure. HPI might protect the distal esophagus (possibly an evolutionary adaptation [9]) by causing atrophy of the fundal gastric glands and hypochlorhydria, especially in subjects with cagA+, vacA+ strains and pro-inflammatory genotypes (IL-1 $\beta$ and IL-1RN) [224-229]. Many studies, as would be expected, reported an inverse association between HPI-induced corpus gastritis and GERD, its severity, prevalence of Barrett's esophagus (BO) and esophageal adenocarcinoma $[9,137,230-238]$. The strongest relationship was observed in East Asian populations [229,237]. A meta-analysis of 72 studies $(84,717$ patients with $\mathrm{BO}$ and 390,749 controls) found that HPI reduces the risk of $\mathrm{BO}$ by $32 \%$ (OR 0.68, 95\% CI 0.58-0.79) [237]. Six meta-analyses on association of HPI and esophageal adenocarcinoma indicated an inverse relationship [238], whereas a recent meta-analysis (35 studies including 345,886 patients) did not find such association, except the Middle East data [239]. Other researchers concluded that presence of HPI might aggravate GERD [240], or, at least, is not "protective" against GERD, as the incidence of GERD and its sequelae in patients with HPI is higher than that after eradication of the infection [241,242], HPI eradication improves GERD symptoms and esophagitis [243-247] and does not increase the risk of BO [248-250]. Meta-analyses on effect of eradication HPI produced, however, inconsistent results [229]: a significantly higher risk of developing de novo GERD was demonstrated in Asian studies [251], but not in Western ones [252-254]. In a recent retrospective large cohort study from US ( $n=36,803$ patients with HPI), rates of esophageal and proximal gastric cancers 5, 10 and 15 years after treatment/eradication of HPI were low- $0.15 \%$, $0.26 \%$ and $0.34 \%$, respectively [255]. In the interpretation of the data on the relationship between HPI and GERD the type and location of HPI-induced gastritis should be taken into account. As the level of gastric acid secretion is the main pathophysiological factor in GERD, chronic atrophic corpus gastritis causing hypo-/achlorhydria may exert a "protective" effect, while antrum gastritis with hyperchlorhydria can play an opposite role, and, not unexpectedly, HPI eradication may differently affect outcomes.

Several studies reported an association between GERD and vertebral fractures or kyphosis [256-258]. The most recent publications, however, did not confirm that GERD and decreased BMD are linked [117], neither that the incidence of OFs is higher among subjects with BO [259] (Kumar S 2017). As in the total population, older age, female gender and a higher comorbidity index were the independent risk factors for OFs in patients with BO. In the BO cohort, PPI therapy even prolonged and in high-doses, was not associated with increased fracture risk (HR 0.89; 95\% CI 0.12-6.55), although a predisposition (numerically but non-significantly) for osteoporotic hip and vertebral fractures was observed [259].

The Maastricht IV/Florence Consensus Report on the management of HPI acknowledges that GERD is less common amongst those who are infected, but concludes that eradication of H.p. does 
not influence the severity of GERD [260]. In patients with GERD, according to Italian guidelines [261] and other recommendations [247], HPI can be eradicated.

\subsection{Effects of Acid-Suppressive Drugs}

Since gastric acid-lowering drugs (proton pump inhibitors (PPIs) or histamine-2 receptor antagonists (H2Rs)) are prescribed routinely in HPI-induced diseases (the "gold standard" therapy in acid-related disorders) and widely used in many other disorders (GERD, BO, prevention of aspirinand NSAID-induced upper gastrointestinal bleeding, etc.), clarification of their effect on OP/OF is important. The topic remains a matter of debate. A positive, albeit modest, association between PPIs and OP was reported in animal [262-264] and numerous of human studies. Many studies and meta-analyses suggested that acid inhibitors, especially the PPIs, moderately increase risk of fractures, particularly in older adults (who are already at higher fracture risk); the risk increases with longer durations of PPI use, often only in the presence of at least one other RF for OP such as older age, female gender and a higher comorbidity score [265-290]. Moreover, use of PPIs may also increase risk of falls [291-293]. These associations, however, have not been confirmed in a number of longitudinal studies and reviews [259,280,294-309]; even a modest reduction in fracture risk with PPI use has been reported $[307,310]$. Some researchers who are not supporting the association of PPI therapy with BMD recognize, nevertheless, that in PPI users the risk of fractures and falls could be higher $[311,312]$ as the unadjusted HR was significantly elevated (1.36, 95\% CI 1.19-1.55).

In a recently published meta-analysis [313] which included 33 studies $(n=2,714,502)$, subjects taking PPIs demonstrated a significantly increased overall fracture incidence $(22.04 \%$ vs. $15.57 \%$ in controls) with pooling OR of 1.28 (95\% CI 1.22-1.35); fracture risk raised with duration of PPI use (OR 1.29 in short users and 1.62 in long users), but no effect on BMD was found. Similar results were obtained in another meta-analysis [289]: PPI users, compared to non-users, had an increased risk of developing spine fracture (HR 1.49; 95\% CI 1.31-1.68), hip fracture (HR 1.22; 95\% CI 1.15-1.31), any-site fracture (HR 1.30; 95\% CI 1.16-1.45) and OP (HR 1.23; 95\% CI 1.06-1.42), but there was no correlation with BMD loss neither in the spine, nor in the hip. According to the latest meta-analysis (24 observational studies with 2,103,800 participants, 319,568 hip fracture patients), risk of hip fracture increased significantly in PPI users (RR 1.20, 95\% CI 1.14-1.28), and the association was observed even in subjects taken low doses of PPI [314].

It is noteworthy that in patients with chronic diseases, long term PPIs use may also contribute to muscle alterations such as muscle wasting, function loss and sarcopenia [315], which have been explained by nutrient deficiencies (magnesium, vitamin D) and gut dysbiosis related to acid suppression.

Regarding the effects of H2RA, most investigators observed little influence on BMD even in long-term (>5 years) users [268,269,279,290,301,314], but some researchers found lower BMD (if calcium intake was reduced) [316] and an increased hip fracture risk with high doses [276].

When interpreting the above mentioned controversial reports it should be acknowledged that an overlap between HPI status and using PPIs or H2RAs are important but often unrecognized confounders; in most of these studies the effects of other potential confounders (comorbidities, risk of falling, calcium and vitamin D supplementation, use of osteoporotic drugs, lifestyle factors, physical activity, etc.) have rarely been taken into account.

There is no general consensus on the clinical significance of possible detrimental effects of gastric acid-lowering drugs on the bone metabolism, BMD, falls and OFs. The acid-suppressive medications have been considered as a factor contributing to OFs by the American National Osteoporosis Foundation [317,318], while the American Gastroenterological Association (AGA) did not recommend routine screening or monitoring of BMD in PPI users [280].

No randomized controlled studies on the topic have been published until 2019. The first randomized, double-blind, placebo-controlled trial [319] that assessed in 115 healthy postmenopausal women (mean age 62 years) skeletal effects of 26 week treatment with a PPI found small but significant increases in circulating bone turnover markers: P1NP ( $+18.2 \%$ on esomeprazole $40 \mathrm{mg} /$ day and $+19.2 \%$ 
on dexlansoprazole $60 \mathrm{mg} /$ day) and CTX $(+22.0 \%$ and $+27.4 \%$, respectively); no statistically significant changes in serum PTH, fractional calcium absorption, as well as in urine levels of minerals and-most importantly-no impact on areal BMD in the lumbar spine, total hip, or femoral neck were observed. A large randomized double-blind trial of patients $(n=17,598)$ receiving pantoprazole $(n=8791)$ or placebo $(n=8807)$, rivaroxaban alone, rivaroxaban with aspirin, or only aspirin demonstrated that three years of PPI use was associated only with an excess of enteric infections but not with fractures or other previously reported adverse events (cardiovascular, pneumonias) [320]. In these two randomized studies the HPI status, unfortunately, has not been mentioned/evaluated.

When balancing the risks and benefits of long-term using PPIs it should be taken into consideration that several studies reported a significant relationship between the risk of gastric cancer and long-term use of PPIs [321-329]. In a recent large population-based study $(n=63,000$, median follow-up of 7.6 years) a dose- and duration-dependent relationship between long-term use of PPIs and gastric cancer development, even after successful eradication of H.p., has been shown (HR 2.44, 95\% CI 1.42-4.20) [325]. A meta-analysis of reports on 926386 participants obtained similar results [328]. At the same time experimental studies demonstrated that PPIs increase the effectiveness of chemotherapy for gastric cancer and might play a "dual role" in gastric carcinogenesis and its management [330].

To summarize, although the two randomized controlled studies did not find an association between PPI therapy and OP/OF, the potential risk of chronic PPI use for OF (and other adverse effects) observed in many previous studies and shown again in recent meta-analyses should not be neglected, particularly in persons with an elevated risk for OP and/or falls in whom the indications and the benefit/harm ratio should be carefully evaluated and lowest doses of PPIs for the shortest duration need to be prescribed.

\section{HPI-Associated Chronic Extra-Gastroduodenal Diseases, Medication Use and Osteoporotic Fractures}

HPI is one of few conditions that, aside from the common upper gut diseases, present high degree of concomitance with numerous extra-gastroduodenal disorders. A possible association between HPI and over 50 systemic diseases has been described. In recent years numerous reviews focused on this topic $[11,13,14,68,79,331-346]$. Most of HPI-linked extra-gastroduodenal chronic diseases and disorders as well as treatments used for are known to increase risk of OP, falls and OFs, especially in the elderly [317,347-349]. More than $80 \%$ of patients with a clinical vertebral or non-vertebral fracture suffer at least one chronic disease, and in $65.5 \%$ of these patients at least one bone- and/or fall-related RF was found [350]. Although the morbidity associated with OP is primarily due to fragility fractures, the factors contributing to OP and falls often are studied separately and the potential combined impact of HPI on these two main and equally important components of OFs remains largely unknown. There is no comprehensive synthesis of the data on involvement HPI in these processes. HPI-associated diseases are currently not recognized as RFs for OP/OF and HPI treatment is not integrated in prevention strategies.

\subsection{Chronic Extra-Gastroduodenal Diseases}

The presence of chronic diseases and use of medications that have deleterious effects on bone metabolism resulting in low bone mass, microarchitectural alterations and leading to fragility fractures are usually defined as RFs for "secondary" OP (in contrast to "primary" OP which is age-related and occurs in post-menopausal women and in men in the absence of an underlying disease) [351-359].

The main HPI-related chronic extra-gastroduodenal diseases and disorders relevant (but not all firmly established) concerning OP, falls and OF are listed in Table 2. To date, solid data support the etiological role of HPI in few disorders. In addition to the gastroduodenal diseases (described in the previous section), only hematological disorders-iron deficiency, vitamin B12 deficiency and immune thrombocytopenia (ITP)—are included in the international consensus (Maastricht $\mathrm{V} /$ Florence) and management guidelines recommend eradication of the pathogen [360]. Although 
many studies reported that HPI was associated with an approximately two-fold increased risk of development of other chronic extra-gastroduodenal diseases listed in Table 2, the topic remains controversial. Among 13 autoimmune diseases evidence in support of a probable role of HPI was found in four-TP, Graves' disease, neuromyelitis optica and psoriasis [361]. Just to mention some examples of contradictory conclusions: many reports and meta-analyses suggested a positive correlation between HPI, metabolic associated fatty liver disease (MAFLD; previous term non-alcoholic fatty liver disease, NAFLD) [362-372], type 2 diabetes mellitus (DM)/insulin resistance [373-377], diabetic complications [378-380] and obesity [381,382], whereas others did not found such associations [383-389] and some described an inverse correlation of HPI with obesity [390-392]. Similarly, there is discrepancy between various studies regarding links between HPI and cardiovascular diseases (CVD) [333,393-400]. However, a recent large cohort study demonstrated that HPI eradication (in patients $<65$ years old) was associated with a trend of decrease in coronary artery disease (CAD) occurrence and significantly lower mortality rate [399]. Although studies suggesting the influence of HPI on chronic extra-gastric diseases pathogenesis are accumulating, the available data do not allow unequivocal conclusions.

Table 2. HPI-related chronic extra-gastroduodenal diseases and disorders linked to osteoporotic fractures.

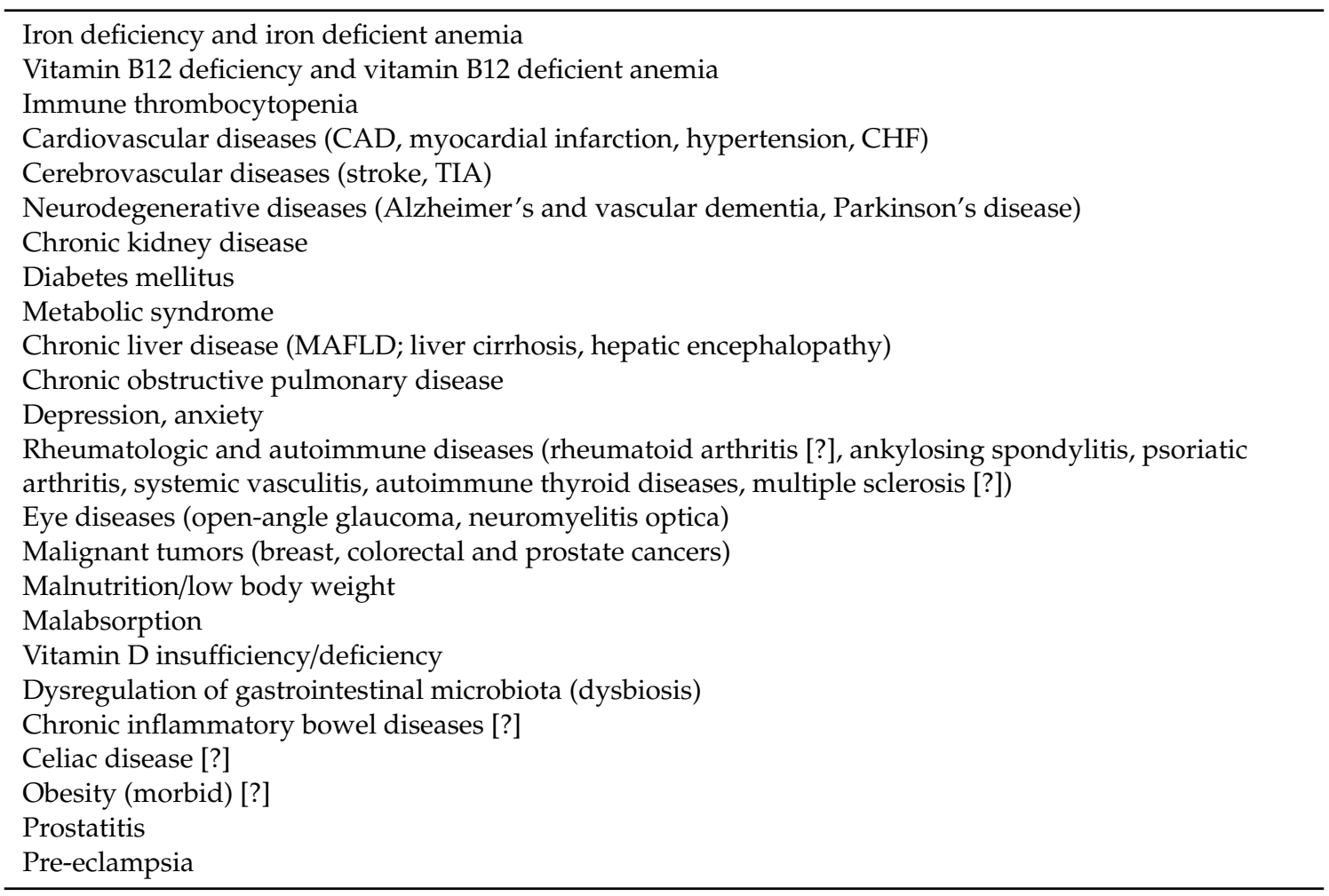

[?] Indicates that HPI according to some studies may protect against the disease. Abbreviations: $C A D$, coronary artery disease; CHF, congestive heart failure; MAFLD, metabolic associated fatty liver disease.

Notable, certain H.p. strain-specific virulence constituents, in particular cagA, are significantly associated not only with an increased risk of gastroduodenal diseases but also with a number of extra-intestinal disorders and diseases associated with OP/OF, including iron deficient anemia, ITP, acute coronary syndromes, serum dyslipidemia, Parkinson's disease, MAFLD, metabolic syndrome, DM, thyroiditis, liver cirrhosis and glaucoma. CagA activates major signaling pathways regulating bone remodeling (e.g., NF-kB, Wnt/beta-catenin, etc.) and alters various cellular responses involved in systemic inflammation, tissue homeostasis and function. Among diverse and complex pathophysiological mechanism through which H.p. cagA+ strains may cause extra-gastroduodenal disorders persistent systemic inflammation and molecular mimicry of CagA appear as most important. 
Recent data suggests that OP and a variety of HPI-associated chronic extra-gastroduodenal diseases share several RFs, many aspects of pathophysiology and are RFs for one another. The common RFs and pathogenic mechanisms include malnutrition, weight loss, low grade systemic inflammation, oxidative stress, vitamin D insufficiency/deficiency, lower socioeconomic status, behavioral and lifestyle characteristics (cigarette smoking, excess alcohol consumption, lower physical activity, air pollution). Comparison of the role of sex and age in OP/OF and in HPI is of interest. OP/OF affects more females in the older/postmenopausal age (the F:M ratio among hip fracture patients is 2:1 [401]) and the incidence of OFs increases exponentially with age $>70$ years in both genders [402-405], while males $<40$ years of age had higher fall rates [406]. Among adults, a small male predominance of HPI-related outcomes has been found in a meta-analysis based on 169 studies (OR 1.12, 95\% CI: 1.09, 1.15) [407]. Shared genetic basis underlying OP and a variety of HPI-related chronic extra-gastroduodenal diseases (CAD, DM, dyslipidemia) has been reported [408-419]. The shared biology and bi-(multi-)directional links between OP and HPI-associated chronic diseases apply particularly to CVD, CKD, CLD, DM and neurodegenerative diseases; these disorders are interrelated and often accompanied by OP/OF [420-430], and the risk of OP/OF increases when two or more HPI-associated chronic diseases are present.

On the other hand, it should be acknowledged that HPI may have a dual role of in human pathology. By affecting immune and inflammatory responses [78,92,431-433]. HPI may protect against asthma and allergy (particularly in children), autoimmune disorders (systemic lupus erythematosus, rheumatoid arthritis [RA] and multiple sclerosis, coeliac disease), inflammatory bowel disease (especially Crohn's disease), eosinophilic esophagitis, eczema, obesity [9,78,342,433-441] and tooth loss [442]. Negative associations between these diseases and HPI (beneficial effects) were observed mainly in patients colonized with cagA+ strains of H.p. The inverse correlations were interpreted as a reflection of evolutionary adaptation [9] and/or improved socioeconomic conditions, sanitation and widespread use of antimicrobials. However, the topic is still debated. HPI has been reported to increase the risk of adult-onset asthma [443] and systemic lupus erythematosus [444]. A significantly higher HPI incidence rate was found in patients with Sjogren syndrome [445], autoimmune thyroid disease [446-448], multiple sclerosis $[447,448]$ and no association between HPI and body mass index/obesity was observed in different populations $[388,449,450]$. The huge heterogeneity of asthma and other mentioned above diseases may, at least partially, contribute to the controversies in the publications.

\subsection{Falls}

Increasing evidence indicates that HPI may play a role in the complex and multifactorial nature of falls. Because OP is only part of the fracture equation, of particular importance is the fact that many mentioned above HPI-associated chronic diseases and their various combinations affect simultaneously (directly and/or indirectly) bone homeostasis and muscle mass/function, altering mobility, gait and balance, causing hemodynamic instability and collectively elevating the risk of falls and fractures, especially in the elderly [451-465]. It has been estimated that $87 \%$ of all fractures in the elderly are the result of a fall and 5-10\% of all falls result in a fracture [466-468]. Among 494,160 patients aged $\geq 50$ years with OP, $9 \%$ had only OP, while the rest had also chronic diseases, including CVD (54\%), $\operatorname{DM}(8 \%)$, depression $(4 \%)$, COPD $(1 \%)$, with two or more diseases in $24 \%$ [469]; the HPI status in this study has not been reported.

OF is usually a result of a low trauma fall in a person with frail bones (osteopenia/osteoporosis), but up to two-thirds of all fractures are not attributable to OP if the latter is defined by BMD measurement [470]. Although muscle atrophy and bone loss may occur simultaneously, bone fractures are often preceded by loss of muscle mass and strength. The endocrine functions of skeletal muscles [471-477], the tight bidirectional (patho) physiological muscle-bone cross-talk [142,209,478-492], and their shared genetics [493-496] are well recognized. Not surprisingly, RFs for OP and falls often coexist (up to $63 \%$ in patients with HF [497]). Osteosarcopenia (loss of lean body mass, bone and muscle), a major component of aging-related illnesses, especially those linked to chronic inflammatory state, is common in many HPI-associated diseases and disorders (congestive heart 
failure [CHF], CKD, COPD, DM, RA, stroke, dementia, malnutrition, altered vitamin and hormonal status) and increases with ageing [485,491,498-503]. Postural control is impaired in women with low BMD [504]. A recent meta-analysis ( 5 cohort studies, $n=27,990)$ demonstrated a significant positive association between sarcopenia and fracture (adjusted HR 1.50, 95\% CI 1.08-2.08) [505]. Increased falls and fracture risks were reported in patients with combination of sarcopenia and OP [483,506,507], but, surprisingly, a synergistic effect has not been observed in community-dwelling older men [508]. Noticeable, RFs for falls linked with HPI-related morbidity include, in addition to altered muscle status, impaired vision, hemodynamic instability (orthostatic and postprandial hypotension), arrhythmias, mental impairment, depression and anxiety $[457,466,468,509,510]$, as well as the numerous medications used. Strong associations between frailty and an increased propensity to falls, fractures and mortality are well documented [483,511-520]. A vicious cycle may occur: chronic HPI-associated diseases contribute to frailty which is a significant determinant of $\mathrm{OP} / \mathrm{OF}$ and disability/frailty further worsened after the fracture.

\subsection{Medications}

Among numerous drugs used for HPI-related diseases many are well known to contribute to $\mathrm{OP} / \mathrm{OFs}$. In regard to OP, these include corticosteroids, antidepressants (especially, selective serotonin- and serotonin-norepinephrine reuptake inhibitors), glitazones, opioids, benzodiazepines, antipsychotics, antiparkinsonian drugs, antiepileptics, PPIs, H2RA, thyroxine, furosemide, aromatase inhibitors, gonadotropin releasing hormone $(\mathrm{GnRH})$ agonists, whereas hormone replacement therapy with estrogen, thiazides, angiotensin-converting enzyme (ACE) inhibitors and angiotensin II receptor blockers (ARBs), spironolactone, beta-blockers, statins, antihistamines, metformin, sulphonylureas, glucagon-like peptide-1 receptor agonists (liraglutide) and nitrates have shown an osteoprotective effect [316,521-554].

The prevalence of suspected medication-related falls is about $41 \%$ [555] to $49 \%$ [556]. Increased risk of falls was documented in users of anxiolytics/hypnotics, opioids, sedatives, antihypertensives (especially alpha-blockers), antidepressants, antiparkinsonian medications, antiepileptics and antiarrhythmics [557-583]; polypharmacy is strongly associated with injurious falls and fractures [574,582,584-588].

Notable, some medications demonstrate opposite effects on bone metabolism and risk of falling. For instance, thiazide diuretics, beta-blockers, calcium-channel blockers and ACE inhibitors may contribute toward orthostatic hypotension, syncope and falls, but exert beneficial effect on mineral-bone metabolism and, paradoxically, may reduce fracture risk [547,552,589-598]. Some agents have shown divergent effects on bone and skeletal muscles. For example, thiazolidinediones demonstrate detrimental effect on the skeleton and increase fracture risk [545,599-604] but a beneficial effect on muscle atrophy [605]; other anti-diabetic drugs (sulfonylureas, metformin and possible incretin mimetics) have a neutral or a positive/protective effect on bone health, but they may increase propensity for falls through hypoglycemia (insulin and sulfonylureas) $[601,603,604,606]$. When analyzing the complex relationships between OFs and drugs used it should also be taken into account that many medications (corticosteroids, sulfonamides, urea derivatives, vitamin $\mathrm{K}$ antagonists, cardiac glycosides, loop diuretics, potassium-sparing diuretics, ACE inhibitors, serotonin reuptake inhibitors, calcium-channel blockers and antiepileptic drugs) may affect the vitamin D status and calcium homeostasis [607-611]. Importantly, even in diseases inversely associated with HPI the abovementioned drugs may contribute to OP and/or falls and should be used with caution, especially in individuals with high fracture risk. 
In other words, while the HPI-associated diseases and their complications may itself play an important role in $\mathrm{OP} / \mathrm{OF}$, certain concomitant treatment/medications may affect in the same or different way the skeleton, muscles and hemodynamic status, thereby modulating fracture risk. Prevention medication-related OP/OFs involves multifaceted concerns, and reviewing, ceasing, switching or dose reduction of prescribed drugs need to be considered. Obviously, the impact of each HPI-related disorder and the benefit/harm balance of drugs used should be evaluated in combination to determine an individualized preventive and therapeutic approach to OP/OF.

In closing this section, it worth mentioning that beneficial effects of HPI eradication include decreased occurrence and/or improvement across an array of chronic diseases and disorders associated with OP/OFs (e.g., iron deficiency/anemia, ITP, CAD, Parkinson's, endocrine, psoriasis, gut dysbiosis, chorioretinopathy, etc.). HPI eradication is accompanied by positive effects on energy homeostasis, mineral and bone metabolism, reduces risk of muscle wasting and improves bioavailability of different orally administered drugs.

To sum up, HPI-associated chronic diseases via complex and possible shared underlying pathophysiological and genetic mechanisms and treatment-related factors may affect the musculoskeletal and other extra-digestive systems and therefore increase the risk of falls and fractures and vice versa OP/OFs exacerbate the chronic illnesses. Considering that HPI may contribute, at least partially, to many diseases associated with secondary OP, which occurs in up to two thirds of men, more than half of pre- and peri-menopausal women and in 20-30\% of postmenopausal women [612-615], a heightened awareness of these relationships is important.

\section{Potential Pathophysiological Mechanisms}

A review and detailed discussion of multiple mechanisms underlying the potential association between HPI and OP/OFs is beyond the scope of the current manuscript, but a brief simplified re-count of most relevant factors might be useful. Proposed mechanisms and potential pathways linking numerous chronic HPI-associated diseases and disorders with $\mathrm{OP} / \mathrm{OFs}$ are complex and include interplay between HPI-induced changes in gastroduodenal mucosal structure and function causing multitude disturbances in different biochemical pathways and affecting many system organs. These effects are interrelated and can be grouped as follows: (1) local and systemic low-grade inflammation; (2) disturbances in mineral homeostasis (calcium, phosphate and magnesium); (3) alterations in hormonal status (gastric/gut production of ghrelin, somatostatin, gastrin, histamine, leptin, estrogens, serotonin and dopamine as well as secretion of systemic hormones-sex hormones, PTH, cortisol, etc.); (4) iron, vitamin B12 and folate deficiencies and anemia; (5) oxidative stress; (6) gut dysbiosis; (7) altered energy homeostasis; (8) H.p. antigenic mimicry (homologous sequences of some bacterial virulence peptides that mimic host proteins cause production of autoantibodies); and (9) drug-induced (influences of various medications used for HPI-induced diseases and HPI-related conditions). Notable, no single factor could account for HPI-associated OP/OFs. HPI induces a chain of events resulting in co-influence of alterations in multiple (physio-) pathological pathways which directly and indirectly affect the musculoskeletal system, gait, balance, hemodynamic stability, etc., compromising bone health and increasing risk of falling. Figure 2 summarizes the potential pathophysiological mechanisms linking HPI-related gastroduodenal and extra-digestive diseases and disorders with bone health, falls and OFs. 


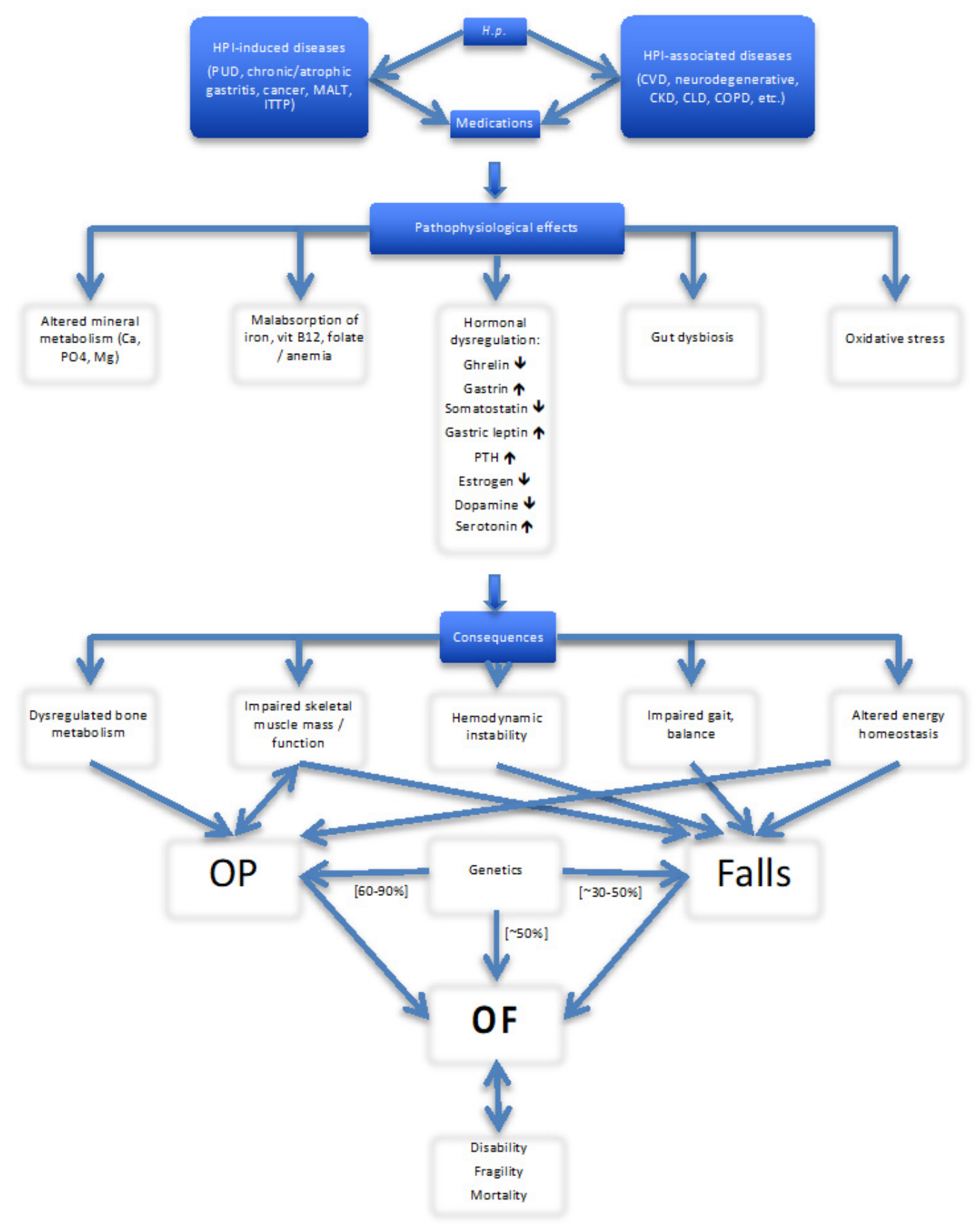

Figure 2. Schematic representation of Helicobacter pylori infection (HPI)-related factors and main pathophysiologic mechanisms that may lead to osteoporotic fractures. Abbreviations: Up-arrows refer to elevation/stimulation, down-arrows refer to reduction/decrease; Ca, calcium; CKD, chronic kidney disease; CLD, chronic liver disease; COPD, chronic obstructive pulmonary disease; CVD, cardiovascular disease; H.p., Helicobacter pylori; ITT, idiopathic thrombocytopenic purpura; MALT, mucosa-associated lymphoid tissue B-cell lymphoma; $\mathrm{Mg}$, magnesium; $\mathrm{OF}$, osteoporotic fracture; OP, osteoporosis; $\mathrm{PO}_{4}$, phosphate; PTH, parathyroid hormone; PUD, peptic ulcer disease. Notes: HPI- and concomitant treatment-induced changes in gastric structure and functions affect nutrient absorption (calcium, phosphate, magnesium, iron, vitamin B12, folate, etc.), production of gastric/gut (ghrelin, gastrin, histamine, somatostatin, leptin, estrogens, dopamine, serotonin and incretins) and systemic hormones (PTH and sex hormones) and cause gut dysbiosis. These alterations (via direct and/or indirect mechanisms) result in dysregulated bone-mineral metabolism, impaired skeletal muscle mass, function, gait and balance, hemodynamic instability and altered energy homeostasis increasing the risks for OP, 
falls and, consequently, OF, which ultimately lead to disability and mortality. Consequences of HPI and $\mathrm{OP} / \mathrm{OF}$ can be connected and influence each other. In an individual patient, the contribution of HPI to development and progression of OP/OF is determined by a constellation of different but interdependent genetic, hormonal, metabolic, inflammatory and nutritional pathomechanisms, each of which alone and/or in combination may cause specific impairments of multiple organs (remote from the primary infection site) and their functions linked to OFs. The involved processes are highly complex, integrated and may significantly differ in individual patients. Of note, the estimated heritability of BMD is $60-90 \%$, of muscle-related traits is $30-50 \%$, and of OFs is approximately $50 \%(9.5-70 \%)$, indicating the importance to address non-heritable modifiable (including HPI-related) risk factors for OP/OF. (The roles of the site, type and severity of the HPI-induced gastritis and effects of specific treatments in the possible causative relationship between HPI and OP/OF are not depicted here).

\section{Clinical Implications and Recommendations}

Although colonization with H.p. is not a disease in itself, HPI is considered the most important etiological factor for developing main gastroduodenal disorders and a possible contributor to various extra-digestive conditions linked with OP/OF. HPI as a potential determinant of the stomach/gut-OP/OF axis remains largely overlooked and neglected. Although currently most physicians remained skeptical of HPI-OP/OF relationship, the emerging information indicates that the possibility of such link should not be dismissed. The practical rational and need to pay more attention to HPI (among other non-heritable and modifiable RF for OP/OFs) is further supported by the following facts. Firstly, the high level of genetic predisposition to OP, muscle status and OF: the heritability of BMD was estimated between $60 \%$ and $90 \%$ [616-618], the heritability of OFs was estimated between $9.5 \%$ [619] to $16-35 \%$ [620-622] and 53-70\% [617,623,624] and the heritability of muscle-related traits was estimated between $30 \%$ and 50\% [625-627]. Secondly, only in half of patients (between 30\% and 50\%) antiresorptive drugs are effective [628-632]. Thirdly, among lifestyle preventive measures, only muscle strengthening, balance and posture exercises are beneficial (level of evidence A), whereas reduced smoking (level of evidence $C$ ) and alcohol consumption (level of evidence D) demonstrate low relevance [633,634]. It seems reasonable that accounting for more modifiable factors which contribute to $\mathrm{OP} / \mathrm{OF}$ would reveal new possible states and thus lead to better management.

The heterogeneousness of HPI-host interactions indicates that the understanding and interpretation of the HPI-OP/OF link(s) could not focus on a single organ disorder but should account the highly complex integrated processes involving different system organs. These processes may significantly differ in individual patients and the identification of predominant mechanisms as determinants of clinical outcome(s) might be crucial for personalized management. Each patient with HPI has their own interplay of different pathomechanisms which may impact skeleton, falls or both. General and HPI-related RFs for OP/OF are summarized in Table 3. Effective reduction of both bone loss and risk of falls is equally important to prevent OFs. 
Table 3. Risk factors (RF) for osteoporotic fracture in patients with Helicobacter pylori infection.

\begin{tabular}{|c|c|}
\hline General/Common RF & HPI-Induced Diseases and Disorders \\
\hline Advanced age & Anemia, iron deficiency \\
\hline Menopause/male hypogonadism & Vitamin B12 deficiency \\
\hline Body mass loss & Immune thrombocytopenia \\
\hline Low BMD & Chronic/atrophic gastritis \\
\hline Previous fragility fracture & PUD \\
\hline History of falls & Gastric malignancy \\
\hline Family history of $\mathrm{OP} / \mathrm{OFs}$ & HPI- associated chronic diseases and disorders \\
\hline $\begin{array}{l}\text { Ethnicity (Caucasian and Asian vs. black } \\
\text { populations) }\end{array}$ & $\begin{array}{l}\text { Cardiovascular diseases (CAD, } \mathrm{CHF}, \mathrm{AF}, \\
\text { hypertension) }\end{array}$ \\
\hline $\begin{array}{l}\text { Impaired balance, gait and mobility, need of assistive } \\
\text { device * }\end{array}$ & $\begin{array}{l}\text { Hemodynamic instability (orthostatic and/or } \\
\text { postprandial hypotension, dizziness) \# }\end{array}$ \\
\hline Low physical activity/immobilization & Cerebrovascular diseases (stroke, TIA) \\
\hline Low body mass index & $\begin{array}{l}\text { Neurodegenerative diseases (dementia, } \\
\text { Parkinson's disease) }\end{array}$ \\
\hline $\begin{array}{l}\text { Hemodynamic instability (orthostatic and/or } \\
\text { postprandial hypotension, dizziness) \# }\end{array}$ & COPD \\
\hline Visual impairment & CKD \\
\hline Vitamin D deficiency/insufficiency & Diabetes mellitus \\
\hline Vitamin K deficiency & Metabolic syndrome \\
\hline Hyperparathyroidism & CLD \\
\hline Urinary incontinence \# & Depression, anxiety \\
\hline Low calcium intake & Rheumatologic diseases \\
\hline Fear of falling \# & $\begin{array}{l}\text { Eye diseases (open-angle glaucoma, } \\
\text { neuromyelitis optica) }\end{array}$ \\
\hline $\begin{array}{l}\text { Prolonged use of certain medications } \\
\text { Corticosteroids, antidepressants (especially, SSRIs, } \\
\text { SSNRIs), opioids, anxiolytics, hypnotics, sedatives } \\
\text { (benzodiazepines), antiparkinsonian (dopaminergic) }\end{array}$ & Gut dysbiosis \\
\hline $\begin{array}{l}\text { medications, antipsychotics, antiepileptics, glitazones, } \\
\text { antiarrhythmics, PPIs, thyroxine, aromatase } \\
\text { inhibitors, gonadotropin releasing hormone } \\
\text { antagonists, immunosuppressive agents, } \\
\text { polypharmacy }\end{array}$ & $\begin{array}{l}\text { Malignant tumors (breast, lung, colorectal, } \\
\text { prostate cancers) }\end{array}$ \\
\hline Environmental, lifestyle and socio-economic RF & \\
\hline $\begin{array}{l}\text { Cigarette smoking, excess alcohol consumption, diet, } \\
\text { urbanization, poor sanitation conditions, } \\
\text { air pollution. }\end{array}$ & \\
\hline
\end{tabular}

Abbreviations: $\mathrm{AF}$, atrial fibrillation; $\mathrm{CAD}$, coronary artery disease; $\mathrm{CHF}$, congestive heart failure; $\mathrm{CKD}$, chronic kidney disease; CLD, chronic liver disease; COPD, chronic obstructive pulmonary disease; CVD, cardiovascular disease; PPI, proton pump inhibitor; PUD, peptic ulcer disease; SSRI, selective serotonin reuptake inhibitors; SSNRI, selective serotonin-norepinephrine reuptake inhibitors; TIA, transient ischemic attack; \# Risk factor for falls (not for OP); * although need for an assistive device indicates presence of conditions predisposing to falls, its appropriate use may actually decrease fall risk. Notes: Recent genetic studies have challenged some long-assumed risk factors for OP/OF. Mendelian randomization analyses identified BMD [413,635-637], serum estradiol concentrations (in men) [638] and cigarette smoking [639] as causal risk factors for OP/OFs, whereas genetic predisposition to lower levels of vitamin D and milk calcium intake [635,636,639,640], serum testosterone [638] and inflammation markers [641,642], as well as early menopause; late puberty, chronic (including CVD, DM and IBD) $[413,414,643]$ and neuropsychiatric diseases (Alzheimer's disease, schizophrenia and bipolar disorder) [644], alcohol consumption [645] and alcohol dependence [639] did not show causal effects on BMD and fracture risk. The genetic studies overcome many limitations of the previous observational studies but also contain potential bias; "the Mendelian randomization study design cannot be used to assess whether complications or treatment of those diseases influence fracture risk" [636].

We propose a five-step algorithm to address and integrate the potential role of HPI in OP/OF management (Table 4). This practical approach includes, in addition to evaluation of common RFs, assessment for presence or history of HPI-associated diseases and concomitant treatments focusing on use of bone affecting and fall-risk increasing drugs (Step 1), and, when indicated, investigation the patient's HPI status (Step 2), the main bone-mineral characteristics (Step 3) and the specific HPI-related conditions/complications (such as iron deficiency/anemia and gut dysbiosis) linked to 
$\mathrm{OP} / \mathrm{OF}$ (Step 4), and introduction of a personalized and holistic therapeutic strategy addressing the identified disorders and their combinations (Step 5). The proposed algorithm is based on the existing clinical and pathophysiological data and appears well feasible. Such approach, we hope, may help to identify more high-risk patients and yield improved information on individualized prediction, prevention and treatment of OP/OF; it can be useful for early intervention strategies targeting novel potentially preventable and treatable conditions.

Table 4. Algorithm for osteoporotic fracture risk assessment and management in regard to Helicobacter pylori infection.

\begin{tabular}{l} 
Step 1. Assess, in addition to evaluation common risk factors for OP/OF, presence or history of \\
HPI-induced and HPI-associated diseases and disorders and check the appropriateness of concomitant \\
treatments (the potential role of drugs used in regard to OP and falls) (see Table 3). \\
\hline Step 2. If indicated, assess current HPI status, the microbe's virulent characteristics, predominant site, \\
type and severity of gastritis. \\
Step 3. Assess the bone-mineral status (BMD, bone turnover markers, serum levels of vitamin D, \\
vitamin B12, PTH, calcium, phosphate and magnesium). \\
\hline Step 4. Evaluate for and address HPI-related specific conditions/complications associated with OP and/or \\
falls (e.g., iron deficiency/anemia, gut dysbiosis, hemodynamic instability, gait disturbance, frailty, etc.). \\
\hline Step 5. Introduce a personalized and holistic care plan of preventive and/or therapeutic management \\
according the identified disorders and their combinations. This may include: (1) HPI eradication; \\
(2) adequate antiosteoporotic treatment; (3) elimination/minimization falls-related factors (alleviation \\
effects of chronic diseases and/or drugs causing hemodynamic instability, gait disturbances, muscle loss, \\
frailty); (4) review and optimization of all medications used; (5) correction the metabolic alterations \\
(vitamin D, iron and vitamin B12), hormonal status, anemia and gut dysbiosis (e.g., pre- and probiotic \\
therapy); (6) nutritional support; and (7) modulation of lifestyle factors (physical activity, tobacco smoking \\
and alcohol consumption).
\end{tabular}

Noticeable, common RF favoring development of OP/OF are frequently present in patients with HPI (Table 3). Our ability to fully understand countless HPI effects and risks for any one patient is still limited. To illustrate some clinically relevant examples of up- or downregulated pathways that may eventually trigger $\mathrm{OP} / \mathrm{OF}$, we briefly describe the effects related to site-specific differences in HPI-induced gastritis (two of multiple possible scenarios) and the role of two HPI-induced disorders-iron deficiency/anemia and gut dysbiosis.

Scenario 1. In a patient with HPI-induced (especially with cagA+ strains) chronic/atrophic corpus gastritis, several factors may affect OP/OF. Hypo-/achlorhydria; iron and/or vitamin B12 insufficiency/deficiency; hypoghrelinemia; decreased production of gastric/gut estrogens and dopamine; increased gastrin, histamine and PTH production; alterations in serotonin levels; and gut dysbiosis may impair nutrients absorption, cause alterations in mineral metabolism (calcium, phosphate and magnesium) and stimulate bone degradation. These factors and the systemic low-grade inflammation may contribute to dysregulations in many other system organs and affect energy homeostasis resulting in muscle weakness, hemodynamic instability, weight loss and gait abnormalities—disorders associated with OP and elevated risk for falling.

Scenario 2. In individuals with HPI-induced predominantly antral gastritis, decreased somatostatin and increased gastrin levels, gastric acid hypersecretion and PUD (in a significant proportion of affected subjects) would be expected. In these patients, iron deficiency/anemia may be caused by gastroduodenal bleeding (a common PUD complication), while use of PPIs may affect absorption of calcium and some nutrients and in combination with HPI contribute to gut dysbiosis, a condition strongly associated with $\mathrm{OP} / \mathrm{OFs}$.

Crucially, in any case, an increased expression of systemic low-grade inflammation (due to microbe's specific virulence factors), hosts' genetic predisposition and/or microbe's antigenic mimicry, alongside the abovementioned HPI-induced metabolic and hormonal alterations, might convey strong 
direct and indirect effects on bone homeostasis, muscles, cardiovascular, nervous and other systems linked with OFs.

Among the wide array of different diseases associated with both HPI and susceptibility to OP/OF, we would like to emphasize particularly the role of HPI-induced alterations in iron homeostasis and gut microbiota. Both these disorders are significantly implicated in a wide variety of disease states linked to $\mathrm{OP} / \mathrm{OFs}$ but often overlooked and ignored in clinical practice.

Iron deficiency/anemia is a worldwide highly prevalent disorder (1.2 billion people [646]; 15-30\% among older adults $[647,648]$ ) associated with detrimental effects in multiple medical conditions [649] including OP/OF. HPI is considered an important cause of iron deficiency and anemia; these conditions are among few disorders included in HPI international consensus management guidelines [360]. However, in persons with HPI-induced iron deficiency/anemia, diagnostic tests for OP and preventive osteoporotic treatment are still not advocated. The awareness that impaired iron status may be induced by HPI and may lead to OP/OF is critical. Individuals with OP/OF should be screened and monitored for iron deficiency/anemia, its underlying etiology identified (is it HPI-related?) and the iron status corrected. On the other hand, all clinicians, regardless of their specialty, should be encouraged to assess bone status in patients with iron deficiency/anemia and to introduce, when appropriate, osteoporotic therapy. Currently, however, clinical management (diagnosis and treatment) of iron deficiency is suboptimal or even inadequate [650], particularly in regard to OP/OF [358,651,652]. Building inter-disciplinary bridges to address this problem is important.

The other topic which deserves more attention is HPI-associated dysregulation of gut microbiota [239,606,653-667], a phenomenon described also in animal models (infected Mongolian gerbils [668]) and thought to be due mainly to gut immunopathological/inflammatory responses and suppressed gastric acid secretion following chronic/atrophic gastritis or use of acid-suppressive drugs. Gut dysbiosis by affecting various biological processes contributes to the pathogenesis of OP [669-699] as well as to numerous other extra-digestive system diseases associated with OFs [700-709].

Within this context, it should be mentioned that gastrointestinal microbiota profiles may also be altered by medications commonly used in HPI-related diseases (antibiotics, PPIs, SSRIs, opioids, NSAIDs, antipsychotics, anticholinergic inhalers, polypharmacy) [701,710-721]. The most recent publication found that 19 of 41 analyzed drugs influence gut microbiome composition [720]; PPIs, antibiotics, metformin, SSRIs, NSAIDs, antipsychotics and laxatives showed the strongest associations $[715,717,720]$. The PPI-induced dysbiosis has been reported in recent studies and reviews $[715,718,722-727]$ and again confirmed in the latest systemic review based on 11 interventional and 12 observational cohort studies [728].

The eradication of HPI can restore the microbial diversity and increase the abundance of beneficial bacteria (e.g., Lactobacillus and Bifidobacterium) [729]. Restoring a balanced gut microbiota is considered as a therapeutic tool for various diseases, including OP [695,730-737]. Recent studies showed that probiotic and prebiotic supplementation increases bone density in healthy individuals, protects against primary and secondary OP [687,695,699,734,738-740] and exerts beneficial effects in many other extra-digestive diseases [740]. However, despite the established impact of the gut microbiota on host (patho-) physiology, the potential roles of HPI- and medications-induced gut dysbiosis is not mentioned in current guidelines for OP.

To put together, the challenge is to find the right practical approach to evaluate simultaneously presence of HPI and its characteristics, the bone status and risk of falls and timely introduce appropriate individualized therapies avoiding both under- and over-diagnosis. In patients with HPI-induced diseases bone characteristics, risk for falls and fractures should be assessed, whereas in individuals with risk or presence of OP/OF the investigation for HPI needs to be considered and if the infection identified appropriate treatment prescribed.

Since HPI is associated with many extra-digestive pathologies which might not be clinically obvious (silent alterations in mineral-bone metabolism, iron and/or vitamin B12 deficiencies, hormonal imbalance, gut dysbiosis, etc.) and patients are often followed by clinicians other than 
gastroenterologists (primary care doctors, cardiologists, hematologists, endocrinologists, oncologists, orthopedic surgeons, etc.), multi-disciplinary cooperation/collaboration is important and cross referrals should be considered. A multidisciplinary approach seems to be fruitful when dedicated professionals appreciate each other's contributions and priorities.

Recognizing multiple HPI-induced diseases as contributing to both bone health and falls and deeper understanding the complex biology of the HPI-OF axis may lead to reconceptualizing the $\mathrm{OP} / \mathrm{OF}$ management; the proposed algorithm, we expect, can be used as the first draft. In addition to existing strategies, the new interventions might include assessment the HPI status, HPI eradication, use of ghrelin (and its analogues), especially in HPI-induced chronic/atrophic corpus gastritis, treating (when appropriate) iron and vitamin B12 deficiencies, correcting gut dysbiosis-to mention some therapies which showed encouraging results and needed to be confirmed in longitudinal studies.

However, in recent international guidelines for prediction and prevention OP/OFs, the potential role of HPI is not mentioned [358]. Detection and eradication of H.p. are not part of OP/OF management, despite very high prevalence of HPI throughout the world (more in the elderly), growing research data on HPI-OP/OF link and the alarming expectations that in the coming decades the incidence of OFs will significantly increase worldwide as the population is ageing [741-745]. In short, taking a wider approach on $\mathrm{OP} / \mathrm{OF}$, considering the potential pathophysiological role(s) of HPI-induced diseases and disorders and generating a new paradigm may improve managing strategies, provide new angles for optimization OP care, prevent future fractures and lead to novel therapeutic options.

\section{Limitations}

It is worth emphasizing, as stated in the previous sections, that interpretation of controversial data on HPI-OP/OF relationships should take into account the methodological weaknesses most of the available studies (the vast majority were cross-sectional). The conflicting results are likely due not only to differences in design, sample sizes, protocol and methodologies of determination HPI (often limited to seroprevalence only) as well as OP (T-score BMD method underestimates the OF risk in 56-82\% [746-750]), but also-and more importantly-very limited information on specific microbiological characteristics of H.p., ignoring predominant site and severity of gastritis, heterogeneity in patient populations (wide variations in demographic, socioeconomic, lifestyle, dietary and environmental confounding factors, comorbidities, risk of falling, used medications), However, despite these limitations, the huge number of publications reporting significant links between HPI, particularly with virulent strains (cagA+), and the development, course and severity of different chronic gastroduodenal and extra-digestive diseases and disorders known to be associated with falls, $\mathrm{OP}$ and, consequently, OFs cannot be ignored. The topic requires reconsideration in well-designed prospective studies examining simultaneously the virulence factors of H.p., host's susceptibility, its neuroendocrine-immunological-inflammatory response to HPI, socio-demographic, environmental and clinical characteristics including objective measurements of bone status (mineral-bone metabolism, $\mathrm{BMD})$, risk factors for falls and occurrence of $\mathrm{OF}$.

\section{Conclusions}

In this review, we attempt to illuminate the existing clinical information on links between $\mathrm{HPI}$ and $\mathrm{OP} / \mathrm{OFs}$ and, the complexity and interdependence of HPI-host interactions. The available evidence indicates that diseases and disorders induced by HPI (especially with virulent strains (cagA+) may contribute directly and indirectly to the development and progression of $\mathrm{OP}$, falls and OFs. Despite remaining gaps in knowledge (the underlying mechanisms have not been definitely proven), there is considerable amount of data to suggest that predictive, preventive and therapeutic strategies for OP/OFs should assume HPI-related pathologies as potential pathophysiological co-factors and concentrate on individualized management of their effects on both bone health and falls. In patients with HPI-associated diseases and disorders bone status and risk for falls and fractures should be assessed, whereas in individuals with risk or presence of OP/OF the HPI status needs to be investigated 
and appropriate treatment prescribed. A five-step algorithm to provide guidance on assessment of the possible contribution of HPI to OP/OF is presented; its clinical effectiveness needs to be validated. Further well-designed prospective studies are warranted to provide a deeper understanding of the $\mathrm{HPI-OP} / \mathrm{OFs}$ axis and develop personalized preventive and curative therapies.

\section{Key Points}

- H.p. colonizes about half of the world population. HPI as a multi-system condition confined not only to gastroduodenal morbidity but also many chronic extra-digestive diseases (CVD, neurodegenerative, endocrine, CLD, CKD, etc.) might directly and/or indirectly affect bone status, predispose to falls and, consequently, to OFs.

- The relationship between HPI and OP/OFs, two common, multifactorial and heterogeneous conditions, depends on complex interactions of multiple factors, including microbe's virulence, host genetic predisposition, local gastroduodenal and systemic responses (biochemical, metabolic, hormonal, immunologic and inflammatory) and environmental influences. Therefore, microbe's contribution to development and progression of $\mathrm{OP} / \mathrm{OF}$ and the risk profile in colonized individuals could vary significantly. When studying the role of HPI in OP/OF, correction for the mentioned factors, is essential.

- The data on associations between HPI and OP/OFs in the literature are inconsistent, but there is growing evidence that HPI (especially in persons infected with virulent strains, e.g., $\operatorname{cag} A+$ ) increases risk of OP/OF approximately 1.5-2-fold.

- Given the widespread prevalence of HPI in the population, the practical implication for these data is that comprehensive assessment for OP/OF risks should include evaluation for HPI-related diseases and disorders and vice versa (assessment for HPI in subjects with established OP, falls and low energy fractures); such approach would assist in individualized prevention and treatment of $\mathrm{OP} / \mathrm{OFs}$ and should be considered at health care policy level.

- The usefulness and applicability of a practical strategy addressing HPI, an easy identifiable and treatable condition, as a potential pathophysiological co-factor of $\mathrm{OP} / \mathrm{OF}$, are worth further investigation in controlled, long-term studies with simultaneous assessment of H.p., host's and environmental characteristics; a better understanding of the mechanisms underlying HPI-OP/OF relationship and individual outcomes should be achieved.

Addendum: After this review had been finalised and submitted to the Journal Gennari L et al. [J Bone Miner Res. 2020 Aug 13. doi: 10.1002/jbmr.4162. Online ahead of print] published a prospective cohort study which demonstrated that HPI with CagA-positive strains significantly increases the risk for OP/OF.

Author Contributions: Conceptualization, L.F.; literature search, review and original draft preparation, L.F. and A.F.; graphical design and tables, L.F.; and editing, L.F., A.F. and P.N.S. All authors have read and agreed to the published version of the manuscript.

Funding: This research received no external funding.

Conflicts of Interest: The authors declare no conflict of interest.

$\begin{array}{ll}\text { Abbreviations } \\ \text { BMD } & \text { bone mineral density } \\ \text { bALP } & \text { bone-specific alkaline phosphatase } \\ \beta-C T X & \beta \text {-collagen I carboxy terminal telopeptide } \\ \text { BO } & \text { Barrett's esophagus } \\ \text { Ca } & \text { calcium } \\ \text { CAD } & \text { coronary artery disease } \\ \text { cagA } & \text { cytotoxin-associated gene A } \\ \text { CagA } & \text { cytotoxin associated antigen A } \\ \text { CHF } & \text { congestive heart failure } \\ \text { CKD } & \text { chronic kidney disease }\end{array}$




$\begin{array}{ll}\text { COPD } & \text { chronic obstructive pulmonary disease } \\ \text { CVD } & \text { cardiovascular disease } \\ \text { DC } & \text { dendritic cell } \\ \text { DM } & \text { diabetes mellitus } \\ \text { GERD } & \text { gastroesophageal reflux disease } \\ \text { HRT } & \text { hormone replacement therapy } \\ \text { H.p. } & \text { Helicobacter pylori } \\ \text { HPI } & \text { Helicobacter pylori infection } \\ \text { H2RA } & \text { histamine-2 receptor antagonist } \\ \text { HR } & \text { hazard ratio } \\ \text { IL } & \text { interleukin } \\ \text { ITT } & \text { idiopathic thrombocytopenic purpura } \\ \text { Mg } & \text { magnesium } \\ \text { MALT } & \text { mucosa-associated lymphoid tissue B-cell lymphoma } \\ \text { MAFLD } & \text { metabolic associated fatty liver disease } \\ \text { OC } & \text { osteocalcin } \\ \text { OF } & \text { osteoporotic fracture } \\ \text { OP } & \text { osteoporosis } \\ \text { OPG } & \text { osteoprotegerin } \\ \text { RF } & \text { risk factor } \\ \text { P1NP } & \text { N-terminal cross-links of human procollagen type I } \\ \text { PO } & \text { phosphate } \\ \text { PPI } & \text { proton pump inhibitor } \\ \text { PTH } & \text { parathyroid hormone } \\ \text { PUD } & \text { peptic ulcer disease } \\ \text { RA } & \text { rheumatoid arthritis } \\ \text { RANK } & \text { receptor activator of nuclear factor kB } \\ \text { RANKL } & \text { receptor activator of nuclear factor-kappa B (NF-kB) ligand } \\ \text { TNF- } \alpha & \text { tumor necrosis factor alpha } \\ & \end{array}$

\section{References}

1. Karsenty, G.; Ferron, M. The contribution of bone to whole-organism physiology. Nat. Cell Biol. 2012, 481, 314-320. [CrossRef]

2. Kitay, A.M.; Geibel, J.P. Stomach and Bone. Adv. Exp. Med. Biol. 2017, 1033, 97-131.

3. Suchacki, K.J.; Roberts, F.; Lovdel, A.; Farquharson, C.; Morton, N.M.; Macrae, V.E.; Cawthorn, W.P.; Morton, N.M.; Cawthorn, W. Skeletal energy homeostasis: A paradigm of endocrine discovery. J. Endocrinol. 2017, 234, R67-R79. [CrossRef]

4. Ramsey, W.; Isales, C.M. Intestinal Incretins and the Regulation of Bone Physiology. Adv. Exp. Med. Biol. 2017, 1033, 13-33.

5. Schiellerup, S.P.; Skov-Jeppesen, K.; Windeløv, J.A.; Svane, M.S.; Holst, J.J.; Hartmann, B.; Rosenkilde, M. Gut Hormones and Their Effect on Bone Metabolism. Potential Drug Therapies in Future Osteoporosis Treatment. Front. Endocrinol. 2019, 10, 75. [CrossRef]

6. Guntur, A.R.; Rosen, C.J. Bone as an Endocrine Organ. Endocr. Pract. 2012, 18, 758-762. [CrossRef]

7. Wong, I.P.; Baldock, P.A.; Herzog, H. Gastrointestinal peptides and bone health. Curr. Opin. Endocrinol. Diabetes Obes. 2010, 17, 44-50. [CrossRef]

8. Blaser, M.J.; Atherton, J.C. Helicobacter pylori persistence: Biology and disease. J. Clin. Investig. 2004, 113, 321-333. [CrossRef]

9. Atherton, J.C.; Blaser, M.J. Coadaptation of Helicobacter pylori and humans: Ancient history, modern implications. J. Clin. Investig. 2009, 119, 2475-2487. [CrossRef]

10. Hooi, J.K.; Lai, W.Y.; Ng, W.K.; Suen, M.M.; Underwood, F.E.; Tanyingoh, D.; Malfertheiner, P.; Graham, D.Y.; Wong, V.W.; Wu, J.C.; et al. Global Prevalence of Helicobacter pylori Infection: Systematic Review and Meta-Analysis. Gastroenterology 2017, 153, 420-429. [CrossRef] 
11. Franceschi, F.; Tortora, A.; Gasbarrini, G.; Gasbarrini, A. Helicobacter pyloriand Extragastric Diseases. Helicobacter 2014, 19, 52-58. [CrossRef]

12. Upala, S.; Sanguankeo, A.; Wijarnpreecha, K.; Jaruvongvanich, V. Association between Helicobacter pylori infection and osteoporosis: A systematic review and meta-analysis. J. Bone Miner. Metab. 2015, 34, 482-483. [CrossRef]

13. Papamichael, K.; Papaioannou, G.; Cheifetz, M.A.; Cheifetz, A.S. Bone of Contention: Helicobacter pylori and Osteoporosis-Is There an Association? Dig. Dis. Sci. 2019, 64, 2736-2739. [CrossRef]

14. Wang, T.; Li, X.; Zhang, Q.; Ge, B.; Zhang, J.; Yu, L.; Cai, T.; Zhang, Y.; Xiong, H. Relationship betweenHelicobacter pyloriinfection and osteoporosis: A systematic review and meta-analysis. BMJ Open 2019, 9, e027356. [CrossRef]

15. Kodaman, N.; Pazos, A.; Schneider, B.G.; Piazuelo, M.B.; Mera, R.; Sobota, R.S.; Sicinschi, L.A.; Shaffer, C.L.; Romero-Gallo, J.; De Sablet, T.; et al. Human and Helicobacter pylori coevolution shapes the risk of gastric disease. Proc. Natl. Acad. Sci. USA 2014, 111, 1455-1460. [CrossRef]

16. Warren, J.R. Unidentified Curved Bacilli on Gastric Epithelium in Active Chronic Gastritis. Lancet 1983, 321, 1273-1275.

17. Marshall, B.; Warren, J. Unidentified Curved Bacilli in The Stomach of Patients with Gastritis And Peptic Ulceration. Lancet 1984, 323, 1311-1315. [CrossRef]

18. Medina, M.L.; Medina, M.G.; Merino, L.A. Correlation between virulence markers of Helicobacter pylori in the oral cavity and gastric biopsies. Arq. Gastroenterol. 2017, 54, 217-221. [CrossRef]

19. Lu, L.-J.; Hao, N.-B.; Liu, J.-J.; Li, X.; Wang, R.-L. Correlation between Helicobacter pylori Infection and Metabolic Abnormality in General Population: A Cross-Sectional Study. Gastroenterol. Res. Pract. 2018, 2018, 1-6. [CrossRef]

20. Roesler, B.M.; Rabelo-Gonçalves, E.M.; Zeitune, J.M. Virulence Factors of Helicobacter pylori: A Review. Clin. Med. Insights: Gastroenterol. 2014, 7, 9-17.

21. Waldum, H.L.; Kleveland, P.M.; Sørdal, Ø.F. Helicobacter pyloriand gastric acid: An intimate and reciprocal relationship. Ther. Adv. Gastroenterol. 2016, 9, 836-844. [CrossRef]

22. Ansari, S.; Yamaoka, Y. Survival of Helicobacter pylori in gastric acidic territory. Helicobacter 2017, 22 , e12386. [CrossRef]

23. Smolka, A.J.; Schubert, M.L. Helicobacter pylori-Induced Changes in Gastric Acid Secretion and Upper Gastrointestinal Disease. Future HIV 1 Ther. 2017, 400, 227-252.

24. Marcus, E.A.; Tokhtaeva, E.; Jimenez, J.L.; Wen, Y.; Naini, B.V.; Heard, A.N.; Kim, S.; Capri, J.; Cohn, W.; Whitelegge, J.P.; et al. Helicobacter pylori infection impairs chaperone-assisted maturation of Na-K-ATPase in gastric epithelium. Am. J. Physiol. Liver Physiol. 2020, 318, G931-G945. [CrossRef]

25. Navabi, N.; Johansson, M.E.V.; Raghavan, S.; Linden, S.K. Helicobacter pylori Infection Impairs the Mucin Production Rate and Turnover in the Murine Gastric Mucosa. Infect. Immun. 2012, 81, 829-837. [CrossRef]

26. Fosslien, E. Mitochondrial medicine-molecular pathology of defective oxidative phosphorylation. Ann. Clin. Lab. Sci. 2001, 31, 25-67.

27. Sachs, G.; Weeks, D.L.; Melchers, K.; Scott, D.R. The Gastric Biology of Helicobacter pylori. Annu. Rev. Physiol. 2003, 65, 349-369. [CrossRef]

28. Kemmerly, T.; Kaunitz, J.D. Gastroduodenal mucosal defense. Curr. Opin. Gastroenterol. 2013, $29,642-649$. [CrossRef]

29. De Brito, B.B.; Da Silva, F.A.F.; Soares, A.S.; Pereira, V.A.; Santos, M.L.C.; Sampaio, M.M.; Neves, P.H.M.; Melo, F. Pathogenesis and clinical management of Helicobacter pylori gastric infection. World J. Gastroenterol. 2019, 25, 5578-5589. [CrossRef]

30. Zhang, X.; Arnold, I.C.; Müller, A. Mechanisms of persistence, innate immune activation and immunomodulation by the gastric pathogen Helicobacter pylori. Curr. Opin. Microbiol. 2020, 54, 1-10. [CrossRef]

31. Šterbenc, A.; Jarc, E.; Poljak, M.; Homan, M. Helicobacter pylori virulence genes. World J. Gastroenterol. 2019, 25, 4870-4884. [CrossRef]

32. Marcus, E.A.; Sachs, G.; Scott, D.R. Acid-regulated gene expression of Helicobacter pylori: Insight into acid protection and gastric colonization. Helicobacter 2018, 23, e12490. [CrossRef] 
33. Mayerle, J.; Hoed, C.M.D.; Schurmann, C.; Stolk, L.; Homuth, G.; Peters, M.J.; Capelle, L.G.; Zimmermann, K.; Rivadeneira, F.; Gruska, S.; et al. Identification of Genetic Loci Associated with Helicobacter pylori Serologic Status. JAMA 2013, 309, 1912-1920. [CrossRef]

34. Hunt, R.H.; Camilleri, M.; Crowe, S.; El-Omar, E.M.; Fox, J.; Kuipers, E.; Malfertheiner, P.; McColl, K.; Pritchard, D.; Rugge, M.; et al. The stomach in health and disease. Gut 2015, 64, 1650-1668. [CrossRef]

35. Bartels, L.E.; Dahlerup, J.F. Association of Helicobacter pylori and Crohn's Disease Incidence: An Inversion Reaction? Dig. Dis. Sci. 2017, 62, 2217-2219. [CrossRef]

36. Ishida, Y. Significant association between Helicobacter pylori infection and serum C-reactive protein. Int. J. Med. Sci. 2008, 224. [CrossRef]

37. Jackson, L.; Britton, J.; Lewis, S.A.; McKeever, T.M.; Atherton, J.; Fullerton, D.; Fogarty, A.W. A Population-Based Epidemiologic Study of Helicobacter Pylori Infection and its Association with Systemic Inflammation. Helicobacter 2009, 14, 460-465. [CrossRef]

38. Jafarzadeh, A.; Mirzaee, V.; Ahmad-Beygi, H.; Nemati, M.; Rezayati, M.T. Association of the CagA status of Helicobacter pyloriand serum levels of interleukin (IL)-17 and IL-23 in duodenal ulcer patients. J. Dig. Dis. 2009, 10, 107-112. [CrossRef]

39. Akada, J.; Okuda, M.; Hiramoto, N.; Kitagawa, T.; Zhang, X.; Kamei, S.; Ito, A.; Nakamura, M.; Uchida, T.; Hiwatani, T.; et al. Proteomic Characterization of Helicobacter pylori CagA Antigen Recognized by Child Serum Antibodies and Its Epitope Mapping by Peptide Array. PLoS ONE 2014, 9, e104611. [CrossRef]

40. Shimoda, A.; Ueda, K.; Nishiumi, S.; Murata-Kamiya, N.; Mukai, S.-A.; Sawada, S.-I.; Azuma, T.; Hatakeyama, M.; Akiyoshi, K. Exosomes as nanocarriers for systemic delivery of the Helicobacter pylori virulence factor CagA. Sci. Rep. 2016, 6, 18346. [CrossRef] [PubMed]

41. Hatakeyama, M. Structure and function of Helicobacter pylori CagA, the first-identified bacterial protein involved in human cancer. Proc. Jpn. Acad. Ser. B 2017, 93, 196-219. [CrossRef] [PubMed]

42. Chmiela, M.; Gonciarz, W. Molecular mimicry inHelicobacter pyloriinfections. World J. Gastroenterol. 2017, 23, 3964-3977. [CrossRef]

43. Franceschi, F.; Sepulveda, A.R.; Gasbarrini, A.; Pola, P.; Silveri, N.G.; Gasbarrini, G.; Graham, D.Y.; Genta, R.M. Cross-Reactivity of Anti-CagA Antibodies with Vascular Wall Antigens. Circulation 2002, 106, 430-434. [CrossRef] [PubMed]

44. Rožanković, P.B.; Huzjan, A.L.; Cupic, H.; Benčić, I.J.; Bašić, S.; Demarin, V. Influence of CagA-positive Helicobacter pylori strains on atherosclerotic carotid disease. J. Neurol. 2010, 258, 753-761. [CrossRef]

45. Tohidpour, A. CagA-mediated pathogenesis of Helicobacter pylori. Microb. Pathog. 2016, 93, 44-55. [CrossRef] [PubMed]

46. Ansari, S.; Yamaoka, Y. Helicobacter pylori Virulence Factors Exploiting Gastric Colonization and its Pathogenicity. Toxins 2019, 11, 677. [CrossRef]

47. Knorr, J.; Ricci, V.; Hatakeyama, M.; Backert, S. Classification of Helicobacter pylori Virulence Factors: Is CagA a Toxin or Not? Trends Microbiol. 2019, 27, 731-738. [CrossRef]

48. Higashi, H.; Tsutsumi, R.; Fujita, A.; Yamazaki, S.; Asaka, M.; Azuma, T.; Hatakeyama, M. Biological activity of the Helicobacter pylori virulence factor CagA is determined by variation in the tyrosine phosphorylation sites. Proc. Natl. Acad. Sci. USA 2002, 99, 14428-14433. [CrossRef]

49. Higashi, H.; Tsutsumi, R.; Muto, S.; Sugiyama, T.; Azuma, T.; Asaka, M.; Hatakeyama, M. SHP-2 Tyrosine Phosphatase as an Intracellular Target of Helicobacter pylori CagA Protein. Science 2001, 295, 683-686. [CrossRef]

50. Higashi, H.; Yokoyama, K.; Fujii, Y.; Ren, S.; Yuasa, H.; IMurata-Kamiya, S.N.; Azuma, T.; Hatakeyama, M. EPIYA motif is a membrane-targeting signal of Helicobacter pylori virulence factor CagA in mammalian cells. J. Biol. Chem. 2005, 280, 23130-23137. [CrossRef]

51. Backert, S.; Haas, R.; Gerhard, M.; Naumann, M. The Helicobacter pylori Type IV Secretion System Encoded by the cag Pathogenicity Island: Architecture, Function, and Signaling. Future HIV 1 Ther. 2017, 413, 187-220.

52. Graham, D.Y.; Opekun, A.R.; Belson, G.; El-Zimaity, H.M.T.; Carlson, M.R. Novel bismuth-metronidazole-tetracycline triple-layer tablet for treatment of Helicobacter pylori. Aliment. Pharm. 2005, 21, 165-168. [CrossRef]

53. Brandt, S.; Kwok, T.; Hartig, R.; Konig, W.; Backert, S. NF-kappaB activation and potentiation of proinflammatory responses by the Helicobacter pylori CagA protein. Proc. Natl. Acad. Sci. USA 2005, 102, 9300-9305. [CrossRef] [PubMed] 
54. Hatakeyama, M. Linking epithelial polarity and carcinogenesis by multitasking Helicobacter pylori virulence factor CagA. Oncogene 2008, 27, 7047-7054. [CrossRef]

55. Yamaoka, Y.; Kodama, T.; Gutierrez, O.; Kim, J.G.; Kashima, K.; Graham, D.Y. Relationship between Helicobacter pylori iceA, cagA, and vacA Status and Clinical Outcome: Studies in Four Different Countries. J. Clin. Microbiol. 1999, 37, 2274-2279. [CrossRef]

56. Yamaoka, Y.; Orito, E.; Mizokami, M.; Gutierrez, O.; Saitou, N.; Kodama, T.; Osato, M.S.; Kim, J.G.; Ramirez, F.C.; Mahachai, V.; et al. Helicobacter pyloriin North and South America before Columbus. FEBS Lett. 2002, 517, 180-184. [CrossRef]

57. Yamaoka, Y.; Kato, M.; Asaka, M. Geographic Differences in Gastric Cancer Incidence Can be Explained by Differences between Helicobacter pylori Strains. Intern. Med. 2008, 47, 1077-1083. [CrossRef]

58. Yamaoka, Y. Pathogenesis of Helicobacter pylori-Related Gastroduodenal Diseases from Molecular Epidemiological Studies. Gastroenterol. Res. Pract. 2012, 2012, 1-9. [CrossRef]

59. Suzuki, H.; Mori, H. Different Pathophysiology of Gastritis between East and West? An Asian Perspective. Inflamm. Intest. Dis. 2016, 1, 123-128. [CrossRef]

60. Wirth, H.-P.; Yang, M. Different Pathophysiology of Gastritis in East and West? A Western Perspective. Inflamm. Intest. Dis. 2016, 1, 113-122. [CrossRef]

61. Nakajima, N.; Kuwayama, H.; Ito, Y.; Iwasaki, A.; Arakawa, Y. Helicobacter pylori, Neutrophils, Interleukins, and Gastric Epithelial Proliferation. J. Clin. Gastroenterol. 1997, 25, S198-S202. [CrossRef] [PubMed]

62. Yamaoka, Y.; Reddy, R.; Graham, D.Y. Helicobacter pylori Virulence Factor Genotypes in Children in the United States: Clues about Genotype and Outcome Relationships. J. Clin. Microbiol. 2010, 48, 2550-2551. [CrossRef]

63. Selgrad, M.; Tammer, I.; Langner, C.; Bornschein, J.; Meißle, J.; Kandulski, A.; Varbanova, M.; Wex, T.; Schlüter, D.; Malfertheiner, P. Different antibiotic susceptibility between antrum and corpus of the stomach, a possible reason for treatment failure of Helicobacter pyloriinfection. World J. Gastroenterol. 2014, 20, 16245-16251. [CrossRef]

64. den Hollander, W.J.; Sostres, C.; Kuipers, E.J.; Lanas, A. Helicobacter pyloriand Nonmalignant Diseases. Helicobacter 2013, 18, 24-27. [CrossRef]

65. Link, A.; Langner, C.; Schirrmeister, W.; Habendorf, W.; Weigt, J.; Venerito, M.; Tammer, I.; Schlüter, D.; Schlaermann, P.; Meyer, T.F.; et al. Helicobacter pylorivacA genotype is a predominant determinant of immune response toHelicobacter pyloriCagA. World J. Gastroenterol. 2017, 23, 4712-4723. [CrossRef]

66. Stein, M.; Ruggiero, P.; Rappuoli, R.; Bagnoli, F. Helicobacter pylori CagA: From Pathogenic Mechanisms to Its Use as an Anti-Cancer Vaccine. Front. Immunol. 2013, 4, 328. [CrossRef]

67. Chang, W.-L.; Yeh, Y.-C.; Sheu, B.-S. The impacts of H. pylori virulence factors on the development of gastroduodenal diseases. J. Biomed. Sci. 2018, 25, 68. [CrossRef]

68. Meng, W.-P.; Wang, Z.-Q.; Deng, J.-Q.; Liu, Y.; Deng, M.-M.; Lü, M.-H. The Role of H. pyloriCagA in Regulating Hormones of Functional Dyspepsia Patients. Gastroenterol. Res. Pract. 2016, 2016, 7150959. [CrossRef]

69. Van Doorn, L.J.; Figueiredo, C.; Sanna, R.; Blaser, M.J.; Quint, W.G. Distinct variants of Helicobacter pylori cagA are associated with vacA subtypes. J. Clin. Microbiol. 1999, 37, 2306-2311. [CrossRef]

70. Miftahussurur, M.; Yamaoka, Y. Helicobacter pylorivirulence genes and host genetic polymorphisms as risk factors for peptic ulcer disease. Expert Rev. Gastroenterol. Hepatol. 2015, 9, 1535-1547. [CrossRef]

71. Wang, J.; Zhang, Q.; Liu, Y.; Han, J.; Ma, X.; Luo, Y.; Liang, Y.; Zhang, L.; Hu, Y. Association between HLA-IIgene polymorphism and Helicobacter pylori infection in Asian and European population: A meta-analysis. Microb. Pathog. 2015, 82, 15-26. [CrossRef] [PubMed]

72. Ma, J.; Wu, D.; Hu, X.; Li, J.; Cao, M.; Dong, W. Associations between cytokine gene polymorphisms and susceptibility to Helicobacter pylori infection and Helicobacter pylori related gastric cancer, peptic ulcer disease: A meta-analysis. PLoS ONE 2017, 12, e0176463. [CrossRef] [PubMed]

73. Dooley, C.P.; Cohen, H.; Fitzgibbons, P.L.; Bauer, M.; Appleman, M.D.; Perez, G.I.P.; Blaser, M.J. Prevalence of Helicobacter pyloriInfection and Histologic Gastritis in Asymptomatic Persons. N. Engl. J. Med. 1989, 321, 1562-1566. [CrossRef] [PubMed]

74. Kang, J.; Blaser, M.J. Bacterial populations as perfect gases: Genomic integrity and diversification tensions in Helicobacter pylori. Nat. Rev. Genet. 2006, 4, 826-836. [CrossRef] 
75. Cover, T.L.; Blaser, M.J. Helicobacter pylori in Health and Disease. Gastroenterology 2009, 136, $1863-1873$. [CrossRef] [PubMed]

76. Sachs, G.; Scott, D.R. Helicobacter pylori: Eradication or Preservation. F1000 Med. Rep. 2012, 4, 7. [PubMed]

77. Kayali, S.; Manfredi, M.; Gaiani, F.; Bianchi, L.; Bizzarri, B.; Leandro, G.; di Mario, F.; de Ángelis Gian, L. Helicobacter pylori, transmission routes and recurrence of infection: State of the art. Acta Biomed. 2018, 89, 72-76.

78. Arnold, I.C.; Hitzler, I.; Müller, A. The Immunomodulatory Properties of Helicobacter pylori Confer Protection Against Allergic and Chronic Inflammatory Disorders. Front. Cell. Infect. Microbiol. 2012, 2, 10. [CrossRef]

79. Kyburz, A.; Müller, A. Helicobacter pylori and Extragastric Diseases. Future HIV 1 Ther. 2017, 400, 325-347.

80. Malfertheiner, P. The Intriguing Relationship of Helicobacter pylori Infection and Acid Secretion in Peptic Ulcer Disease and Gastric Cancer. Dig. Dis. 2011, 29, 459-464. [CrossRef]

81. Walker, M.M.; Talley, N.J. Review article: Bacteria and pathogenesis of disease in the upper gastrointestinal tract-beyond the era of Helicobacter pylori. Aliment. Pharm. 2014, 39, 767-779. [CrossRef]

82. Paoluzi, O.A.; Blanco, D.V.G.; Caruso, R.; Monteleone, I.; Monteleone, G.; Pallone, F. Impairment of ghrelin synthesis inHelicobacter pylori-colonized stomach: New clues for the pathogenesis of H. pylori-related gastric inflammation. World J. Gastroenterol. 2014, 20, 639-646. [CrossRef]

83. Schubert, M.L. Physiologic, pathophysiologic, and pharmacologic regulation of gastric acid secretion. Curr. Opin. Gastroenterol. 2017, 33, 430-438. [CrossRef]

84. Burclaff, J.; Osaki, L.H.; Liu, D.; Goldenring, J.R.; Mills, J.C. Targeted Apoptosis of Parietal Cells Is Insufficient to Induce Metaplasia in Stomach. Gastroenterology 2017, 152, 762-766.e7. [CrossRef]

85. Testerman, T.L. Beyond the stomach: An updated view of Helicobacter pyloripathogenesis, diagnosis, and treatment. World J. Gastroenterol. 2014, 20, 12781-12808. [CrossRef]

86. Zavos, C.; Kountouras, J.; Sakkias, G.; Venizelos, I.; Deretzi, G.; Arapoglou, S. Histological Presence of Helicobacter pylori Bacteria in the Trabeculum and Iris of Patients with Primary Open-Angle Glaucoma. Ophthalmic Res. 2012, 47, 150-156. [CrossRef]

87. Al Sayed, A.; Anand, P.S.; Kamath, K.P.; Patil, S.; Preethanath, R.S.; Anil, S. Oral Cavity as an Extragastric Reservoir of Helicobacter pylori. ISRN Gastroenterol. 2014, 2014, 261369. [CrossRef]

88. Payão, S.L.M.; Rasmussen, L.T. Helicobacter pyloriand its reservoirs: A correlation with the gastric infection. World J. Gastrointest. Pharm. 2016, 7, 126-132. [CrossRef]

89. Yee, J.K.C. Are the view of Helicobacter pylori colonized in the oral cavity an illusion? Exp. Mol. Med. 2017, 49, e397. [CrossRef]

90. Czesnikiewicz-Guzik, M.; Bielanski, W.; Guzik, T.J.; Loster, B.; Konturek, S.J. Helicobacter pylori in the oral cavity and its implications for gastric infection, periodontal health, immunology and dyspepsia. J. Physiol. Pharmacol. Off. J. Pol. Physiol. Soc. 2005, 77-89.

91. Veiga, N.; Pereira, C.; Resende, C.; Amaral, O.; Ferreira, M.; Nelas, P.; Chaves, C.; Duarte, J.; Cirnes, L.; Machado, J.C.; et al. Oral and Gastric Helicobacter Pylori: Effects and Associations. PLoS ONE 2015, 10, e0126923. [CrossRef]

92. Malfertheiner, M.V.; Kandulski, A.; Schreiber, J.; Malfertheiner, P. Helicobacter pylori Infection and the Respiratory System: A Systematic Review of the Literature. Digestion 2011, 84, 212-220. [CrossRef] [PubMed]

93. Jahromy, S.H.; Siavoshi, F.; Malekzadeh, R.; Sattari, T.N.; Latifi-Navid, S. Reciprocal impact of host factors andHelicobacter pylorigenotypes on gastric diseases. World J. Gastroenterol. 2015, 21, 9317-9327. [CrossRef] [PubMed]

94. Zabaleta, J. MicroRNA: A Bridge from H. pylori Infection to Gastritis and Gastric Cancer Development. Front. Genet. 2012, 3, 294. [CrossRef] [PubMed]

95. Shih, H.-M.; Hsu, T.-Y.; Chen, C.-Y.; Lin, C.-L.; Kao, C.-H.; Chen, C.-H.; Yang, T.-Y.; Chen, W.-K. Analysis of Patients with Helicobacter pylori Infection and the Subsequent Risk of Developing Osteoporosis after Eradication Therapy: A Nationwide Population-Based Cohort Study. PLoS ONE 2016, 11, e0162645. [CrossRef] [PubMed]

96. Kalantarhormozi, M.R.; Assadi, M.; Vahdat, K.; Asadipooya, K.; Ostovar, A.; Raissi, K.; Darabi, H.; Farrokhi, S.; Dobaradaran, S.; Farrokhnia, M.; et al. Chlamydia pneumoniae and Helicobacter pylori IgG seropositivities are not predictors of osteoporosis-associated bone loss: A prospective cohort study. J. Bone Miner. Metab. 2015, 34, 422-428. [CrossRef] 
97. Chung, Y.H.; Gwak, J.S.; Hong, S.W.; Hyeon, J.H.; Lee, C.M.; Oh, S.W.; Kwon, H. Helicobacter pylori: A Possible Risk Factor for Bone Health. Korean J. Fam. Med. 2015, 36, 239-244. [CrossRef]

98. Figura, N.; Gennari, L.; Merlotti, D.; Lenzi, C.; Campagna, M.S.; Franci, M.B.; Lucani, B.; Trabalzini, L.; Bianciardi, L.; Gonnelli, C.; et al. Prevalence of Helicobacter pylori Infection in Male Patients with Osteoporosis and Controls. Dig. Dis. Sci. 2005, 50, 847-852. [CrossRef]

99. Figura, N.; Gennai, L.; Merlotti, D.; Campagna, M.; Franci, B.; Avanzati, A.; Lucani, B.; Calabro, A.; Lardiello, S.; Nuti, R. H. pylori (HP) infection and osteoporosis: A population based study. In Proceedings of the European Helicobacter Study 23nd International Workshop on Helicobacter Related Bacteria in Chronic Digestive Inflammation and Gastric Cancer, Rotterdam, The Netherlands, 16-18 September 2010; Blackwell Publishing Ltd., Helicobacter: Rotterdam, The Netherlands, 2010; pp. 334-335.

100. Cooper, C.; Cole, Z.A.; Holroyd, C.R.; Earl, S.C.; Harvey, N.C.; Dennison, E.M.; Melton, L.J.; Cummings, S.R.; Kanis, J.A.; The IOF CSA Working Group on Fracture Epidemiology. Secular trends in the incidence of hip and other osteoporotic fractures. Osteoporos. Int. 2011, 22, 1277-1288. [CrossRef]

101. Ballane, G.; Cauley, A.J.; Luckey, M.M.; Fuleihan, G.E.-H. Secular Trends in Hip Fractures Worldwide: Opposing Trends East Versus West. J. Bone Miner. Res. 2014, 29, 1745-1755. [CrossRef]

102. Ballane, G.; Cauley, J.A.; Luckey, M.M.; Fuleihan, G.E.-H. Worldwide prevalence and incidence of osteoporotic vertebral fractures. Osteoporos. Int. 2017, 28, 1531-1542. [CrossRef] [PubMed]

103. Cheung, C.-L.; Bin Ang, S.; Chadha, M.; Chow, E.S.-L.; Chung, Y.-S.; Hew, F.L.; Jaisamrarn, U.; Ng, H.; Takeuchi, Y.; $\mathrm{Wu}, \mathrm{C} .-\mathrm{H} . ;$ et al. An updated hip fracture projection in Asia: The Asian Federation of Osteoporosis Societies study. Osteoporos. Sarcopenia 2018, 4, 16-21. [CrossRef] [PubMed]

104. Thambiah, S.C.; Yeap, S.S. Osteoporosis in South-East Asian Countries. Clin. Biochem. Rev. 2020, 41, $29-40$. [PubMed]

105. Ozdem, S.; Akcam, M.; Yilmaz, A.; Gultekin, M.; Artan, R. Biochemical Markers of Bone Metabolism in Children with Helicobacter pylori Infection. Dig. Dis. Sci. 2007, 52, 967-972. [CrossRef] [PubMed]

106. Asaoka, D.; Nagahara, A.; Shimada, Y.; Matsumoto, K.; Ueyama, H.; Matsumoto, K.; Nakagawa, Y.; Takeda, T.; Tanaka, I.; Sasaki, H.; et al. Risk factors for osteoporosis in Japan: Is it associated with Helicobacter pylori? Clin. Risk Manag. 2015, 11, 381-391. [CrossRef] [PubMed]

107. Kakehasi, A.M.; Mendes, C.M.C.; Coelho, L.G.V.; Castro, L.P.; Barbosa, A.J.A. The presence of Helicobacter Pylori in postmenopausal women is not a factor to the decrease of bone mineral density. Arq. Gastroenterol. 2007, 44, 266-270. [CrossRef] [PubMed]

108. Kakehasi, A.M.; Rodrigues, C.B.; Carvalho, A.V.; Barbosa, A.J.A. Chronic Gastritis and Bone Mineral Density in Women. Dig. Dis. Sci. 2008, 54, 819-824. [CrossRef]

109. Akkaya, N.; Akkaya, S.; Polat, Y.; Turk, M.; Turk, T.; Turhal, E.; Sahin, F. Helicobacter pylori seropositivity in fibromyalgia syndrome. Clin. Rheumatol. 2011, 30, 43-49. [CrossRef]

110. Asaoka, D.; Nagahara, A.; Hojo, M.; Sasaki, H.; Shimada, Y.; Yoshizawa, T.; Osada, T.; Watanabe, S. The Relationship between H. pyloriInfection and Osteoporosis in Japan. Gastroenterol. Res. Pract. 2014, 2014, 340765. [CrossRef]

111. Lin, S.-C.; Koo, M.; Tsai, K.-W. Association betweenHelicobacter pyloriInfection and Risk of Osteoporosis in Elderly Taiwanese Women with Upper Gastrointestinal Diseases: A Retrospective Patient Record Review. Gastroenterol. Res. Pract. 2014, 2014, 814756. [CrossRef]

112. Mizuno, S.; Matsui, D.; Watanabe, I.; Ozaki, E.; Kuriyama, N.; Watanabe, Y. Serologically Determined Gastric Mucosal Condition Is a Predictive Factor for Osteoporosis in Japanese Men. Dig. Dis. Sci. 2015, 60, 2063-2069. [CrossRef] [PubMed]

113. Fotouk-Kiai, M.; Hoseini, S.R.; Meftah, N.; Ghadimi, R.; Bijani, A.; Noreddini, H.; Nematollahi, H.; Shokri-Shirvani, J. Relationship between Helicobacter pylori infection (HP) and bone mineral density (BMD) in elderly people. Casp. J. Intern. Med. 2015, 6, 62-66.

114. Chen, L.-W.; Chen, F.-P.; Hsieh, C.-W.; Kuo, S.-F.; Chien, R.-N. Analysis of the associations among Helicobacter pylori infection, adiponectin, leptin, and 10-year fracture risk using the fracture risk assessment tool: A cross-sectional community-based study. PLoS ONE 2017, 12, e0175365. [CrossRef]

115. Chinda, D.; Shimoyama, T.; Iino, C.; Matsuzaka, M.; Nakaji, S.; Fukuda, S. Decrease of Estradiol and Several Lifestyle Factors, but Not Helicobacter pylori Infection, Are Significant Risks for Osteopenia in Japanese Females. Digestion 2017, 96, 103-109. [CrossRef] [PubMed] 
116. Abdolahi, N.; Aghaei, M.; Naghdi, M. AB0850 Helicobacter pylori infection and osteoporosis in post monopausal women. Ann. Eur. Congr. Rheumatol. 2017, 76, 1354.

117. Pan, B.-L.; Huang, C.-F.; Chuah, S.-K.; Chiang, J.-C.; Loke, S.-S. Relationship between Helicobacter pylori infection and bone mineral density: A retrospective cross-sectional study. BMC Gastroenterol. 2018, 18, 54. [CrossRef]

118. Chinda, D.; Shimoyama, T.; Sawada, K.; Iino, C.; Sakuraba, H.; Nakaji, S.; Fukuda, S. Lifestyle Factors Rather Than Helicobacter pylori Infection or Estradiol Level are Associated With Osteopenia in Japanese Men. Am. J. Men's Health 2019, 13, 1557988319848219. [CrossRef] [PubMed]

119. Santavirta, S.; Konttinen, Y.T.; Heliövaara, M.; Knekt, P.; Lüthje, P.; Aromaa, A. Determinants of osteoporotic thoracic vertebral fracture. Acta Orthop. Scand. 1992, 63, 198-202. [CrossRef] [PubMed]

120. Sawicki, A.; Regula, A.; Godwod, K.; Debinski, A. Peptic ulcer disease and calcium intake as risk factors of osteoporosis in women. Osteoporos. Int. 2003, 14, 983-986. [CrossRef] [PubMed]

121. Singh, J.A.; Lewallen, D.G. Association of peptic ulcer disease and pulmonary disease with risk of periprosthetic fracture after primary total knee arthroplasty. Arthritis Rheum. 2011, 63, 1471-1476. [CrossRef] [PubMed]

122. Singh, J.A.; Lewallen, D.G. Peptic ulcer disease and heart disease are associated with periprosthetic fractures after total hip replacement. Acta Orthop. 2012, 83, 353-359. [CrossRef] [PubMed]

123. Wu, C.-H.; Tung, Y.-C.; Chaiter, Y.; Lu, Y.-Y.; Su, Y.-F.; Tsai, T.-H.; Kuo, K.-L.; Lin, C.-L. Increased Risk of Osteoporosis in Patients With Peptic Ulcer Disease. Medcine 2016, 95, e3309. [CrossRef] [PubMed]

124. Yoon, P.H.; An, S.J.; Jeong, S.-H.; Yang, Y.-J.; Hong, Y.-P. Association between Peptic Ulcer Disease and Osteoporosis: The Population-Based Longitudinal Cohort Study in Korea. Int. J. Environ. Res. Public Health 2019, 16, 2777. [CrossRef] [PubMed]

125. Choi, H.G.; Rhim, C.C.; Yoon, J.Y.; Park, B.J.; Min, C.Y.; Lee, S.W. Increased risk of osteoporosis in patients with peptic ulcer: A follow-up study using a national sample cohort. Arch. Osteoporos. 2019, 14, 105. [CrossRef]

126. Melton, L.J.; Crowson, C.S.; Khosla, S.; O'Fallon, W.M. Fracture risk after surgery for peptic ulcer disease: A population-based cohort study. Bone 1999, 25, 61-67. [CrossRef]

127. Jeffery, P.L.; McGuckin, M.A.; Linden, S.K. Endocrine impact of Helicobacter pylori: Focus on ghrelin and ghrelin o-acyltransferase. World J. Gastroenterol. 2011, 17, 1249-1260. [CrossRef]

128. Massironi, S.; Cavalcoli, F.; Rossi, R.E.; Conte, D.; Spampatti, M.P.; Ciafardini, C.; Verga, U.; Beck-Peccoz, P.; Peracchi, M. Chronic autoimmune atrophic gastritis associated with primary hyperparathyroidism: A transversal prospective study. Eur. J. Endocrinol. 2013, 168, 755-761. [CrossRef]

129. Lahner, E.; Annibale, B. Pernicious anemia: New insights from a gastroenterological point of view. World J. Gastroenterol. 2009, 15, 5121-5128. [CrossRef]

130. Toh, B.-H.; Kyaw, T.; Taylor, R.; Pollock, W.; Schlumberger, W. Parietal cell antibody identified by ELISA is superior to immunofluorescence, rises with age and is associated with intrinsic factor antibody. Autoimmunity 2012, 45, 527-532. [CrossRef]

131. Tozzoli, R.; Kodermaz, G.; Perosa, A.R.; Tampoia, M.; Zucano, A.; Antico, A.; Bizzaro, N. Autoantibodies to parietal cells as predictors of atrophic body gastritis: A five-year prospective study in patients with autoimmune thyroid diseases. Autoimmun. Rev. 2010, 10, 80-83. [CrossRef]

132. Abe, T.; Kodama, M.; Murakami, K.; Matsunari, O.; Mizukami, K.; Inoue, K.; Uchida, M.; Okimoto, T.; Fujioka, T.; Uchida, T.; et al. Impact of Helicobacter pylori CagA diversity on gastric mucosal damage: An immunohistochemical study of East-Asian-type CagA. J. Gastroenterol. Hepatol. 2011, 26, 688-693. [CrossRef] [PubMed]

133. Sonnenberg, A.; Lash, R.H.; Genta, R.M. A National Study of Helicobactor pylori Infection in Gastric Biopsy Specimens. Gastroenterology 2010, 139, 1894-1901.e2. [CrossRef]

134. Heidari, B. Helicobacter pylori infection and osteoporosis in elderly patients. Casp. J. Intern. Med. 2015, 6, $48-50$.

135. Aasarød, K.M.; Mosti, M.P.; Stunes, A. (Astrid); Reseland, J.E.; Basso, T.; Syversen, U.; Fossmark, R. Impaired skeletal health in patients with chronic atrophic gastritis. Scand. J. Gastroenterol. 2016, 51, 774-781.

136. Kim, H.W.; Kim, Y.-H.; Han, K.; Nam, G.E.; Kim, G.S.; Han, B.-D.; Lee, A.; Ahn, J.Y.; Ko, B.J. Atrophic Gastritis: A Related Factor for Osteoporosis in Elderly Women. PLoS ONE 2014, 9, e101852. [CrossRef] [PubMed] 
137. Jacob, L.; Hadji, P.; Kostev, K. The use of proton pump inhibitors is positively associated with osteoporosis in postmenopausal women in Germany. Climacteric 2016, 19, 478-481. [CrossRef] [PubMed]

138. Kim, A.-S.; Ko, H.-J. Atrophic Gastritis as a Risk Factor for Bone Loss in Premenopausal Women in Their 40s: A Retrospective Cohort Study. Calcif. Tissue Int. 2018, 104, 34-41. [CrossRef]

139. Muhsen, K.; Sinnreich, R.; Beer-Davidson, G.; Nassar, H.; Cohen, D.; Kark, J.D. Sero-prevalence of Helicobacter pylori CagA immunoglobulin $\mathrm{G}$ antibody, serum pepsinogens and haemoglobin levels in adults. Sci. Rep. 2018, 8, 17616. [CrossRef]

140. Betesh, A.L.; Ana, C.A.S.; Cole, J.A.; Fordtran, J.S. Is achlorhydria a cause of iron deficiency anemia? Am. J. Clin. Nutr. 2015, 102, 9-19. [CrossRef]

141. Amedei, A.; Bergman, M.P.; Appelmelk, B.J.; Azzurri, A.; Benagiano, M.; Tamburini, C.; Van Der Zee, R.; Telford, J.L.; Vandenbroucke-Grauls, C.M.J.E.; D’Elios, M.M.; et al. Molecular Mimicry between Helicobacter pylori Antigens and $\mathrm{H}+, \mathrm{K}+-$ Adenosine Triphosphatase in Human Gastric Autoimmunity. J. Exp. Med. 2003, 198, 1147-1156. [CrossRef]

142. Berman, A.G.; Organ, J.M.; Allen, M.R.; Wallace, J. Muscle contraction induces osteogenic levels of cortical bone strain despite muscle weakness in a mouse model of Osteogenesis Imperfecta. Bone 2020, 132, 115061. [CrossRef]

143. Weck, M.N.; Gao, L.; Brenner, H. Helicobacter pylori Infection and Chronic Atrophic Gastritis. Epidemiology 2009, 20, 569-574. [CrossRef]

144. Veijola, L.; Oksanen, A.M.; Sipponen, P.I.; Rautelin, H.I.K. Association of autoimmune type atrophic corpus gastritis with Helicobacter pylori infection. World J. Gastroenterol. 2010, 16, 83-88.

145. Demiroğlu, H.; Dündar, S. Pernicious anaemia patients should be screened for iron deficiency during follow up. N. Z. Med. J. 1997, 110, 147-148.

146. Dickey, W. Iron deficiency, gastric atrophy and Helicobacter pylori. Dig. Liver Dis. 2002, 34, 313-315. [CrossRef]

147. Hershko, C.; Ronson, A.; Souroujon, M.; Maschler, I.; Heyd, J.; Patz, J. Variable hematologic presentation of autoimmune gastritis: Age-related progression from iron deficiency to cobalamin depletion. Blood 2006, 107, 1673-1679. [CrossRef]

148. Hershko, C.; Patz, J.; Ronson, A. The anemia of achylia gastrica revisited. Blood Cells Mol. Dis. 2007, 39, 178-183. [CrossRef]

149. Cavalcoli, F.; Zilli, A.; Conte, D.; Massironi, S. Micronutrient deficiencies in patients with chronic atrophic autoimmune gastritis: A review. World J. Gastroenterol. 2017, 23, 563-572. [CrossRef]

150. Çă̆daş, K.; Soykan, I. Utility of a laboratory score in the prediction of gastric emptying in autoimmune gastritis patients. Acta Clin. Belg. 2017, 73, 75-79.

151. Çă̆daş, K.; Soykan, I. Polyautoimmunity in autoimmune gastritis. Eur. J. Intern. Med. 2016, 31, 79-83. [CrossRef]

152. Carmel, R. Cobalamin, the stomach, and aging. Am. J. Clin. Nutr. 1997, 66, 750-759. [CrossRef] [PubMed]

153. Kim, G.; Kim, C.-H.; Park, J.; Lee, K.-U.; Park, C. Effects of vitamin B12 on cell proliferation and cellular alkaline phosphatase activity in human bone marrow stromal osteoprogenitor cells and UMR106 osteoblastic cells. Metabolism 1996, 45, 1443-1446. [CrossRef]

154. Tucker, K.L.; Hannan, M.T.; Qiao, N.; Jacques, P.F.; Selhub, J.; Cupples, L.A.; Kiel, D.P. Low plasma vitamin B12 is associated with lower BMD: The Framingham Osteoporosis Study. J. Bone Miner. Res. 2005, 20, 152-158. [CrossRef]

155. Sato, Y.; Honda, Y.; Iwamoto, J.; Kanoko, T.; Satoh, K. Effect of Folate and Mecobalamin on Hip Fractures in Patients with Stroke. JAMA 2005, 293, 1082-1088. [CrossRef] [PubMed]

156. McLean, R.R.; Jacques, P.F.; Selhub, J.; Fredman, L.; Tucker, K.L.; Samelson, E.J.; Kiel, D.P.; Cupples, L.A.; Hannan, M.T. Plasma B vitamins, homocysteine, and their relation with bone loss and hip fracture in elderly men and women. J. Clin. Endocrinol. Metab. 2008, 93, 2206-2212. [CrossRef] [PubMed]

157. Swart, K.M.; Van Schoor, N.M.; Lips, P. Vitamin B12, Folic Acid, and Bone. Curr. Osteoporos. Rep. 2013, 11, 213-218. [CrossRef]

158. Lewerin, C.; Nilsson-Ehle, H.; Jacobsson, S.; Johansson, H.; Sundh, V.; Karlsson, M.K.; Ljunggren, O.; Lorentzon, M.; Kanis, J.; Lerner, U.H.; et al. Low holotranscobalamin and cobalamins predict incident fractures in elderly men: The MrOS Sweden. Osteoporos. Int. 2013, 25, 131-140. [CrossRef] [PubMed] 
159. Dai, Z.; Koh, W.-P. B-Vitamins and Bone Health-A Review of the Current Evidence. Nutrients 2015, 7, 3322-3346. [CrossRef]

160. Saito, M.; Marumo, K. The Effects of Homocysteine on the Skeleton. Curr. Osteoporos. Rep. 2018, 16, 554-560. [CrossRef]

161. Su, Y.; Elshorbagy, A.; Turner, C.; Refsum, H.; Chan, R.; Kwok, T.C.Y. Circulating amino acids are associated with bone mineral density decline and ten-year major osteoporotic fracture risk in older community-dwelling adults. Bone 2019, 129, 115082. [CrossRef]

162. Merriman, N.A.; Putt, M.E.; Metz, D.C.; Yang, Y.-X. Hip Fracture Risk in Patients with a Diagnosis of Pernicious Anemia. Gastroenterology 2010, 138, 1330-1337. [CrossRef] [PubMed]

163. Goerss, J.B.; Kim, C.H.; Atkinson, E.J.; Eastell, R.; O'Fallon, W.M.; Melton, L.J. Risk of fractures in patients with pernicious anemia. J. Bone Miner. Res. 2009, 7, 573-579. [CrossRef] [PubMed]

164. Yang, G.-T.; Zhao, H.-Y.; Kong, Y.; Sun, N.-N.; Dong, A.-Q. Correlation between serum vitamin B12 level and peripheral neuropathy in atrophic gastritis. World J. Gastroenterol. 2018, 24, 1343-1352. [CrossRef] [PubMed]

165. Melton, M.E.; Kochman, M.L. Reversal of severe osteoporosis with vitamin B12 and etidronate therapy in a patient with pernicious anemia. Metabolism 1994, 43, 468-469. [CrossRef]

166. Lopez, M.G.; Baron, J.A.; Omsland, T.K.; Søgaard, A.J.; Meyer, H.E. Homocysteine-Lowering Treatment and the Risk of Fracture: Secondary Analysis of a Randomized Controlled Trial and an Updated Meta-Analysis. JBMR Plus 2018, 2, 295-303. [CrossRef]

167. Stone, K.L.; Lui, L.-Y.; Christen, W.G.; Troen, A.M.; Bauer, D.C.; Kado, D.; Schambach, C.; Cummings, S.R.; Manson, J.E. Effect of Combination Folic Acid, Vitamin B6, and Vitamin B12Supplementation on Fracture Risk in Women: A Randomized, Controlled Trial. J. Bone Miner. Res. 2017, 32, 2331-2338. [CrossRef]

168. Massironi, S.; Cavalcoli, F.; Zilli, A.; Del Gobbo, A.; Ciafardini, C.; Bernasconi, S.; Felicetta, I.; Conte, D.; Peracchi, M. Relevance of vitamin D deficiency in patients with chronic autoimmune atrophic gastritis: A prospective study. BMC Gastroenterol. 2018, 18, 172. [CrossRef]

169. Cesari, M.; Pahor, M.; Lauretani, F.; Penninx, B.W.H.J.; Bartali, B.; Russo, R.; Cherubini, A.; Woodman, R.; Bandinelli, S.; Guralnik, J.M.; et al. Bone density and hemoglobin levels in older persons: Results from the InCHIANTI study. Osteoporos. Int. 2004, 16, 691-699. [CrossRef]

170. Laudisio, A.; Marzetti, E.; Pagano, F.; Bernabei, R.; Zuccalà, G. Haemoglobin levels are associated with bone mineral density in the elderly: A population-based study. Clin. Rheumatol. 2008, 28, 145-151. [CrossRef]

171. Chen, Z.; Thomson, C.A.; Aickin, M.; Nicholas, J.S.; Van Wyck, D.; Lewis, C.E.; Cauley, J.A.; Bassford, T. Short list of Women's Health Initiative Investigators The relationship between incidence of fractures and anemia in older multiethnic women. J. Am. Geriatr. Soc. 2010, 58, 2337-2344. [CrossRef]

172. Korkmaz, U.; Korkmaz, N.; Yazıc1, S.; Erkan, M.; Baki, A.E.; Yazici, M.; Özhan, H.; Ataoglu, S.; Yazici, S. Anemia as a risk factor for low bone mineral density in postmenopausal Turkish women. Eur. J. Intern. Med. 2012, 23, 154-158. [CrossRef] [PubMed]

173. Rutten, E.P.; Franssen, F.M.E.; Spruit, M.A.; Wouters, E.F.M. Anemia is associated with bone mineral density in chronic obstructive pulmonary disease. Copd J. Chronic Obs. Pulm. Dis. 2012, 10, 286-292. [CrossRef] [PubMed]

174. Oh, Y.H.; Moon, J.H.; Cho, B. Association between Hemoglobin Level and Bone Mineral Density in Korean Adults. J. Bone Metab. 2017, 24, 161-173. [CrossRef]

175. Valderrábano, R.J.; Lee, J.; Lui, L.-Y.; Hoffman, A.R.; Cummings, S.R.; Orwoll, E.S.; Wu, J.Y.; Osteoporotic Fractures in Men (MrOS) Study Research Group. Older Men with Anemia Have Increased Fracture Risk Independent of Bone Mineral Density. J. Clin. Endocrinol. Metab. 2017, 102, 2199-2206.

176. Chuang, M.-H.; Chuang, T.-L.; Koo, M.; Wang, Y.-F. Low Hemoglobin Is Associated with Low Bone Mineral Density and High Risk of Bone Fracture in Male Adults: A Retrospective Medical Record Review Study. Am. J. Men's Health 2019, 13, 1557988319850378. [CrossRef]

177. Valderrábano, R.J.; Wu, J.Y. Bone and blood interactions in human health and disease. Bone 2019, 119, 65-70. [CrossRef]

178. Lu, M.; Liu, Y.; Shao, M.; Tesfaye, G.C.; Yang, S. Associations of Iron Intake, Serum Iron and Serum Ferritin with Bone Mineral Density in Women: The National Health and Nutrition Examination Survey, 2005-2010. Calcif. Tissue Int. 2019, 106, 232-238. [CrossRef] 
179. Ohkusa, T.; Fujiki, K.; Takashimizu, I.; Kumagai, J.; Tanizawa, T.; Eishi, Y.; Yokoyama, T.; Watanabe, M. Improvement in atrophic gastritis and intestinal metaplasia in patients in whom Helicobacter pylori was eradicated. Ann. Intern. Med. 2001, 134, 380-386. [CrossRef]

180. Ito, M.; Haruma, K.; Kamada, T.; Mihara, M.; Kim, S.; Kitadai, Y.; Sumii, M.; Tanaka, S.; Yoshihara, M.; Chayama, K. Helicobacter pylori eradication therapy improves atrophic gastritis and intestinal metaplasia: A 5-year prospective study of patients with atrophic gastritis. Aliment. Pharm. 2002, 16, 1449-1456. [CrossRef]

181. Hwang, Y.J.; Kim, N.; Lee, H.S.; Lee, J.B.; Choi, Y.J.; Yoon, H.; Shin, C.M.; Park, Y.S.; Lee, D.H. Reversibility of atrophic gastritis and intestinal metaplasia after Helicobacter pylori eradication-A prospective study for up to 10 years. Aliment. Pharm. 2018, 47, 380-390. [CrossRef]

182. Sierra, R.; Une, C.; Ramírez, V.; Alpízar-Alpízar, W.; González, I.M.; Ramírez, J.A.; De Mascarel, A.; Cuenca, P.; Perez, G.I.P.; Mégraud, F. Relation of atrophic gastritis with Helicobacter pylori-CagA+ and interleukin-1 gene polymorphisms. World J. Gastroenterol. 2008, 14, 6481-6487. [CrossRef]

183. Gao, L.; Weck, M.N.; Nieters, A.; Brenner, H. Inverse association between a pro-inflammatory genetic profile and Helicobacter pylori seropositivity among patients with chronic atrophic gastritis: Enhanced elimination of the infection during disease progression? Eur. J. Cancer 2009, 45, 2860-2866. [CrossRef]

184. IAR. Schistosomes, Liver Flukes and Helicobacter pylori; International Agency for Research on Cancer: Lyon, France, 1994; Volume 61, pp. 1-241.

185. Kamangar, F.; Dawsey, S.M.; Blaser, M.J.; Perez-Perez, G.I.; Pietinen, P.; Newschaffer, C.J.; Abnet, C.C.; Albanes, D.; Virtamo, J.; Taylor, P.R. Opposing Risks of Gastric Cardia and Noncardia Gastric Adenocarcinomas Associated with Helicobacter pylori Seropositivity. J. Natl. Cancer Inst. 2006, 98, 1445-1452. [CrossRef]

186. Amieva, M.; Peek, R.M. Pathobiology of Helicobacter pylori-Induced Gastric Cancer. Gastroenterology 2016, 150, 64-78. [CrossRef]

187. Bakhti, S.Z.; Latifi-Navid, S.; Safaralizadeh, R. Helicobacter pylori-related risk predictors of gastric cancer: The latest models, challenges, and future prospects. Cancer Med. 2020, 9, 4808-4822. [CrossRef]

188. Vohlonen, I.; Pukkala, E.; Malila, N.; Härkönen, M.; Hakama, M.; Koistinen, V.; Sipponen, P. Risk of gastric cancer in Helicobacter pylori infection in a 15-year follow-up. Scand. J. Gastroenterol. 2016, 51, 1159-1164. [CrossRef]

189. Nomura, A.M.Y.; Lee, J.; Stemmermann, G.N.; Nomura, R.Y.; Perez, G.I.P.; Blaser, M.J. Helicobacter pyloriCagA Seropositivity and Gastric Carcinoma Risk in a Japanese American Population. J. Infect. Dis. 2002, 186, 1138-1144. [CrossRef]

190. Kusters, J.G.; van Vliet, A.H.; Kuipers, E.J. Pathogenesis of Helicobacter pylori infection. Clin. Microbiol Rev. 2006, 19, 449-490. [CrossRef]

191. Park, J.Y.; Forman, D.; Waskito, L.A.; Yamaoka, Y.; Crabtree, J.E. Epidemiology of Helicobacter pylori and CagA-Positive Infections and Global Variations in Gastric Cancer. Toxins 2018, 10, 163. [CrossRef]

192. Liedman, B.; Henningsson, A.; Mellström, D.; Lundell, L. Changes in Bone Metabolism and Body Composition After Total Gastrectomy. Dig. Dis. Sci. 2000, 45, 819-824. [CrossRef]

193. Lai, S.-W.; Kuo, Y.-H.; Lai, S.-W. Increased risk of osteoporotic fractures in patients with gastric cancer and post-gastrectomy. Bone 2020, 132, 115185. [CrossRef]

194. Zittel, T.T.; Zeeb, B.; Maier, G.W.; Kaiser, G.W.; Zwirner, M.; Liebich, H.; Starlinger, M.; Becker, H.D. High prevalence of bone disorders after gastrectomy. Am. J. Surg. 1997, 174, 431-438. [CrossRef]

195. Kanis, J.; Johnell, O.; Gullberg, B.; Allander, E.; Elffors, L.; Ranstam, J.; Dequeker, J.; Dilsen, G.; Gennari, C.; Vaz, A.L.; et al. Risk Factors for Hip Fracture in Men from Southern Europe: The MEDOSStudy. Osteoporos. Int. 1999, 9, 45-54. [CrossRef]

196. Lim, J.S.; Kim, S.B.; Bang, H.Y.; Cheon, G.J.; Lee, J.I. High prevalence of osteoporosis in patients with gastric adenocarcinoma following gastrectomy. World J. Gastroenterol. 2007, 13, 6492-6497. [CrossRef]

197. Baek, K.H.; Jeon, H.M.; Lee, S.S.; Lim, D.-J.; Oh, K.W.; Lee, W.-Y.; Rhee, E.-J.; Han, J.H.; Cha, B.Y.; Lee, K.W.; et al. Short-term changes in bone and mineral metabolism following gastrectomy in gastric cancer patients. Bone 2008, 42, 61-67. [CrossRef]

198. Lim, J.S.; Lee, J.-I. Prevalence, Pathophysiology, Screening and Management of Osteoporosis in Gastric Cancer Patients. J. Gastric Cancer 2011, 11, 7-15. [CrossRef] 
199. Krupski, W.; Tatara, M.R.; Bury, P.; Szabelska, A.; Charuta, A.; Maciejewski, R.; Wallner, G.; Dabrowski, A. Negative Effects of Total Gastrectomy on Bone Tissue Metabolism and Volumetric Bone Mineral Density (vBMD) of Lumbar Spine in 1-Year Study in Men. Medcine 2016, 95, e2817. [CrossRef]

200. Oh, H.J.; Lim, C.-H.; Yoon, B.-H.; Yoon, S.B.; Baeg, M.K.; Kim, W.C.; Choi, M.-G.; Park, J.M.; Choi, M.-G.; Yoo, H.M.; et al. Fracture after gastrectomy for gastric cancer: A long-term follow-up observational study. Eur. J. Cancer 2017, 72, 28-36. [CrossRef]

201. Yoo, S.H.; Lee, J.A.; Kang, S.Y.; Kim, Y.S.; Sunwoo, S.; Kim, B.S.; Yook, J.-H. Risk of osteoporosis after gastrectomy in long-term gastric cancer survivors. Gastric Cancer 2017, 21, 720-727. [CrossRef]

202. Noh, H.M.; Yoo, J.-H.; Jeong, J.Y.; Park, Y.S. Bone mineral density after treatment for gastric cancer. Medcine 2018, 97, e9582. [CrossRef]

203. Seo, G.H.; Kang, H.Y.; Choe, E.K. Osteoporosis and fracture after gastrectomy for stomach cancer. Medcine 2018, 97, e0532. [CrossRef]

204. Iki, M.; Fujita, Y.; Kouda, K.; Yura, A.; Tachiki, T.; Tamaki, J.; Sato, Y.; Moon, J.-S.; Hamada, M.; Kajita, E.; et al. Increased risk of osteoporotic fracture in community-dwelling elderly men 20 or more years after gastrectomy: The Fujiwara-kyo Osteoporosis Risk in Men (FORMEN) Cohort Study. Bone 2019, 127, 250-259. [CrossRef]

205. Inoue, K.; Shiomi, K.; Higashide, S.; Kan, N.; Nio, Y.; Tobe, T.; Shigeno, C.; Konishi, J.; Okumurat, H.; Yamamuro, T.; et al. Metabolic bone disease following gastrectomy: Assessment by dual energy X-ray absorptiometry. BJS 1992, 79, 321-324. [CrossRef] [PubMed]

206. Heiskanen, J.T.; Kröger, H.; Pääkkönen, M.; Parviainen, M.T.; Lamberg-Allardt, C.; Alhava, E. Bone mineral metabolism after total gastrectomy. Bone 2001, 28, 123-127. [CrossRef]

207. Jeong, S.-M.; Shin, N.W.; Lee, J.E.; Jin, S.-M.; Kim, S. Increased Risk of Osteoporosis in Gastric Cancer Survivors Compared to General Population Control: A Study with Representative Korean Population. Cancer Res. Treat. 2018, 51, 530-537. [CrossRef] [PubMed]

208. Shin, N.W.; Suh, B.; Lim, H.; Suh, Y.-S.; Choi, Y.J.; Jeong, S.-M.; Yun, J.M.; Song, S.O.; Park, Y. Increased Risk of Osteoporotic Fracture in Postgastrectomy Gastric Cancer Survivors Compared With Matched Controls: A Nationwide Cohort Study in Korea. Am. J. Gastroenterol. 2019, 114, 1735-1743. [CrossRef] [PubMed]

209. Tachiki, T.; Kouda, K.; Dongmei, N.; Tamaki, J.; Iki, M.; Kitagawa, J.; Takahira, N.; Sato, Y.; Kajita, E.; Fujita, Y.; et al. Muscle strength is associated with bone health independently of muscle mass in postmenopausal women: The Japanese population-based osteoporosis study. J. Bone Miner. Metab. 2017, 37, 53-59. [CrossRef]

210. Atsumi, Y.; Rino, Y.; Wada, H.; Kitani, Y.; Ozawa, Y.; Aoyama, T.; Oshima, T.; Yukawa, N.; Yoshikawa, T.; Masuda, M. Changes in bone metabolism after gastric cancer surgery in male patients: A prospective observational study. Gastric Cancer 2018, 22, 237-243. [CrossRef]

211. Imawari, M.; Kozawa, K.; Akanuma, Y.; Koizumi, S.; Itakura, H.; Kosaka, K. Serum 25-hydroxyvitamin D and vitamin D-binding protein levels and mineral metabolism after partial and total gastrectomy. Gastroenterology 1980, 79, 255-258. [CrossRef]

212. Ichikawa, C.; Takiguchi, N.; Koda, K.; Oda, K.; Suzuki, H.; Miyazaki, M. Early phase metabolic bone disorders after gastrectomy: Influence of active vitamin D treatment. Dig. Dis. Sci. 2002, 47, 1886-1890. [CrossRef]

213. Rino, Y.; Takanashi, Y.; Yamamoto, Y.; Inagaki, D.; Kawamoto, M.; Harada, H.; Ashida, A.; Wada, H.; Yamada, R.; Ohshima, T.; et al. Bone disorder and vitamin D after gastric cancer surgery. Hepatogastroenterology 2007, 54, 1596-1600.

214. Climent, M.; Pera, M.; Aymar, I.; Ramón, J.M.; Grande, L.; Nogués, X. Bone health in long-term gastric cancer survivors: A prospective study of high-dose vitamin D supplementation using an easy administration scheme. J. Bone Miner. Metab. 2017, 36, 462-469. [CrossRef]

215. Ehrhart, N.; Eurell, J.A.C.; Tommasini, M.; Constable, P.D.; Johnson, A.L.; Feretti, A. Effect of cisplatin on bone transport osteogenesis in dogs. Am. J. Veter Res. 2002, 63, 703-711. [CrossRef]

216. Xian, C.J.; Cool, J.C.; Pyragius, T.; Foster, B.K. Damage and recovery of the bone growth mechanism in young rats following 5-fluorouracil acute chemotherapy. J. Cell. Biochem. 2006, 99, 1688-1704. [CrossRef]

217. Stava, C.J.; Jimenez, C.; Hu, M.I.; Vassilopoulou-Sellin, R. Skeletal sequelae of cancer and cancer treatment. J. Cancer Surviv. 2009, 3, 75-88. [CrossRef]

218. Yaprak, G.; Gemici, C.; Temizkan, S.; Ozdemir, S.; Dogan, B.C.; Seseogullari, O.O. Osteoporosis development and vertebral fractures after abdominal irradiation in patients with gastric cancer. BMC Cancer 2018, 18, 972. [CrossRef] 
219. Lee, Y.-C.; Chiang, T.-H.; Chou, C.-K.; Tu, Y.-K.; Liao, W.-C.; Wu, M.-S.; Graham, D.Y. Association Between Helicobacter pylori Eradication and Gastric Cancer Incidence: A Systematic Review and Meta-analysis. Gastroenterology 2016, 150, 1113-1124.e5. [CrossRef]

220. Sugano, K. (Kentaro) Effect of Helicobacter pylori eradication on the incidence of gastric cancer: A systematic review and meta-analysis. Gastric Cancer 2018, 22, 435-445. [CrossRef]

221. Ding, S.-Z. Global whole family based-Helicobacter pylori eradication strategy to prevent its related diseases and gastric cancer. World J. Gastroenterol. 2020, 26, 995-1004. [CrossRef]

222. Ford, A.C.; Yuan, Y.; Moayyedi, P. Helicobacter pylori eradication therapy to prevent gastric cancer: Systematic review and meta-analysis. Gut 2020, (Epub ahead of print). [CrossRef] [PubMed]

223. Papagiannakis, P.; Michalopoulos, C.; Papalexi, F.; Dalampoura, D.; Diamantidis, M.D. The role of Helicobacter pylori infection in hematological disorders. Eur. J. Intern. Med. 2013, 24, 685-690. [CrossRef] [PubMed]

224. Vicari, J.J.; Peek, R.M.; Falk, G.W.; Goldblum, J.R.; Easley, K.A.; Schnell, J.; Perez-Perez, G.I.; Halter, S.A.; Rice, T.W.; Blaser, M.J.; et al. The seroprevalence of cagA-positive Helicobacter pylori strains in the spectrum of gastroesophageal reflux disease. Gastroenterology 1998, 115, 50-57. [CrossRef]

225. Vaezi, M.F.; Falk, G.W.; Peek, R.M.; Vicari, J.J.; Goldblum, J.R.; Perez-Perez, G.I.; Rice, T.W.; Blaser, M.J.; Richter, J.E. CagA-positive strains of Helicobacter pylori may protect against Barrett's esophagus. Am. J. Gastroenterol. 2000, 95, 2206-2211. [CrossRef]

226. Queiroz, D.M.M.; Guerra, J.B.; Rocha, G.A.; Rocha, A.M.C.; Santos, A.; De Oliveira, A.G.; Cabral, M.M.D.A.; Nogueira, A.M.M.F.; De Oliveira, C.A. IL1B and IL1RN polymorphic genes and Helicobacter pylori cagA strains decrease the risk of reflux esophagitis. Gastroenterology 2004, 127, 73-79. [CrossRef] [PubMed]

227. Corley, D.A.; Kubo, A.; Levin, T.R.; Block, G.; Habel, L.; Rumore, G.; Quesenberry, C.; Buffler, P.; Parsonnet, J. Helicobacter pylori and gastroesophageal reflux disease: A case-control study. Helicobacter 2008, 13, 352-360. [CrossRef]

228. Ghoshal, U.C.; Chourasia, D. Gastroesophageal Reflux Disease and Helicobacter pylori: What May Be the Relationship? J. Neurogastroenterol. Motil. 2010, 16, 243-250. [CrossRef]

229. Hong, S.J.; Kim, S.W. Helicobacter pylori Infection in Gastroesophageal Reflux Disease in the Asian Countries. Gastroenterol. Res. Pract. 2015, 2015, 985249.

230. Ye, W.; Held, M.; Lagergren, J.; Engstrand, L.; Blot, W.J.; McLaughlin, J.K.; Nyrén, O. Helicobacter pylori Infection and Gastric Atrophy: Risk of Adenocarcinoma and Squamous-Cell Carcinoma of the Esophagus and Adenocarcinoma of the Gastric Cardia. J. Natl. Cancer Inst. 2004, 96, 388-396. [CrossRef]

231. De Martel, C.; Llosa, A.E.; Farr, S.M.; Friedman, G.D.; Vogelman, J.H.; Orentreich, N.; Corley, D.A.; Parsonnet, J. Helicobacter pyloriInfection and the Risk of Development of Esophageal Adenocarcinoma. J. Infect. Dis. 2005, 191, 761-767. [CrossRef]

232. De Martel, C.; Haggerty, T.D.; Corley, A.U.; Vogelman, J.H.; Orentreich, N.; Parsonnet, J. Serum Ghrelin Levels and Risk of Subsequent Adenocarcinoma of the Esophagus. Am. J. Gastroenterol. 2007, 102, 1166-1172. [CrossRef]

233. Kandulski, A.; Malfertheiner, P. Helicobacter pylori and gastroesophageal reflux disease. Curr. Opin. Gastroenterol. 2014, 30, 402-407. [CrossRef]

234. Sugimoto, M.; Uotani, T.; Ichikawa, H.; Andoh, A.; Furuta, T. Gastroesophageal Reflux Disease in Time Covering Eradication for All Patients Infected with Helicobacter pylori in Japan. Digestion 2016, 93, $24-31$. [CrossRef] [PubMed]

235. Tomasello, G.; Giordano, F.; Mazzola, M.; Jurjus, R.; Jurjus, A.; Damiani, P.; Nobile, S.; Carini, F.; Leone, A. Helicobacter pylori and Barrett's esophagus: A protective factor or a real cause? J. Boil. Regul. Homeost. Agents 2017, 31, 9-15.

236. Sonnenberg, A.; Turner, K.O.; Spechler, S.J.; Genta, R.M. The influence of Helicobacter pylori on the ethnic distribution of Barrett's metaplasia. Aliment. Pharm. 2016, 45, 283-290. [CrossRef] [PubMed]

237. Eross, B.; Farkas, N.; Vincze, A.; Tinusz, B.; Szapary, L.; Garami, A.; Balasko, M.; Sarlos, P.; Czopf, L.; Alizadeh, H.; et al. Helicobacter pylori infection reduces the risk of Barrett's esophagus: A meta-analysis and systematic review. Helicobacter 2018, 23, e12504. [CrossRef] [PubMed]

238. Polyzos, S.A.; Zeglinas, C.; Artemaki, F.; Doulberis, M.; Kazakos, E.; Katsinelos, P.; Kountouras, J. Helicobacter pylori infection and esophageal adenocarcinoma: A review and a personal view. Ann. Gastroenterol. 2017, 31, 8-13. [CrossRef] 
239. Gao, H.; Li, L.; Zhang, C.; Tu, J.; Geng, X.; Wang, J.; Zhou, X.; Jing, J.; Pan, W.-S. Systematic Review with Meta-analysis: Association of Helicobacter pylori Infection with Esophageal Cancer. Gastroenterol. Res. Pract. 2019, 2019, 1953497. [CrossRef]

240. Rossi, G.; Gambi, R.; Uncini, R.; Piccinini, R.; Berardi, S.; Pengo, G.; Bassotti, G.; Cerquetella, M. Severe gastritis with double Helicobacter spp. infection associated with Barrett's esophagus in a cheetah. Helicobacter 2014, 19, 462-464. [CrossRef]

241. Graham, D.Y. Helicobacter pylori is not and never was "protective" against anything, including GERD. Dig. Dis. Sci. 2003, 48, 629-630. [CrossRef]

242. Kountouras, J.; Chatzopoulos, D.; Zavos, C. Eradication of Helicobacter pylori might halt the progress to oesophageal adenocarcinoma in patients with gastro-oesophageal reflux disease and Barrett's oesophagus. Med. Hypotheses 2007, 68, 1174-1175. [CrossRef]

243. Schwizer, W.; Thumshirn, M.; Dent, J.; Guldenschuh, I.; Menne, D.; Cathomas, G.; Fried, M. Helicobacter pylori and symptomatic relapse of gastro-oesophageal reflux disease: A randomised controlled trial. Lancet 2001, 357, 1738-1742. [CrossRef]

244. Moayyedi, P.; Soo, S.; Deeks, J.J.; Delaney, B.C.; Harris, A.; Innes, M.; Oakes, R.; Wilson, S.; Roalfe, A.; Bennett, C.; et al. Withdrawn: Eradication of Helicobacter pylori for non-ulcer dyspepsia. Cochrane Database Syst. Rev. 2011, 2001, CD002096.

245. Kountouras, J.; Zavos, C.; Chatzopoulos, D.; Romiopoulos, I.; Polyzos, S.A.; Kapetanakis, N.; Tsiaousi, E.; Vardaka, E.; Deretzi, G.; Tsarouchas, G.; et al. Letter: Is Helicobacter pylori behind Barrett's oesophagus and colorectal neoplasms? Aliment. Pharm. 2013, 37, 837. [CrossRef]

246. Kountouras, J.; Zavos, C.; Polyzos, S.A.; Katsinelos, P. Helicobacter pylori infection and gastroesophageal reflux disease-Barrett's esophagus sequence "dilemma". Ann. Gastroenterol. 2015, 28, 153.

247. Doulberis, M.; Kountouras, J.; Polyzos, S.A.; Tzivras, D.; Vardaka, E.; Kountouras, C.; Tzilves, D.; Kotronis, G.; Boutsikou, E.; Gialamprinou, D.; et al. Impact of Helicobacter pylori and/or Helicobacter pylori-related metabolic syndrome on gastroesophageal reflux disease-Barrett's esophagus- esophageal adenocarcinoma sequence. Helicobacter 2018, 23, e12534. [CrossRef]

248. Schwizer, W.; Menne, D.; Schütze, K.; Vieth, M.; Goergens, R.; Malfertheiner, P.; Leodolter, A.; Fried, M.; Fox, M.R. The effect of Helicobacter pylori infection and eradication in patients with gastro-oesophageal reflux disease: A parallel-group, double-blind, placebo-controlled multicentre study. United Eur. Gastroenterol. J. 2013, 1, 226-235. [CrossRef]

249. Aghayeva, S.; Mara, K.C.; Katzka, D.A. The impact of Helicobacter pylori on the presence of Barrett's esophagus in Azerbaijan, a high-prevalence area of infection. Dis. Esophagus 2019, 32. [CrossRef]

250. Doorakkers, E.; Lagergren, J.; Santoni, G.; Engstrand, L.; Brusselaers, N. Helicobacter pylori eradication treatment and the risk of Barrett's esophagus and esophageal adenocarcinoma. Helicobacter 2020, 25, e12688. [CrossRef]

251. Xie, F.-J. Helicobacter pyloriinfection and esophageal cancer risk: An updated meta-analysis. World J. Gastroenterol. 2013, 19, 6098-6107. [CrossRef]

252. Yaghoobi, M.; Farrokhyar, F.; Yuan, Y.; Hunt, R.H. Is There an Increased Risk of GERD After Helicobacter pylori Eradication?: A Meta-Analysis. Am. J. Gastroenterol. 2010, 105, 1007-1013. [CrossRef]

253. Saad, A.M.; Choudhary, A.; Bechtold, M.L. Effect of Helicobacter pyloritreatment on gastroesophageal reflux disease (GERD): Meta-analysis of randomized controlled trials. Scand. J. Gastroenterol. 2012, 47, 129-135. [CrossRef] [PubMed]

254. Qian, B.; Ma, S.; Shang, L.; Qian, J.; Zhang, G. Effects of Helicobacter pylori Eradication on Gastroesophageal Reflux Disease. Helicobacter 2011, 16, 255-265. [CrossRef] [PubMed]

255. Kumar, S.; Metz, D.C.; Ginsberg, G.G.; Kaplan, D.E.; Goldberg, D.S. Oesophageal and proximal gastric adenocarcinomas are rare after detection of Helicobacter pylori infection. Aliment. Pharm. 2020, 51, 781-788. [CrossRef] [PubMed]

256. Miyakoshi, N.; Kasukawa, Y.; Sasaki, H.; Kamo, K.; Shimada, Y. Impact of spinal kyphosis on gastroesophageal reflux disease symptoms in patients with osteoporosis. Osteoporos. Int. 2008, 20, 1193-1198. [CrossRef]

257. Yamane, Y.; Yamaguchi, T.; Tsumori, M.; Yamauchi, M.; Yano, S.; Yamamoto, M.; Honda, C.; Kinoshita, Y.; Sugimoto, T. Elcatonin is effective for lower back pain and the symptoms of gastroesophageal reflux disease in elderly osteoporotic patients with kyphosis. Geriatr. Gerontol. Int. 2011, 11, 215-220. [CrossRef] 
258. Sugimoto, M.; Hasegawa, T.; Nishino, M.; Sahara, S.; Uotani, T.; Ichikawa, H.; Kagami, T.; Sugimoto, K.; Yamato, Y.; Togawa, D.; et al. Improvement of gastroesophageal reflux disease in Japanese patients with spinal kyphotic deformity who underwent surgical spinal correction. Dig. Endosc. 2015, 28, 50-58. [CrossRef] [PubMed]

259. Kumar, S.; Drake, M.T.; Schleck, C.D.; Johnson, M.L.; Alexander, J.A.; Katzka, D.A.; Iyer, P.G. Incidence and predictors of osteoporotic fractures in patients with Barrett's oesophagus: A population-based nested case-control study. Aliment. Pharm. 2017, 46, 1094-1102. [CrossRef]

260. Malfertheiner, P.; Mégraud, F.; O’Morain, A.C.; Atherton, J.; Axon, A.T.R.; Bazzoli, F.; Gensini, G.F.; Gisbert, J.P.; Graham, D.Y.; Rokkas, T.; et al. Management of Helicobacter pyloriinfection-The Maastricht IV/Florence Consensus Report. Gut 2012, 61, 646-664. [CrossRef]

261. Zagari, R.M.; Romano, M.; Ojetti, V.; Stockbrugger, R.; Gullini, S.; Annibale, B.; Farinati, F.; Ierardi, E.; Maconi, G.; Rugge, M.; et al. Guidelines for the management of Helicobacter pylori infection in Italy: The III Working Group Consensus Report 2015. Dig. Liver Dis. 2015, 47, 903-912. [CrossRef]

262. Pytlik, M.; Cegiela, U.; Nowinska, B.; Folwarczna, J.; Sliwinski, L.; Kaczmarczyk-Sedlak, I.; Pytlik, M.; Bolek, D.; Korzeniowska, H. Bone remodeling after administration of proton pump (H+/K+-ATPase) inhibitors and alendronate in ovariectomized rats. Acta Pol. Pharm. 2012, 69, 113-120.

263. Hasanin, A.H. Impact of omeprazole on bone remodeling in normal and ovariectomized Wistar rats. Eur. Rev. Med. Pharm. Sci. 2014, 18, 1948-1956.

264. Matuszewska, A.; Nowak, B.; Rzeszutko, M.; Zduniak, K.; Szandruk, M.; Jêdrzejuk, D.; Landwójtowicz, M.; Bolanowski, M.; Pieśniewska, M.; Kwiatkowska, J.; et al. Effects of long-term administration of pantoprazole on bone mineral density in young male rats. Pharm. Rep. 2016, 68, 1060-1064. [CrossRef]

265. Yang, Y.-X.; Lewis, J.D.; Epstein, S.; Metz, D.C. Long-term Proton Pump Inhibitor Therapy and Risk of Hip Fracture. JAMA 2006, 296, 2947-2953. [CrossRef] [PubMed]

266. Fournier, M.R.; Targownik, E.L.; Leslie, W.D. Proton pump inhibitors, osteoporosis, and osteoporosis-related fractures. Maturitas 2009, 64, 9-13. [CrossRef] [PubMed]

267. Corley, D.A.; Kubo, A.; Zhao, W.; Quesenberry, C. Proton Pump Inhibitors and Histamine-2 Receptor Antagonists Are Associated with Hip Fractures Among At-Risk Patients. Gastroenterology 2010, 139, $93-101$. [CrossRef] [PubMed]

268. Kwok, C.S.; Yeong, J.K.; Loke, Y.K. Meta-analysis: Risk of fractures with acid-suppressing medication. Bone 2011, 48, 768-776. [CrossRef] [PubMed]

269. Eom, C.-S.; Park, S.M.; Myung, S.-K.; Yun, J.M.; Ahn, J.-S. Use of Acid-Suppressive Drugs and Risk of Fracture: A Meta-analysis of Observational Studies. Ann. Fam. Med. 2011, 9, 257-267. [CrossRef]

270. Ngamruengphong, S.; Leontiadis, G.I.; Radhi, S.; Dentino, A.; Nugent, K. Proton Pump Inhibitors and Risk of Fracture: A Systematic Review and Meta-Analysis of Observational Studies. Am. J. Gastroenterol. 2011, 106, 1209-1218. [CrossRef]

271. Ye, X.; Liu, H.; Wu, C.; Qin, Y.; Zang, J.; Gao, Q.; Zhang, X.; He, J. Proton pump inhibitors therapy and risk of hip fracture. Eur. J. Gastroenterol. Hepatol. 2011, 23, 794-800. [CrossRef]

272. Lau, Y.T.; Ahmed, N.N. Fracture Risk and Bone Mineral Density Reduction Associated with Proton Pump Inhibitors. Pharm. J. Hum. Pharm. Drug Ther. 2012, 32, 67-79. [CrossRef]

273. Khalili, H.; Huang, E.S.; Jacobson, B.C.; Camargo, A.C.; Feskanich, D.; Chan, A.T. Use of proton pump inhibitors and risk of hip fracture in relation to dietary and lifestyle factors: A prospective cohort study. BMJ 2012, 344, e372. [CrossRef] [PubMed]

274. Fraser, L.-A.; Leslie, W.D.; Targownik, L.E.; Papaioannou, A.; Adachi, J.D.; CaMos Research Group. The effect of proton pump inhibitors on fracture risk: Report from the Canadian Multicenter Osteoporosis Study. Osteoporos. Int. 2012, 24, 1161-1168.

275. Lee, J.-Y.; Youn, K.; Choi, N.-K.; Lee, J.-H.; Kang, D.; Song, H.J.; Park, B.-J. A population-based case-control study: Proton pump inhibition and risk of hip fracture by use of bisphosphonate. J. Gastroenterol. 2013, 48, 1016-1022. [CrossRef] [PubMed]

276. Cea-Soriano, L.; Ruigómez, A.; Johansson, S.; Rodríguez, L.A.G. Study of the Association Between Hip Fracture and Acid-Suppressive Drug Use in a UK Primary Care Setting. Pharm. J. Hum. Pharm. Drug Ther. 2014, 34, 570-581. [CrossRef]

277. Ding, J.; Heller, D.A.; Ahern, F.M.; Brown, T.V. The Relationship Between Proton Pump Inhibitor Adherence and Fracture Risk in the Elderly. Calcif. Tissue Int. 2014, 94, 597-607. [CrossRef] [PubMed] 
278. Adams, A.L.; Black, M.H.; Zhang, J.L.; Shi, J.M.; Jacobsen, S.J. Proton-pump inhibitor use and hip fractures in men: A population-based case-control study. Ann. Epidemiol. 2014, 24, 286-290. [CrossRef]

279. Cai, D.; Feng, W.; Jiang, Q. Acid-suppressive medications and risk of fracture: An updated meta-analysis. Int. J. Clin. Exp. Med. 2015, 8, 8893-8904.

280. Freedberg, D.E.; Kim, L.S.; Yang, Y.-X. The Risks and Benefits of Long-term Use of Proton Pump Inhibitors: Expert Review and Best Practice Advice from the American Gastroenterological Association. Gastroenterology 2017, 152, 706-715. [CrossRef]

281. Van Der Hoorn, M.M.; Tett, S.E.; De Vries, O.J.; Dobson, A.J.; Peeters, G. The effect of dose and type of proton pump inhibitor use on risk of fractures and osteoporosis treatment in older Australian women: A prospective cohort study. Bone 2015, 81, 675-682. [CrossRef]

282. Zhou, B.; Huang, Y.; Li, H.; Sun, W.; Liu, J. Proton pump inhibitors and fracture risk: Response to comments. Osteoporos. Int. 2015, 27, 1673-1674. [CrossRef]

283. Mössner, J. The Indications, Applications, and Risks of Proton Pump Inhibitors. Dtsch. Aerzteblatt Online 2016, 113, 477-483. [CrossRef]

284. Andersen, B.N.; Johansen, P.B.; Abrahamsen, B. Proton pump inhibitors and osteoporosis. Curr. Opin. Rheumatol. 2016, 28, 420-425. [CrossRef]

285. Maes, M.L.; Fixen, D.R.; Linnebur, S.A. Adverse effects of proton-pump inhibitor use in older adults: A review of the evidence. Adv. Drug Saf. 2017, 8, 273-297. [CrossRef]

286. Wang, L.; Li, M.; Cao, Y.; Han, Z.; Wang, X.; Atkinson, E.J.; Liua, H.; Amin, S. Proton Pump Inhibitors and the Risk for Fracture at Specific Sites: Data Mining of the FDA Adverse Event Reporting System. Sci. Rep. 2017, 7, 5527. [CrossRef]

287. Dubcenco, E.; Beers-Block, P.; Kim, L.; Schotland, P.; Levine, J.; McCloskey, C.; Bashaw, E.D. A Proton Pump Inhibitor in the Reformulation Setting: Bioequivalence and Potential Implications for Long-Term Safety. Clin. Transl. Sci. 2017, 10, 387-394. [CrossRef]

288. Nehra, A.K.; Alexander, J.A.; Loftus, C.G.; Nehra, V. Proton Pump Inhibitors: Review of Emerging Concerns. Mayo Clin. Proc. 2018, 93, 240-246. [CrossRef] [PubMed]

289. Liu, J.; Li, X.; Fan, L.; Yang, J.; Wang, J.; Sun, J.; Wang, Z. Proton pump inhibitors therapy and risk of bone diseases: An update meta-analysis. Life Sci. 2019, 218, 213-223. [CrossRef]

290. Park, J.-H.; Song, Y.; Jung, J.-H.; Han, K. Comparative analysis of the risk of osteoporotic fractures with proton pump inhibitor use and histamine-2 receptor antagonist therapy in elderly women: A nationwide population-based nested case-control study. Bone 2020, 135, 115306. [CrossRef]

291. Lewis, J.R.; Barre, D.; Zhu, K.; Ivey, K.L.; Lim, E.M.; Hughes, J.; Prince, R.L. Long-Term Proton Pump Inhibitor Therapy and Falls and Fractures in Elderly Women: A Prospective Cohort Study. J. Bone Miner. Res. 2014, 29, 2489-2497. [CrossRef]

292. Thaler, H.; Sterke, C.; Van Der Cammen, T.J.M. Association of proton pump inhibitor use with recurrent falls and risk of fractures in older women: A study of medication use in older fallers. J. Nutr. Health Aging 2016, 20, 77-81. [CrossRef]

293. Lai, S.-W. Proton pump inhibitors use and risk of falls. QJM: Int. J. Med. 2018, 112, 317. [CrossRef]

294. Yu, E.W.; Blackwell, T.; Ensrud, K.E.; Hillier, T.A.; Lane, N.E.; Orwoll, E.; Bauer, D.C. Acid-Suppressive Medications and Risk of Bone Loss and Fracture in Older Adults. Calcif. Tissue Int. 2008, 83, 251-259. [CrossRef] [PubMed]

295. Laine, L. Proton pump inhibitors and bone fractures? Am. J. Gastroenterol. 2009, 104 (Suppl. 2), S21-S26.

296. Gray, S.L.; Lacroix, A.Z.; Larson, J.; Robbins, J.; Cauley, J.A.; Manson, J.E.; Chen, Z. Proton Pump Inhibitor Use, Hip Fracture, and Change in Bone Mineral Density in Postmenopausal Women. Arch. Intern. Med. 2010, 170, 765. [CrossRef]

297. Pouwels, S.; Lalmohamed, A.; Souverein, P.C.; Cooper, C.; Veldt, B.J.; Leufkens, H.G.; De Boer, A.; Van Staa, T.P.; De Vries, F. Use of proton pump inhibitors and risk of hip/femur fracture: A population-based case-control study. Osteoporos. Int. 2010, 22, 903-910. [CrossRef]

298. Targownik, E.L.; Leslie, W.D. The relationship among proton pump inhibitors, bone disease and fracture. Expert Opin. Drug Saf. 2011, 10, 901-912. [CrossRef] 
299. Targownik, E.L.; Leslie, W.D.; Davison, K.S.; Goltzman, D.; Jamal, S.A.; Kreiger, N.; Josse, R.G.; Kaiser, S.M.; Kovacs, C.S.; Prior, J.C.; et al. The Relationship Between Proton Pump Inhibitor Use and Longitudinal Change in Bone Mineral Density: A Population-Based from the Canadian Multicentre Osteoporosis Study (CaMos). Am. J. Gastroenterol. 2012, 107, 1361-1369. [CrossRef]

300. Reyes, C.; Formiga, F.; Coderch, M.; Hoyo, J.; Ferriz, G.; Casanovas, J.; Monteserín, R.; Brotons, C.; Rojas, M.; Moral, I. Use of proton pump inhibitors and risk of fragility hip fracture in a Mediterranean region. Bone 2013, 52, 557-561. [CrossRef] [PubMed]

301. Solomon, D.H.; Diem, S.J.; Ruppert, K.; Lian, Y.J.; Liu, C.-C.; Wohlfart, A.; Greendale, G.A.; Finkelstein, J.S. Bone Mineral Density Changes Among Women Initiating Proton Pump Inhibitors or H2 Receptor Antagonists: A SWAN Cohort Study. J. Bone Miner. Res. 2015, 30, 232-239. [CrossRef]

302. Vaezi, M.F.; Yang, Y.-X.; Howden, C.W. Complications of Proton Pump Inhibitor Therapy. Gastroenterology 2017, 153, 35-48. [CrossRef]

303. Harding, B.N.; Weiss, N.S.; Walker, R.L.; Larson, E.B.; Dublin, S. Proton pump inhibitor use and the risk of fractures among an older adult cohort. Pharm. Drug Saf. 2018, 27, 596-603. [CrossRef]

304. Singh, A.; Cresci, G.A.; Kirby, D.F. Proton Pump Inhibitors: Risks and Rewards and Emerging Consequences to the Gut Microbiome. Nutr. Clin. Pract. 2018, 33, 614-624. [CrossRef] [PubMed]

305. Torvinen-Kiiskinen, S.; Tolppanen, A.-M.; Koponen, M.; Tanskanen, A.; Tiihonen, J.; Hartikainen, S.; Taipale, H. Proton pump inhibitor use and risk of hip fractures among community-dwelling persons with Alzheimer's disease-a nested case-control study. Aliment. Pharm. 2018, 47, 1135-1142. [CrossRef] [PubMed]

306. Xavier, S.; Magalhães, J.; Cotter, J. Proton Pump Inhibitors: Are They a Real Threat to the Patient? Ge Port. J. Gastroenterol. 2018, 25, 243-252. [CrossRef] [PubMed]

307. Lai, S.-W. Proton Pump Inhibitors and Fracture Risk. Am. J. Gastroenterol. 2019, 114, 1693. [CrossRef]

308. Ozen, G.; Pedro, S.; Wolfe, F.; Michaud, K. Medications associated with fracture risk in patients with rheumatoid arthritis. Ann. Rheum. Dis. 2019, 78, 1041-1047. [CrossRef]

309. Hoff, M.; Skovlund, E.; Skurtveit, S.; Meyer, H.; Langhammer, A.; Søgaard, A.; Syversen, U.; Forsmo, S.; Abrahamsen, B.; Schei, B. Proton pump inhibitors and fracture risk. The HUNT study, Norway. Osteoporos. Int. 2019, 31, 109-118. [CrossRef]

310. Fedida, B.; Schermann, H.; Ankory, R.; Rotman, D.; Shichman, I.; Yoffe, V.; Shlaifer, A.; Luger, E. Fracture risk of young adults receiving proton-pump inhibitors and $\mathrm{H} 2$-receptor antagonists. Int. J. Clin. Pract. 2019, 73, e13339. [CrossRef]

311. Sugiyama, T. Understanding the Current Evidence on Proton Pump Inhibitor Use and Bone Health. Gastroenterology 2019, 157, 585. [CrossRef]

312. Sugiyama, T. Response to Lai "Proton Pump Inhibitors and Fracture Risk". Am. J. Gastroenterol. 2019, 114, 1693-1694. [CrossRef]

313. Nassar, Y.; Richter, S. Proton-pump Inhibitor Use and Fracture Risk: An Updated Systematic Review and Meta-analysis. J. Bone Metab. 2018, 25, 141-151. [CrossRef]

314. Poly, T.; Islam, M.; Yang, H.-C.; Wu, C.; Li, Y.-C. (Jack) Proton pump inhibitors and risk of hip fracture: A meta-analysis of observational studies. Osteoporos. Int. 2018, 30, 103-114. [CrossRef] [PubMed]

315. Vinke, P.; Wesselink, E.; Van Orten-Luiten, A.C.B.; Van Norren, K. The Use of Proton Pump Inhibitors May Increase Symptoms of Muscle Function Loss in Patients with Chronic Illnesses. Int. J. Mol. Sci. 2020, 21, 323. [CrossRef] [PubMed]

316. Kinjo, M.; Setoguchi, S.; Solomon, D.H. Antihistamine Therapy and Bone Mineral Density: Analysis in a Population-Based US Sample. Am. J. Med. 2008, 121, 1085-1091. [CrossRef] [PubMed]

317. Cosman, F.; De Beur, S.J.; LeBoff, M.S.; Lewiecki, E.M.; Tanner, B.; Randall, S.; Lindsay, R. Clinician's Guide to Prevention and Treatment of Osteoporosis. Osteoporos. Int. 2014, 25, 2359-2381. [CrossRef] [PubMed]

318. Camacho, P.M.; Petak, S.M.; Binkley, N.; Diab, D.L.; Eldeiry, L.S.; Farooki, A.; Harris, S.T.; Hurley, D.L.; Kelly, J.; Lewiecki, E.M.; et al. American Association of Clinical Endocrinologists/American College of Endocrinology Clinical Practice Guidelines for the Diagnosis and Treatment of Postmenopausal Osteoporosis-2020 Update Executive Summary. Endocr. Pract. 2020. [CrossRef]

319. Hansen, K.E.; Nieves, J.W.; Nudurupati, S.V.; Metz, D.C.; Perez, M.C. Dexlansoprazole and Esomeprazole Do Not Affect Bone Homeostasis in Healthy Postmenopausal Women. Gastroenterology 2018, 156, 926-934.e6. [CrossRef] 
320. Moayyedi, P.; Eikelboom, J.W.; Bosch, J.; Connolly, S.J.; Dyal, L.; Shestakovska, O.; Leong, D.; Anand, S.S.; Störk, S.; Branch, K.R.; et al. Pantoprazole to Prevent Gastroduodenal Events in Patients Receiving Rivaroxaban and/or Aspirin in a Randomized, Double-Blind, Placebo-Controlled Trial. Gastroenterology 2019, 157, 403-412.e5. [CrossRef]

321. Rodríguez, L.A.G.; Lagergren, J.; Lindblad, M. Gastric acid suppression and risk of oesophageal and gastric adenocarcinoma: A nested case control study in the UK. Gut 2006, 55, 1538-1544. [CrossRef]

322. Tamim, H.; Duranceau, A.; Chen, L.-Q.; LeLorier, J. Association between use of acid-suppressive drugs and risk of gastric cancer. A nested case-control study. Drug Saf. 2008, 31, 675-684. [CrossRef]

323. Suissa, S.; Suissa, A. Proton-pump inhibitors and increased gastric cancer risk: Time-related biases. Gut 2018, 67, 2228-2229. [CrossRef]

324. Ahn, J.S.; Eom, C.-S.; Jeon, C.Y.; Park, S.M. Acid suppressive drugs and gastric cancer: A meta-analysis of observational studies. World J. Gastroenterol. 2013, 19, 2560-2568. [CrossRef]

325. Cheung, K.S.; Chan, E.W.; Wong, A.Y.S.; Chen, L.; Wong, I.C.K.; Leung, W.K. Long-term proton pump inhibitors and risk of gastric cancer development after treatment for Helicobacter pylori: A population-based study. Gut 2017, 67, 28-35. [CrossRef] [PubMed]

326. Peng, Y.-C.; Huang, L.-R.; Lin, C.-L.; Hsu, W.-Y.; Chang, C.-S.; Yeh, H.-Z.; Kao, C.-H. Association between proton pump inhibitors use and risk of gastric cancer in patients with GERD. Gut 2018, 68, 374-376. [CrossRef] [PubMed]

327. Lai, S.-W.; Lai, H.-C.; Lin, C.-L.; Liao, K.-F. Proton pump inhibitors and risk of gastric cancer in a case-control study. Gut 2018, 68, 765-767. [CrossRef] [PubMed]

328. Wan, Q.-Y.; Wu, X.-T.; Li, N.; Du, L.; Wu, X. Long-term proton pump inhibitors use and risk of gastric cancer: A meta-analysis of 926386 participants. Gut 2018, 68, 762-764. [CrossRef] [PubMed]

329. Tran-Duy, A.; Spaetgens, B.; Hoes, A.W.; De Wit, N.J.; Stehouwer, C.D. Use of Proton Pump Inhibitors and Risks of Fundic Gland Polyps and Gastric Cancer: Systematic Review and Meta-analysis. Clin. Gastroenterol. Hepatol. 2016, 14, 1706-1719.e5. [CrossRef]

330. Joo, M.K.; Park, J.-J.; Chun, H.J. Proton pump inhibitor: The dual role in gastric cancer. World J. Gastroenterol. 2019, 25, 2058-2070. [CrossRef]

331. Papamichael, K.X.; Papaioannou, G.; Karga, H.; Roussos, A.; Mantzaris, G.J. Helicobacter pylori infection and endocrine disorders: Is there a link? World J. Gastroenterol. 2009, 15, 2701-2707. [CrossRef]

332. Pellicano, R.; Franceschi, F.; Saracco, G.; Fagoonee, S.; Roccarina, D.; Gasbarrini, A. Helicobacters and Extragastric Diseases. Helicobacter 2009, 14, 58-68. [CrossRef]

333. Tan, H.J.; Goh, K.-L. Extragastrointestinal manifestations of Helicobacter pylori infection: Facts or myth? A critical review. J. Dig. Dis. 2012, 13, 342-349. [CrossRef]

334. Banić, M.; Franceschi, F.; Babic, Z.; Gasbarrini, A. Extragastric Manifestations of Helicobacter pylori Infection. Helicobacter 2012, 17, 49-55. [CrossRef] [PubMed]

335. Franceschi, F.; Gasbarrini, A.; Polyzos, S.A.; Kountouras, J. Extragastric Diseases andHelicobacter pylori. Helicobacter 2015, 20 (Suppl. 1), 40-46. [CrossRef]

336. Sotuneh, N.; Hosseini, S.R.; Shokri-Shirvani, J.; Bijani, A.; Ghadimi, R. Helicobacter Pylori Infection and Metabolic Parameters: Is There an Association in Elderly Population? Int. J. Prev. Med. 2014, 5, 1537-1542.

337. Wong, F.; Rayner-Hartley, E.; Byrne, M.F. Extraintestinal manifestations of Helicobacter pylori: A concise review. World J. Gastroenterol. 2014, 20, 11950-11961. [CrossRef]

338. Hagymási, K.; Tulassay, Z. Helicobacter pyloriinfection: New pathogenetic and clinical aspects. World J. Gastroenterol. 2014, 20, 6386-6399. [CrossRef] [PubMed]

339. Campuzano-Maya, G. Hematologic manifestations of Helicobacter pyloriinfection. World J. Gastroenterol. 2014, 20, 12818-12838. [CrossRef]

340. Goni, E.; Franceschi, F. Helicobacter pyloriand extragastric diseases. Helicobacter 2016, 21 (Suppl. 1), $45-48$. [CrossRef]

341. Jiang, J.; Chen, Y.; Shi, J.; Song, C.; Zhang, J.; Wang, K.-J. Population attributable burden of Helicobacter pylori-related gastric cancer, coronary heart disease, and ischemic stroke in China. Eur. J. Clin. Microbiol. Infect. Dis. 2016, 36, 199-212. [CrossRef] [PubMed]

342. Bravo, D.; Hoare, A.; Soto, C.; Valenzuela, M.A.; Quest, A.F.G. Helicobacter pylori in human health and disease: Mechanisms for local gastric and systemic effects. World J. Gastroenterol. 2018, 24, 3071-3089. [CrossRef] [PubMed] 
343. Razuka-Ebela, D.; Giupponi, B.; Franceschi, F. Helicobacter pylori and extragastric diseases. Helicobacter 2018, 23 (Suppl. 1), e12520. [CrossRef]

344. Tsay, F.-W.; Hsu, P.-I.H. pylori infection and extra-gastroduodenal diseases. J. Biomed. Sci. 2018, $25,65$. [CrossRef] [PubMed]

345. Franceschi, F.; Covino, M.; Baudron, C.R. Review: Helicobacter pylori and extragastric diseases. Helicobacter 2019, 24 (Suppl. 1), e12636. [CrossRef] [PubMed]

346. Baudron, C.R.; Franceschi, F.; Salles, N.; Gasbarrini, A. Extragastric Diseases andHelicobacter pylori. Helicobacter 2013, 18 (Suppl. 1), 44-51. [CrossRef]

347. Dennison, E.M.; Compston, J.E.; Flahive, J.; Siris, E.S.; Gehlbach, S.H.; Adachi, J.D.; Boonen, S.; Chapurlat, R.; Díez-Pérez, A.; Anderson, F.A.; et al. Effect of co-morbidities on fracture risk: Findings from the Global Longitudinal Study of Osteoporosis in Women (GLOW). Bone 2012, 50, 1288-1293. [CrossRef] [PubMed]

348. Bloch, F.; Thibaud, M.; Tournoux-Facon, C.; Brèque, C.; Rigaud, A.-S.; Dugué, B.; Kemoun, G. Estimation of the risk factors for falls in the elderly: Can meta-analysis provide a valid answer? Geriatr. Gerontol. Int. 2012, 13, 250-263. [CrossRef]

349. Zendehdel, A.; Roham, M. Role of Helicobacter pylori infection in the manifestation of old age-related diseases. Mol. Genet. Genom. Med. 2020, 8, e1157. [CrossRef]

350. Vranken, L.; Wyers, C.E.; Van Der Velde, R.Y.; Janzing, H.M.; Kaarsemaker, S.; Geusens, P.P.; Bergh, J.P.V.D. Comorbidities and medication use in patients with a recent clinical fracture at the Fracture Liaison Service. Osteoporos. Int. 2017, 29, 397-407. [CrossRef]

351. Walker-Bone, K. Recognizing and treating secondary osteoporosis. Nat. Rev. Rheumatol. 2012, 8, 480-492. [CrossRef]

352. Bogoch, E.R.; Elliot-Gibson, V.; Wang, R.Y.C.; Josse, R.G. Secondary Causes of Osteoporosis in Fracture Patients. J. Orthop. Trauma 2012, 26, e145-e152. [CrossRef]

353. Diab, D.L.; Watts, N.B. Secondary Osteoporosis. Clin. Obs. Gynecol. 2013, 56, 686-693. [CrossRef]

354. 3Bours, S.P.; Bergh, J.P.V.D.; Van Geel, T.; Geusens, P.P. Secondary osteoporosis and metabolic bone disease in patients 50 years and older with osteoporosis or with a recent clinical fracture. Curr. Opin. Rheumatol. 2014, 26, 430-439.

355. Mirza, F.S.; Canalis, E. MANAGEMENT OF ENDOCRINE DISEASE: Secondary osteoporosis: Pathophysiology and management. Eur. J. Endocrinol. 2015, 173, R131-R151. [CrossRef] [PubMed]

356. Roux, C.; Briot, K. Osteoporosis in 2017: Addressing the crisis in the treatment of osteoporosis. Nat. Rev. Rheumatol. 2018, 14, 67-68. [CrossRef] [PubMed]

357. Pouresmaeili, F.; Goh, Y.M.; Kamarehei, M.; Meng, G.Y. A comprehensive overview on osteoporosis and its risk factors. Clin. Risk Manag. 2018, 14, 2029-2049. [CrossRef] [PubMed]

358. Kanis, J.A.; Cooper, C.; Rizzoli, R.; Reginster, J.Y.; Scientific Advisory Board of the European Society for Clinical and Economic Aspects of Osteoporosis and Osteoarthritis; Committee of Scientific Advisors of the International Osteoporosis Foundation. European guidance for the diagnosis and management of osteoporosis in postmenopausal women. Osteoporos. Int. 2019, 30, 3-44. [CrossRef]

359. Kanis, J.A.; Harvey, N.C.; McCloskey, E.; Bruyere, O.; Veronese, N.; Lorentzon, M.; Cooper, C.; Rizzoli, R.; Adib, G.; Al-Daghri, N.; et al. Algorithm for the management of patients at low, high and very high risk of osteoporotic fractures. Osteoporos. Int. 2020, 31, 1-12. [CrossRef]

360. Malfertheiner, P.; Mégraud, F.; O’Morain, A.C.; Gisbert, J.P.; Kuipers, E.; Axon, A.; Bazzoli, F.; Gasbarrini, A.; Atherton, J.; Graham, D.Y.; et al. Management of Helicobacter pyloriinfection-The Maastricht V/Florence Consensus Report. Gut 2016, 66, 6-30. [CrossRef]

361. Smyk, D.S. Helicobacter pyloriand autoimmune disease: Cause or bystander. World J. Gastroenterol. 2014, 20, 613-629. [CrossRef]

362. Polyzos, S.A.; Kountouras, J.; Papatheodorou, A.; Patsiaoura, K.; Katsiki, E.; Zafeiriadou, E.; Zavos, C.; Anastasiadou, K.; Terpos, E. Helicobacter pylori infection in patients with nonalcoholic fatty liver disease. Metabolism 2013, 62, 121-126. [CrossRef]

363. Sumida, Y.; Kanemasa, K.; Imai, S.; Mori, K.; Tanaka, S.; Shimokobe, H.; Kitamura, Y.; Fukumoto, K.; Kakutani, A.; Ohno, T.; et al. Helicobacter pylori infection might have a potential role in hepatocyte ballooning in nonalcoholic fatty liver disease. J. Gastroenterol. 2015, 50, 996-1004. [CrossRef] 
364. Upala, S.; Jaruvongvanich, V.; Riangwiwat, T.; Jaruvongvanich, S.; Sanguankeo, A. Association betweenHelicobacter pyloriinfection and metabolic syndrome: A systematic review and meta-analysis. J. Dig. Dis. 2016, 17, 433-440. [CrossRef] [PubMed]

365. Kim, T.J.; Sinn, D.H.; Min, Y.W.; Son, H.J.; Chang, Y.; Baek, S.-Y.; Ahn, S.H.; Lee, H.; Ryu, S. A cohort study on Helicobacter pylori infection associated with nonalcoholic fatty liver disease. J. Gastroenterol. 2017, 29, 559-1210. [CrossRef] [PubMed]

366. Tang, D.M.; Kumar, S. The Association Between Helicobacter pylori Infection and Nonalcoholic Fatty Liver Disease. Curr. Gastroenterol. Rep. 2017, 19, 5. [CrossRef] [PubMed]

367. Wijarnpreecha, K.; Thongprayoon, C.; Panjawatanan, P.; Manatsathit, W.; Jaruvongvanich, V.; Ungprasert, P. Helicobacter pylori and Risk of Nonalcoholic Fatty Liver Disease. J. Clin. Gastroenterol. 2018, 52, 386-391. [CrossRef]

368. Yu, Y.; Cai, J.; Song, Z.; Wang, J.; Wu, L. Association of Helicobacter pylori infection with metabolic syndrome in aged Chinese females. Exp. Med. 2019, 17, 4403-4408. [CrossRef]

369. Yu, Y.-Y.; Cai, J.-T.; Song, Z.-Y.; Tong, Y.-L.; Wang, J.-H. The associations among Helicobacter pylori infection, white blood cell count and nonalcoholic fatty liver disease in a large Chinese population. Medicine 2018, 97, e13271. [CrossRef]

370. Jiang, T.; Chen, X.; Xia, C.; Liu, H.; Yan, H.; Wang, G.; Wu, Z. Association between Helicobacter pylori infection and non-alcoholic fatty liver disease in North Chinese: A cross-sectional study. Sci. Rep. 2019, 9, 4874. [CrossRef]

371. Mantovani, A.; Turino, T.; Altomari, A.; Lonardo, A.; Zoppini, G.; Valenti, L.; Tilg, H.; Byrne, C.D.; Targher, G. Association between Helicobacter pylori infection and risk of nonalcoholic fatty liver disease: An updated meta-analysis. Metabolism 2019, 96, 56-65. [CrossRef]

372. Zhou, B.; Yang, H.; Xu, W.; Wang, K.; Guo, P.; Ai, Y. Association between Helicobacter pylori infection and nonalcoholic fatty liver disease: A systematic review and meta-analysis of observational studies. Helicobacter 2019, 24, e12576. [CrossRef]

373. Polyzos, S.A.; Kountouras, J.; Zavos, C.; Deretzi, G. Helicobacter pylori Infection and insulin resistance. Helicobacter 2012, 18, 165-166. [CrossRef]

374. He, C.; Yang, Z.; Lu, N.-H. Helicobacter pyloriinfection and diabetes: Is it a myth or fact. World J. Gastroenterol. 2014, 20, 4607-4617. [CrossRef]

375. Bonfigli, A.R.; Boemi, M.; Festa, R.; Bonazzi, P.; Brandoni, G.; Spazzafumo, L.; Olivieri, F.; Ceriello, A.; Genovese, S.; Testa, R. Randomized, double-blind, placebo-controlled trial to evaluate the effect of Helicobacter pylori eradication on glucose homeostasis in type 2 diabetic patients. Nutr. Metab. Cardiovasc. Dis. 2016, 26, 893-898. [CrossRef] [PubMed]

376. Chen, Y.-Y.; Fang, W.-H.; Wang, C.-C.; Kao, T.-W.; Chang, Y.-W.; Wu, C.-J.; Zhou, Y.-C.; Sun, Y.-S.; Chen, W.-L. Helicobacter pylori infection increases risk of incident metabolic syndrome and diabetes: A cohort study. PLoS ONE 2019, 14, e0208913. [CrossRef] [PubMed]

377. Nodoushan, S.A.H.; Nabavi, A. The Interaction of Helicobacter pylori Infection and Type 2 Diabetes Mellitus. Adv. Biomed. Res. 2019, 8, 15. [CrossRef]

378. Wang, F.; Fu, Y.; Lv, Z. Association of Helicobacter pyloriinfection with diabetic complications: A meta-analysis. Endocr. Res. 2013, 39, 7-12. [CrossRef] [PubMed]

379. Zhou, F.; Zhong, X.; Chen, J.; Li, C.; Shang, M.; Jiang, C.; Yang, H.; Zhao, W.; Liu, L. Helicobacter pylori infection associated with type 2 diabetic nephropathy in patients with dyspeptic symptoms. Diabetes Res. Clin. Pr. 2015, 110, 328-334. [CrossRef] [PubMed]

380. Demir, M.; Gokturk, H.S.; Ozturk, N.A.; Kulaksizoglu, M.; Serin, E.; Yilmaz, U. Helicobacter pylori Prevalence in Diabetes Mellitus Patients with Dyspeptic Symptoms and its Relationship to Glycemic Control and Late Complications. Dig. Dis. Sci. 2008, 53, 2646-2649. [CrossRef] [PubMed]

381. Zhang, Y.; Du, T.; Chen, X.; Yu, X.; Tu, L.; Zhang, C. Association between Helicobacter pylori infection and overweight or obesity in a Chinese population. J. Infect. Dev. Ctries. 2015, 9, 945-953. [CrossRef] [PubMed]

382. Xu, X.; Li, W.; Qin, L.; Yang, W.; Yu, G.; Wei, Q. Relationship between Helicobacter pylori infection and obesity in Chinese adults: A systematic review with meta-analysis. PLoS ONE 2019, 14, e0221076. [CrossRef]

383. Xia, H.H.; Talley, N.J.; Kam, E.P.; Young, L.J.; Hammer, J.; Horowitz, M. Helicobacter pylori infection is not associated with diabetes mellitus, nor with upper gastrointestinal symptoms in diabetes mellitus. Am. J. Gastroenterol. 2001, 96, 1039-1046. [CrossRef] 
384. Stanciu, O.G.; Trifan, A.; Sfarti, C.; Cojocariu, C.; Stanciu, C. Helicobacter pylori infection in patients with diabetes mellitus. Rev. Med. Chir. Soc. Med. Nat. Iasi 2003, 107, 59-65. [PubMed]

385. Dai, Y.-N.; Yu, W.-L.; Zhu, H.-T.; Ding, J.-X.; Yu, C.-H.; Li, Y.-M. Is Helicobacter pyloriinfection associated with glycemic control in diabetics? World J. Gastroenterol. 2015, 21, 5407-5416. [CrossRef] [PubMed]

386. Okushin, K.; Takahashi, Y.; Yamamichi, N.; Shimamoto, T.; Enooku, K.; Fujinaga, H.; Tsutsumi, T.; Shintani, Y.; Sakaguchi, Y.; Ono, S.; et al. Helicobacter pylori infection is not associated with fatty liver disease including non-alcoholic fatty liver disease: A large-scale cross-sectional study in Japan. Bmc Gastroenterol. 2015, 15, 25. [CrossRef] [PubMed]

387. Baeg, M.K.; Yoon, S.K.; Ko, S.-H.; Noh, Y.-S.; Lee, I.-S.; Choi, M.-G. Helicobacter pyloriinfection is not associated with nonalcoholic fatty liver disease. World J. Gastroenterol. 2016, 22, 2592-2600. [CrossRef]

388. Xu, M.-Y.; Liu, L.; Yuan, B.-S.; Yin, J.; Lu, Q. Association of obesity withHelicobacter pyloriinfection: A retrospective study. World J. Gastroenterol. 2017, 23, 2750-2756. [CrossRef]

389. Mohammadifard, M.; Saremi, Z.; Rastgoo, M.; Akbari, E. Relevance between Helicobacter pylori Infection and Non-Alcoholic Fatty Liver Disease in Birjand, Iran. J. Med. Life 2019, 12, 168-172.

390. Lender, N.; Talley, N.J.; Enck, P.; Haag, S.; Zipfel, S.; Morrison, M.; Holtmann, G.J. Review article: Associations betweenHelicobacter pyloriand obesity - an ecological study. Aliment. Pharm. 2014, 40, 24-31. [CrossRef]

391. Vo, H.D.; Goli, S.; Gill, R.; Anderson, V.; Stefanov, D.G.; Xu, J.; Kulsum-Mecci, N.; Schwarz, S.M.; Rabinowitz, S.S. Inverse Correlation Between Helicobacter pylori Colonization and Obesity in a Cohort of Inner City Children. Helicobacter 2014, 20, 64-68. [CrossRef]

392. Moran-Lev, H.; Lubetzky, R.; Mandel, D.; Yerushalmy-Feler, A.; Cohen, S. Inverse Correlation between Helicobacter pylori Colonization and Pediatric Overweight: A Preliminary Study. Child. Obes. 2017, 13, 267-271. [CrossRef]

393. Moyaert, H.; Franceschi, F.; Roccarina, D.; Ducatelle, R.; Haesebrouck, F.; Gasbarrini, A. Extragastric Manifestations of Helicobacter pyloriInfection: OtherHelicobacters. Helicobacter 2008, 13, 47-57. [CrossRef]

394. Pellicano, R.; Oliaro, E.; Fagoonee, S.; Astegiano, M.; Berrutti, M.; Saracco, G.; Smedile, A.; Repici, A.; Leone, N.; Castelli, A.; et al. Clinical and biochemical parameters related to cardiovascular disease after Helicobacter pylori eradication. Int. Angiol. 2009, 28, 469-473. [PubMed]

395. Figura, N.; Franceschi, F.; Santucci, A.; Bernardini, G.; Gasbarrini, G.; Gasbarrini, A. Extragastric Manifestations of Helicobacter pylori Infection. Helicobacter 2010, 15 (Suppl. 1), 60-68. [CrossRef]

396. Christodoulou, D.K.; Milionis, H.J.; Pappa, P.; Katsanos, K.H.; Sigounas, D.; Florentin, M.; Elisaf, M.S.; Tsianos, E.V. Association of Helicobacter pylori infection with cardiovascular disease-Is it just a myth? Eur. J. Intern. Med. 2011, 22, 191-194. [CrossRef] [PubMed]

397. Rogha, M.; Dadkhah, D.; Pourmoghaddas, Z.; Shirneshan, K.; Nikvarz, M.; Pourmoghaddas, M. Association of helicobacter pylori infection with severity of coronary heart disease. Arya Atheroscler. 2012, 7, 138-141. [PubMed]

398. Matusiak, A.; Chałubiński, M.; Broncel, M.; Rechcinski, T.; Rudnicka, K.; Miszczyk, E.; Walencka, M.; Strapagiel, D.; Gajewski, A.; Chmiela, M. Putative consequences of exposure to Helicobacter pylori infection in patients with coronary heart disease in terms of humoral immune response and inflammation. Arch. Med. Sci. 2016, 12, 45-54. [CrossRef] [PubMed]

399. Wang, J.-W.; Tseng, K.-L.; Hsu, C.-N.; Liang, C.-M.; Tai, W.-C.; Ku, M.-K.; Hung, T.-H.; Yuan, L.-T.; Nguang, S.-H.; Yang, S.-C.; et al. Association between Helicobacter pylori eradication and the risk of coronary heart diseases. PLoS ONE 2018, 13, e0190219. [CrossRef] [PubMed]

400. Jamkhande, P.G.; Gattani, S.G.; Farhat, S.A. Helicobacter pylori and cardiovascular complications: A mechanism based review on role of Helicobacter pylori in cardiovascular diseases. Integr. Med. Res. 2016, 5, 244-249. [CrossRef]

401. Cauley, J.A.; Chalhoub, D.; Kassem, A.M.; Fuleihan, G.E.-H. Geographic and ethnic disparities in osteoporotic fractures. Nat. Rev. Endocrinol. 2014, 10, 338-351. [CrossRef]

402. Johnell, O.; Kanis, J. An estimate of the worldwide prevalence and disability associated with osteoporotic fractures. Osteoporos. Int. 2006, 17, 1726-1733. [CrossRef]

403. Hagino, H.; Sakamoto, K.; Harada, A.; Nakamura, T.; Mutoh, Y.; Mori, S.; Endo, N.; Nakano, T.; Itoi, E.; Kita, K.; et al. Nationwide one-decade survey of hip fractures in Japan. J. Orthop. Sci. 2010, 15, 737-745. [CrossRef] 
404. Court-Brown, C.; Clement, N.; Duckworth, A.; Biant, L.; McQueen, M. The changing epidemiology of fall-related fractures in adults. Injury 2017, 48, 819-824. [CrossRef] [PubMed]

405. Aspray, T.; Hill, T.R. Osteoporosis and the Ageing Skeleton. Subcell. Biochem. 2019, 91, 453-476. [PubMed]

406. Weidauer, L.; Binkley, T.; Beare, T.; Minett, M.; McCormack, L.; Wey, A.; Specker, B. Do Sex Differences Exist in Rates of Falls and Fractures in Hutterite, Rural, and Nonrural Populations, Aged 20 to 66 Years? Clin. Orthop. Relat. Res. 2015, 473, 2514-2520. [CrossRef] [PubMed]

407. Ibrahim, A.; Singh, D.K.A.; Shahar, S. 'Timed Up and Go' test: Age, gender and cognitive impairment stratified normative values of older adults. PLOS ONE 2017, 12, e0185641. [CrossRef] [PubMed]

408. Rankinen, T.; Sarzynski, M.A.; Ghosh, S.; Bouchard, C. Are there genetic paths common to obesity, cardiovascular disease outcomes, and cardiovascular risk factors? Circ. Res. 2015, 116, 909-922. [CrossRef] [PubMed]

409. Greenbaum, J.; Deng, H.-W. A Statistical Approach to Fine Mapping for the Identification of Potential Causal Variants Related to Bone Mineral Density. J. Bone Miner. Res. 2017, 32, 1651-1658. [CrossRef] [PubMed]

410. Greenbaum, J.; Wu, K.; Zhang, L.; Shen, H.; Zhang, J.; Deng, H.-W. Increased detection of genetic loci associated with risk predictors of osteoporotic fracture using a pleiotropic cFDR method. Bone 2017, 99, 62-68. [CrossRef]

411. Wang, C.; Wang, J.; Luo, Y. Systemic tracking of diagnostic function modules for post-menopausal osteoporosis in a differential co-expression network view. Exp. Med. 2018, 15, 2961-2967. [CrossRef]

412. Lin, X.; Peng, C.; Greenbaum, J.; Li, Z.-F.; Wu, K.-H.; Ao, Z.-X.; Zhang, T.; Shen, J.; Deng, H.-W. Identifying potentially common genes between dyslipidemia and osteoporosis using novel analytical approaches. Mol. Genet. Genom. 2018, 293, 711-723. [CrossRef]

413. Trajanoska, K.; Rivadeneira, F. Using Mendelian Randomization to Decipher Mechanisms of Bone Disease. Curr. Osteoporos. Rep. 2018, 16, 531-540. [CrossRef]

414. Zheng, J.; Frysz, M.; Kemp, J.P.; Evans, D.M.; Smith, G.D.; Tobias, J.H. Use of Mendelian Randomization to Examine Causal Inference in Osteoporosis. Front. Endocrinol. 2019, 10, 807. [CrossRef]

415. Hu, Y.; Tan, L.-J.; Chen, X.-D.; Greenbaum, J.; Deng, H.-W. Identification of novel variants associated with osteoporosis, type 2 diabetes and potentially pleiotropic loci using pleiotropic cFDR method. Bone 2018, 117, 6-14. [CrossRef] [PubMed]

416. Jia, X.; Yang, Y.; Chen, Y.; Xia, Z.; Zhang, W.; Feng, Y.; Li, Y.; Tan, J.; Xu, C.; Zhang, Q.; et al. Multivariate analysis of genome-wide data to identify potential pleiotropic genes for type 2 diabetes, obesity and coronary artery disease using MetaCCA. Int. J. Cardiol. 2019, 283, 144-150. [CrossRef] [PubMed]

417. Cherny, S.S.; Freidin, M.B.; Williams, F.M.K.; Livshits, G. The analysis of causal relationships between blood lipid levels and BMD. PLoS ONE 2019, 14, e0212464. [CrossRef] [PubMed]

418. Yang, T.-L.; Shen, H.; Liu, A.; Dong, S.-S.; Zhang, L.; Deng, F.-Y.; Zhao, Q.; Deng, H.-W. A road map for understanding molecular and genetic determinants of osteoporosis. Nat. Rev. Endocrinol. 2019, 16, 91-103. [CrossRef]

419. Gu, H.; Huang, Z.; Chen, G.; Zhou, K.; Zhang, Y.; Chen, J.; Xu, J.; Yin, X. Network and pathway-based analyses of genes associated with osteoporosis. Medcine 2020, 99, e19120. [CrossRef] [PubMed]

420. Carbone, L.D.; Bůžková, P.; Fink, H.A.; Lee, J.S.; Chen, Z.; Ahmed, A.; Parashar, S.; Robbins, J.R. Hip fractures and heart failure: Findings from the Cardiovascular Health Study. Eur. Heart J. 2009, 31, 77-84. [CrossRef]

421. Szulc, P. Association between cardiovascular diseases and osteoporosis-Reappraisal. Bonekey Rep. 2012, 1, 144. [CrossRef]

422. Fisher, A.; Srikusalanukul, W.; Davis, M.; Smith, P. Cardiovascular diseases in older patients with osteoporotic hip fracture: Prevalence, disturbances in mineral and bone metabolism, and bidirectional links. Clin. Interv. Aging 2013, 8, 239-256. [CrossRef]

423. Chen, S.-J.; Lin, C.-S.; Lin, C.-L.; Kao, C.-H. Osteoporosis Is Associated with High Risk for Coronary Heart Disease. Medcine 2015, 94, e1146. [CrossRef]

424. Popp, A.; Meer, S.; Krieg, M.-A.; Perrelet, R.; Hans, D.; Lippuner, K. Bone mineral density (BMD) and vertebral trabecular bone score (TBS) for the identification of elderly women at high risk for fracture: The SEMOF cohort study. Eur. Spine J. 2015, 25, 3432-3438. [CrossRef] [PubMed]

425. Zhang, Y.; Feng, B. Systematic review and meta-analysis for the association of bone mineral density and osteoporosis/osteopenia with vascular calcification in women. Int. J. Rheum. Dis. 2016, 20, 154-160. [CrossRef] [PubMed] 
426. Center, J.R. Fracture Burden: What Two and a Half Decades of Dubbo Osteoporosis Epidemiology Study Data Reveal About Clinical Outcomes of Osteoporosis. Curr. Osteoporos. Rep. 2017, 20, 783-795. [CrossRef] [PubMed]

427. Lian, X.-L.; Zhang, Y.-P.; Li, X.; Jing, L.-D.; Cairang, Z.-M.; Gou, J.-Q. Exploration on the relationship between the elderly osteoporosis and cardiovascular disease risk factors. Eur. Rev. Med. Pharm. Sci. 2017, 21, 4386-4390.

428. Veronese, N.; Stubbs, B.; Crepaldi, G.; Solmi, M.; Cooper, C.; Harvey, N.C.; Reginster, J.-Y.; Rizzoli, R.; Civitelli, R.; Schofield, P.; et al. Relationship Between Low Bone Mineral Density and Fractures With Incident Cardiovascular Disease: A Systematic Review and Meta-Analysis. J. Bone Miner. Res. 2017, 32, 1126-1135. [CrossRef]

429. Chuang, T.-L.; Lin, J.-W.; Wang, Y.-F. Bone Mineral Density as a Predictor of Atherogenic Indexes of Cardiovascular Disease, Especially in Nonobese Adults. Dis. Markers 2019, 2019, 1045098. [CrossRef]

430. Verheyen, N.; Grübler, M.R.; Catena, C.; Fahrleitner-Pammer, A.; Van Ballegooijen, A.J. The Bone-Cardiovascular Axis: Mechanisms and Clinical Relevance. Int. J. Endocrinol. 2018, 2018, 9689106. [CrossRef]

431. Arnold, I.C.; Dehzad, N.; Reuter, S.; Martin, H.; Becher, B.; Taube, C.; Müller, A. Helicobacter pylori infection prevents allergic asthma in mouse models through the induction of regulatory T cells. J. Clin. Investig. 2011, 121, 3088-3093. [CrossRef]

432. Engler, D.B.; Reuter, S.; Van Wijck, Y.; Urban, S.; Kyburz, A.; Maxeiner, J.; Martin, H.; Yogev, N.; Waisman, A.; Gerhard, M.; et al. Effective treatment of allergic airway inflammation with Helicobacter pylori immunomodulators requires BATF3-dependent dendritic cells and IL-10. Proc. Natl. Acad. Sci. USA 2014, 111, 11810-11815. [CrossRef]

433. Castano-Rodriguez, N.; Kaakoush, N.O.; Lee, W.S.; Mitchell, H.M. Dual role of Helicobacter and Campylobacter species in IBD: A systematic review and meta-analysis. Gut 2017, 66, 235-249. [CrossRef]

434. Lebwohl, B.; Blaser, M.J.; Ludvigsson, J.F.; Green, P.H.R.; Rundle, A.; Sonnenberg, A.; Genta, R.M. Decreased risk of celiac disease in patients with Helicobacter pylori colonization. Am. J. Epidemiol. 2013, 178, 1721-1730. [CrossRef] [PubMed]

435. Robinson, K. Helicobacter pylori-Mediated Protection against Extra-Gastric Immune and Inflammatory Disorders: The Evidence and Controversies. Diseases 2015, 3, 34-55. [CrossRef] [PubMed]

436. Sonnenberg, A.; Dellon, E.S.; Turner, K.O.; Genta, R.M. The influence of Helicobacter pylori on the ethnic distribution of esophageal eosinophilia. Helicobacter 2016, 22, e12370. [CrossRef]

437. Lucero, Y.; Oyarzun, A.; O’Ryan, M.; Quera, R.; Espinosa, N.; Valenzuela, R.; Simian, D.; Alcalde, E.; Arce, C.; Farfan, M.J.; et al. Helicobacter pylori cagA+ Is Associated with Milder Duodenal Histological Changes in Chilean Celiac Patients. Front. Cell Infect. Microbiol. 2017, 7, 376. [CrossRef] [PubMed]

438. Narang, M.; Puri, A.S.; Sachdeva, S.; Singh, J.; Kumar, A.; Saran, R.K. Celiac disease and Helicobacter pylori infection in children: Is there any Association? J. Gastroenterol. Hepatol. 2017, 32, 1178-1182. [CrossRef]

439. Shah, S.C.; Tepler, A.; Peek, R.M.; Colombel, J.-F.; Hirano, I.; Narula, N. Association Between Helicobacter pylori Exposure and Decreased Odds of Eosinophilic Esophagitis-A Systematic Review and Meta-analysis. Clin. Gastroenterol. Hepatol. 2019, 17, 2185-2198.e3. [CrossRef]

440. Tepler, A.; Narula, N.; Peek, R.M.; Patel, A.; Edelson, C.; Colombel, J.-F.; Shah, S.C. Systematic review with meta-analysis: Association between Helicobacter pylori CagA seropositivity and odds of inflammatory bowel disease. Aliment. Pharm. 2019, 50, 121-131. [CrossRef]

441. Ness-Jensen, E.; Langhammer, A.; Hveem, K.; Lu, Y. Helicobacter pylori in relation to asthma and allergy modified by abdominal obesity: The HUNT study in Norway. World Allergy Organ. J. 2019, 12, 100035. [CrossRef]

442. Shimoyama, T.; Higuchi, H.; Matsuzaka, M.; Chinda, D.; Nakaji, S.; Fukuda, S. Helicobacter pylori infection is associated with a decreased risk of tooth loss in healthy Japanese men. Jpn. J. Infect. Dis. 2013, 66, 489-492. [CrossRef]

443. Wang, Y.-C.; Lin, T.-Y.; Shang, S.-T.; Chen, H.-J.; Kao, C.-H.; Wu, C.-C.; Yang, T.-Y. Helicobacter pylori infection increases the risk of adult-onset asthma: A nationwide cohort study. Eur. J. Clin. Microbiol. Infect. Dis. 2017, 36, 1587-1594. [CrossRef] 
444. Wu, M.-C.; Huang, J.-Y.; Chen, H.-H.; Wei, J.C.-C. Effect of early eradication therapy on systemic lupus erythematosus risk in patients with Helicobacter pylori infection: A nationwide population-based cohort study. Lupus 2020, 29, 751-760. [CrossRef] [PubMed]

445. Chen, Q.; Zhou, X.; Tan, W.; Zhang, M. Association between Helicobacter pylori infection and Sjögren syndrome. Medcine 2018, 97, e13528. [CrossRef] [PubMed]

446. Choi, Y.M.; Kim, T.-Y.; Kim, E.Y.; Jang, E.K.; Jeon, M.J.; Kim, W.B.; Shong, Y.K. Association between thyroid autoimmunity and Helicobacter pylori infection. Korean J. Intern. Med. 2017, 32, 309-313. [CrossRef] [PubMed]

447. Gavalas, E.; Kountouras, J.; Boziki, M.; Zavos, C.; Polyzos, S.A.; Vlachaki, E.; Venizelos, I.; Tsiptsios, D.; Deretzi, G. Relationship between Helicobacter pylori infection and multiple sclerosis. Ann. Gastroenterol. 2015, 28, 353-356. [PubMed]

448. Deretzi, G.; Gavalas, E.; Boziki, M.; Tsiptsios, D.; Polyzos, S.A.; Venizelos, I.; Zavos, C.; Koutlas, E.; Tsiptsios, I.; Katsinelos, P.; et al. Impact of Helicobacter pylorion multiple sclerosis-related clinically isolated syndrome. Acta Neurol. Scand. 2015, 133, 268-275. [CrossRef]

449. den Hollander, W.J.; Broer, L.; Schurmann, C.; Meyre, D.; Hoed, C.M.D.; Mayerle, J.; Hofman, A.; Homuth, G.; Uitterlinden, A.G.; Lerch, M.M.; et al. Helicobacter pylori colonization and obesity-A Mendelian randomization study. Sci. Rep. 2017, 7, 14467. [CrossRef]

450. Chen, L.-W.; Kuo, S.-F.; Chen, C.-H.; Chien, C.-H.; Lin, C.-L.; Chien, R.-N. A community-based study on the association between Helicobacter pylori Infection and obesity. Sci. Rep. 2018, 8, 10746. [CrossRef] [PubMed]

451. Grundstrom, A.C.; Guse, C.E.; Layde, P.M. Risk factors for falls and fall-related injuries in adults 85 years of age and older. Arch. Gerontol. Geriatr. 2012, 54, 421-428. [CrossRef]

452. Boelens, C.; Hekman, E.E.; Verkerke, G.J. Risk factors for falls of older citizens. Technol. Health Care 2013, 21, 521-533. [CrossRef]

453. Angelousi, A.; Girerd, N.; Benetos, A.; Frimat, L.; Gautier, S.; Weryha, G.; Boivin, J.-M. Association between orthostatic hypotension and cardiovascular risk, cerebrovascular risk, cognitive decline and falls as well as overall mortality. J. Hypertens. 2014, 32, 1562-1571. [CrossRef]

454. Alamgir, H.; Wong, N.J.; Hu, Y.; Yu, M.; Marshall, A.; Yu, S. Epidemiology of Falls in Older Adults in Texas. South. Med. J. 2015, 108, 119-124. [CrossRef] [PubMed]

455. Ricci, F.; Fedorowski, A.; Radico, F.; Romanello, M.; Tatasciore, A.; Di Nicola, M.; Zimarino, M.; De Caterina, R. Cardiovascular morbidity and mortality related to orthostatic hypotension: A meta-analysis of prospective observational studies. Eur. Heart J. 2015, 36, 1609-1617. [CrossRef] [PubMed]

456. Hartog, L.C.; Schrijnders, D.; Landman, G.; Groenier, K.; Kleefstra, N.; Bilo, H.J.; Van Hateren, K.J.J. Is orthostatic hypotension related to falling? A meta-analysis of individual patient data of prospective observational studies. Age Ageing 2017, 46, 568-575. [CrossRef] [PubMed]

457. Paliwal, Y.; Slattum, P.W.; Ratliff, S.M. Chronic Health Conditions as a Risk Factor for Falls among the Community-Dwelling US Older Adults: A Zero-Inflated Regression Modeling Approach. Biomed. Res. Int. 2017, 2017, 5146378. [CrossRef] [PubMed]

458. Harvey, N.; Odén, A.; Orwoll, E.; Lapidus, J.; Kwok, T.; Karlsson, M.K.; Rosengren, B.E.; Ljunggren, Ö.; Cooper, C.; McCloskey, E.; et al. Falls Predict Fractures Independently of FRAX Probability: A Meta-Analysis of the Osteoporotic Fractures in Men (MrOS) Study. J. Bone Miner. Res. 2017, 33, 510-516. [CrossRef] [PubMed]

459. Hopewell, S.; Adedire, O.; Copsey, B.J.; Boniface, G.J.; Sherrington, C.; Clemson, L.; Close, J.C.T.; Lamb, S.E. Multifactorial and multiple component interventions for preventing falls in older people living in the community. Cochrane Database Syst. Rev. 2018, 7, CD012221. [CrossRef]

460. Guirguis-Blake, J.M.; Michael, Y.; Perdue, L.A.; Coppola, E.L.; Beil, T.L.; Thompson, J.H. Interventions to Prevent Falls in Community-Dwelling Older Adults: A Systematic Review for the US Preventive Services Task Force; Agency for Healthcare Research and Quality: Rockville, MD, USA, 2018.

461. Ronthal, M. Gait Disorders and Falls in the Elderly. Med. Clin. N. Am. 2019, 103, 203-213. [CrossRef]

462. Mol, A.; Hoang, P.T.S.B.; Sharmin, S.; Reijnierse, E.M.; Van Wezel, R.J.; Meskers, C.G.; Maier, A.B. Orthostatic Hypotension and Falls in Older Adults: A Systematic Review and Meta-analysis. J. Am. Med. Dir. Assoc. 2019, 20, 589-597.e5. [CrossRef]

463. Perng, H.-J.; Chiu, Y.-L.; Chung, C.-H.; Kao, S.; Chien, W.-C. Fall and risk factors for veterans and non-veterans inpatients over the age of 65 years: 14 years of long-term data analysis. BMJ Open 2019, 9, e030650. [CrossRef] 
464. Ganz, D.A.; Latham, N.K. Prevention of Falls in Community-Dwelling Older Adults. N. Engl. J. Med. 2020, 382, 734-743. [CrossRef]

465. Patel, D.; Ackermann, R.J. Issues in Geriatric Care: Falls. FP Essent. 2018, 468, 18-25. [PubMed]

466. Peeters, G.; Van Schoor, N.M.; Lips, P. Fall risk: The clinical relevance of falls and how to integrate fall risk with fracture risk. Best Pract. Res. Clin. Rheumatol. 2009, 23, 797-804. [CrossRef] [PubMed]

467. Ambrose, A.F.; Cruz, L.; Paul, G. Falls and Fractures: A systematic approach to screening and prevention. Maturitas 2015, 82, 85-93. [CrossRef] [PubMed]

468. Franse, C.; Carmen, B.; Rietjens, J.A.; Burdorf, A.; Van Grieken, A.; Korfage, I.J.; Van Der Heide, A.; Raso, F.M.; Van Beeck, E.; Raat, H. A prospective study on the variation in falling and fall risk among community-dwelling older citizens in 12 European countries. BMJ Open 2017, 7, e015827. [CrossRef] [PubMed]

469. Thayer, S.; Stolshek, B.S.; Rey, G.G.; Seare, J.G. Impact of Osteoporosis on High-Cost Chronic Diseases. Value Health 2014, 17, 43-50. [CrossRef] [PubMed]

470. Mai, H.T.; Tran, T.S.; Ho-Le, T.P.; Center, J.R.; Eisman, J.A.; Nguyen, T. Two-Thirds of All Fractures Are Not Attributable to Osteoporosis and Advancing Age: Implications for Fracture Prevention. J. Clin. Endocrinol. Metab. 2019, 104, 3514-3520. [CrossRef] [PubMed]

471. Karasik, D.; Kiel, D.P. Evidence for pleiotropic factors in genetics of the musculoskeletal system. Bone 2010, 46, 1226-1237. [CrossRef]

472. Fisher, F.M.; Maratos-Flier, E. Understanding the Physiology of FGF21. Annu. Rev. Physiol. 2016, 78, $223-241$. [CrossRef]

473. Karstoft, K.; Pedersen, B.K. Skeletal muscle as a gene regulatory endocrine organ. Curr. Opin. Clin. Nutr. Metab. Care 2016, 19, 270-275. [CrossRef]

474. Lee, Y.-S.; Huynh, T.V.; Lee, S.-J. Paracrine and endocrine modes of myostatin action. J. Appl. Physiol. 2016, 120, 592-598. [CrossRef]

475. Powers, S.K.; Radak, Z.; Ji, L.L. Exercise-induced oxidative stress: Past, present and future. J. Physiol. 2016, 594, 5081-5092. [CrossRef] [PubMed]

476. Rodríguez, A.J.; Scott, D.; Hodge, A.; English, D.R.; Giles, G.G.; Ebeling, P.R. Associations between hip bone mineral density, aortic calcification and cardiac workload in community-dwelling older Australians. Osteoporos. Int. 2017, 28, 2239-2245. [CrossRef] [PubMed]

477. Booth, F.W.; Roberts, C.K.; Thyfault, J.P.; Ruegsegger, G.N.; Toedebusch, R.G. Role of Inactivity in Chronic Diseases: Evolutionary Insight and Pathophysiological Mechanisms. Physiol. Rev. 2017, 97, 1351-1402. [CrossRef]

478. Rikkonen, T.; Sirola, J.; Salovaara, K.; Tuppurainen, M.; Jurvelin, J.S.; Honkanen, R.; Kröger, H. Muscle Strength and Body Composition Are Clinical Indicators of Osteoporosis. Calcif. Tissue Int. 2012, 91, 131-138. [CrossRef] [PubMed]

479. Kawao, N.; Kaji, H. Interactions Between Muscle Tissues and Bone Metabolism. J. Cell. Biochem. 2015, 116, 687-695. [CrossRef]

480. Tagliaferri, C.; Wittrant, Y.; Davicco, M.-J.; Walrand, S.; Coxam, V. Muscle and bone, two interconnected tissues. Ageing Res. Rev. 2015, 21, 55-70. [CrossRef]

481. Curtis, E.; Litwic, A.; Cooper, C.; Dennison, E.M. Determinants of Muscle and Bone Aging. J. Cell. Physiol. 2015, 230, 2618-2625. [CrossRef]

482. Karsenty, G.; Olson, E.N. Bone and Muscle Endocrine Functions: Unexpected Paradigms of Inter-organ Communication. Cell 2016, 164, 1248-1256. [CrossRef]

483. Hirschfeld, H.P.; Kinsella, R.; Duque, G. Osteosarcopenia: Where bone, muscle, and fat collide. Osteoporos. Int. 2017, 28, 2781-2790. [CrossRef]

484. Zanker, J.; Duque, G. Osteoporosis in Older Persons: Old and New Players. J. Am. Geriatr. Soc. 2018, 67, 831-840. [CrossRef]

485. Yoo, J.-I.; Kim, H.; Ha, Y.-C.; Kwon, H.-B.; Koo, K.-H. Osteosarcopenia in Patients with Hip Fracture Is Related with High Mortality. J. Korean Med. Sci. 2018, 33, e27. [CrossRef] [PubMed]

486. Yoon, B.-H.; Lee, J.-K.; Choi, D.-S.; Han, S.-H. Prevalence and Associated Risk Factors of Sarcopenia in Female Patients with Osteoporotic Fracture. J. Bone Metab. 2018, 25, 59-62. [CrossRef] [PubMed]

487. Bonewald, L.F. Use it or lose it to age: A review of bone and muscle communication. Bone 2019, 120, $212-218$. [CrossRef] [PubMed] 
488. Locquet, M.; Beaudart, C.; Durieux, N.; Reginster, J.-Y.; Bruyère, O. Relationship between the changes over time of bone mass and muscle health in children and adults: A systematic review and meta-analysis. BMC Musculoskelet. Disord. 2019, 20, 413-429. [CrossRef]

489. Laurent, M.; Dedeyne, L.; Dupont, J.; Mellaerts, B.; Dejaeger, M.; Gielen, E. Age-related bone loss and sarcopenia in men. Maturitas 2019, 122, 51-56. [CrossRef]

490. Lombardi, G.; Ziemann, E.; Banfi, G. Physical Activity and Bone Health: What Is the Role of Immune System? A Narrative Review of the Third Way. Front. Endocrinol. 2019, 10, 60. [CrossRef]

491. Kirk, B.; Al Saedi, A.; Duque, G. Osteosarcopenia: A case of geroscience. Aging Med. 2019, 2, 147-156. [CrossRef]

492. Herrmann, M.; Engelke, K.; Ebert, R.; Müller-Deubert, S.; Rudert, M.; Ziouti, F.; Jundt, F.; Felsenberg, D.; Jakob, F. Interactions between Muscle and Bone-Where Physics Meets Biology. Biomolecules 2020, 10, 432. [CrossRef]

493. Willems, S.M.; Wright, D.; Day, I.N.M.; Trajanoska, K.; Joshi, P.K.; Morris, J.A.; Matteini, A.M.; Garton, F.C.; Grarup, N.; Oskolkov, N.; et al. Large-scale GWAS identifies multiple loci for hand grip strength providing biological insights into muscular fitness. Nat. Commun. 2017, 8, 16015. [CrossRef]

494. Medina-Gomez, C.; Kemp, J.P.; Dimou, N.L.; Kreiner, E.; Chesi, A.; Zemel, B.S.; Bønnelykke, K.; Boer, C.G.; Ahluwalia, S.; Bisgaard, H.; et al. Bivariate genome-wide association meta-analysis of pediatric musculoskeletal traits reveals pleiotropic effects at the SREBF1/TOM1L2 locus. Nat. Commun. 2017, 8, 121. [CrossRef]

495. Trajanoska, K.; Rivadeneira, F.; Kiel, D.P.; Karasik, D. Genetics of Bone and Muscle Interactions in Humans. Curr. Osteoporos. Rep. 2019, 17, 86-95. [CrossRef] [PubMed]

496. rajanoska, K.; Morris, J.A.; Oei, L.; Zheng, H.-F.; Evans, D.M.; Kiel, U.P.; Ohlsson, C.; Richards, J.B.; Rivadeneira, F. Assessment of the genetic and clinical determinants of fracture risk: Genome wide association and mendelian randomisation study. BMJ 2018, 362, k3225. [CrossRef] [PubMed]

497. Patel, S.; Tweed, K.; Chinappen, U. Fall-related risk factors and osteoporosis in older women referred to an open access bone densitometry service. Age Ageing 2005, 34, 67-71. [CrossRef] [PubMed]

498. Verschueren, S.; Gielen, E.; O’Neill, T.W.; Pye, S.R.; Adams, J.E.; Ward, K.A.; Wu, F.C.; Szulc, P.; Laurent, M.; Claessens, F.; et al. Sarcopenia and its relationship with bone mineral density in middle-aged and elderly European men. Osteoporos. Int. 2012, 24, 87-98. [CrossRef] [PubMed]

499. Laurent, M.; Dubois, V.; Claessens, F.; Verschueren, S.; Vanderschueren, D.; Gielen, E.; Jardí, F. Muscle-bone interactions: From experimental models to the clinic? A critical update. Mol. Cell. Endocrinol. 2016, 432, 14-36. [CrossRef]

500. Paintin, J.; Cooper, C.; Dennison, E. Osteosarcopenia. Br. J. Hosp. Med. 2018, 79, 253-258. [CrossRef] [PubMed]

501. Locquet, M.; Beaudart, C.; Bruyère, O.; Kanis, J.A.; Delandsheere, L.; Reginster, J.-Y. Bone health assessment in older people with or without muscle health impairment. Osteoporos. Int. 2018, 29, 1057-1067. [CrossRef]

502. Compston, J.E.; McClung, M.R.; Leslie, W.D. Osteoporosis. Lancet 2019, 393, 364-376. [CrossRef]

503. Yeung, S.S.; Reijnierse, E.M.; Pham, V.K.; Trappenburg, M.C.; Lim, W.K.; Meskers, C.G.; Maier, A.B. Sarcopenia and its association with falls and fractures in older adults: A systematic review and meta-analysis. J. Cachex Sarcopenia Muscle 2019, 10, 485-500. [CrossRef]

504. De Abreu, D.C.C.; Trevisan, D.C.; Reis, J.G.; Costa, G.D.C.D.; Gomes, M.M.; Matos, M.S. Body balance evaluation in osteoporotic elderly women. Arch. Osteoporos. 2009, 4, 25-29. [CrossRef]

505. Chen, H.-T.; Ma, J.-X.; Liu, A.; Cui, Y.; Ma, X. The association between sarcopenia and fracture in middle-aged and elderly people: A systematic review and meta-analysis of cohort studies. Injury 2020, 51, 804-811. [CrossRef] [PubMed]

506. Zhang, X.; Zhang, W.; Wang, C.; Tao, W.; Dou, Q.; Yang, Y. Sarcopenia as a predictor of hospitalization among older people: A systematic review and meta-analysis. BMC Geriatr. 2018, 18, 188. [CrossRef] [PubMed]

507. Zhang, X.; Huang, P.; Dou, Q.; Wang, C.; Zhang, W.; Yang, Y.; Wang, J.; Xie, X.; Zhou, J.; Zeng, Y. Falls among older adults with sarcopenia dwelling in nursing home or community: A meta-analysis. Clin. Nutr. 2020, 39, 33-39. [CrossRef] [PubMed] 
508. Scott, D.; Cumming, R.; Naganathan, V.; Blyth, F.; Le Couteur, D.G.; Handelsman, D.J.; Seibel, M.; Waite, L.M.; Hirani, V. Associations of sarcopenic obesity with the metabolic syndrome and insulin resistance over five years in older men: The Concord Health and Ageing in Men Project. Exp. Gerontol. 2018, 108, 99-105. [CrossRef] [PubMed]

509. Reuben, D.B.; Gazarian, P.; Alexander, N.; Araujo, K.; Baker, D.; Bean, J.F.; Boult, C.; Charpentier, P.; Duncan, P.; Latham, N.; et al. The Strategies to Reduce Injuries and Develop Confidence in Elders Intervention: Falls Risk Factor Assessment and Management, Patient Engagement, and Nurse Co-management. J. Am. Geriatr. Soc. 2017, 65, 2733-2739. [CrossRef]

510. Ek, S.; Rizzuto, D.; Fratiglioni, L.; Johnell, K.; Xu, W.; Welmer, A.-K. Risk Profiles for Injurious Falls in People Over 60: A Population-Based Cohort Study. J. Gerontol. Ser. A: Biol. Sci. Med. Sci. 2017, 73, 233-239. [CrossRef]

511. Ensrud, K.E.; Ewing, S.K.; Taylor, B.C.; Fink, H.A.; Stone, K.L.; Cauley, J.A.; Tracy, J.K.; Hochberg, M.C.; Rodondi, N.; Cawthon, P.M.; et al. Frailty and Risk of Falls, Fracture, and Mortality in Older Women: The Study of Osteoporotic Fractures. J. Gerontol. Ser. A: Biol. Sci. Med. Sci. 2007, 62, 744-751. [CrossRef]

512. De Vries, O.J.; Peeters, G.M.E.E.; Lips, P.; Deeg, D.J.H. Does frailty predict increased risk of falls and fractures? A prospective population-based study. Osteoporos. Int. 2013, 24, 2397-2403. [CrossRef]

513. Milte, R.; Crotty, M. Musculoskeletal health, frailty and functional decline. Best Pract. Res. Clin. Rheumatol. 2014, 28, 395-410. [CrossRef]

514. Kojima, G. Frailty as a Predictor of Future Falls Among Community-Dwelling Older People: A Systematic Review and Meta-Analysis. J. Am. Med. Dir. Assoc. 2015, 16, 1027-1033. [CrossRef]

515. Kojima, G. Frailty as a predictor of fractures among community-dwelling older people: A systematic review and meta-analysis. Bone 2016, 90, 116-122. [CrossRef]

516. Walters, S.; Chan, S.; Goh, L.; Ong, T.; Sahota, O. The Prevalence of Frailty in Patients Admitted to Hospital with Vertebral Fragility Fractures. Curr. Rheumatol. Rev. 2016, 12, 244-247. [CrossRef] [PubMed]

517. McGuigan, F.E.; Bartosch, P.; Åkesson, K. Musculoskeletal health and frailty. Best Pract. Res. Clin. Rheumatol. 2017, 31, 145-159. [CrossRef]

518. Kim, H.-J.; Park, S.; Park, S.-H.; Park, J.; Chang, B.-S.; Lee, C.-K.; Yeom, J.S. Prevalence of Frailty in Patients with Osteoporotic Vertebral Compression Fracture and Its Association with Numbers of Fractures. Yonsei Med. J. 2018, 59, 317-324. [CrossRef] [PubMed]

519. Ravindrarajah, R.; Hazra, N.C.; Charlton, J.; Jackson, S.H.D.; Dregan, A.; Gulliford, M.C. Incidence and mortality of fractures by frailty level over 80 years of age: Cohort study using UK electronic health records. BMJ Open 2018, 8, e018836. [CrossRef] [PubMed]

520. Lam, F.M.H.; Leung, J.C.; Kwok, T.C.Y. The Clinical Potential of Frailty Indicators on Identifying Recurrent Fallers in the Community: The Mr. Os and Ms. OS Cohort Study in Hong Kong. J. Am. Med. Dir. Assoc. 2019, 20, 1605-1610. [CrossRef] [PubMed]

521. Kinjo, M.; Setoguchi, S.; Schneeweiss, S.; Solomon, D.H. Bone mineral density in subjects using central nervous system-active medications. Am. J. Med. 2005, 118, 1414.e7-1414.e12. [CrossRef] [PubMed]

522. Gonyeau, M.J. Statins and Osteoporosis: A Clinical Review. Pharm. J. Hum. Pharm. Drug 2005, 25, $228-243$. [CrossRef]

523. Jadhav, S.B.; Jain, G.K. Statins and osteoporosis: New role for old drugs. J. Pharm. Pharm. 2006, 58, 3-18. [CrossRef]

524. Horiuchi, N.; Maeda, T. Statins and bone metabolism. Oral Dis. 2006, 12, 85-101. [CrossRef]

525. Walsh, J.S.; Newman, C.; Eastell, R. Heart drugs that affect bone. Trends Endocrinol. Metab. 2012, 23, $163-168$. [CrossRef]

526. Hill, K.D.; Wee, R. Psychotropic Drug-Induced Falls in Older People. Drugs Aging 2012, 29, 15-30. [CrossRef] [PubMed]

527. Aluoch, A.O.; Jessee, R.; Habal, H.; Garcia-Rosell, M.; Shah, R.; Reed, G.; Carbone, L.D. Heart Failure as a Risk Factor for Osteoporosis and Fractures. Curr. Osteoporos. Rep. 2012, 10, 258-269. [CrossRef] [PubMed]

528. Ilić, K.; Obradović, N.; Vujasinović-Stupar, N. The Relationship Among Hypertension, Antihypertensive Medications, and Osteoporosis: A Narrative Review. Calcif. Tissue Int. 2012, 92, 217-227. [CrossRef]

529. Ghosh, M.; Majumdar, S.R. Antihypertensive medications, bone mineral density, and fractures: A review of old cardiac drugs that provides new insights into osteoporosis. Endocrine 2014, 46, 397-405. [CrossRef] [PubMed] 
530. Chen, Y.; Zhu, L.L.; Zhou, Q. Effects of drug pharmacokinetic/pharmacodynamic properties, characteristics of medication use, and relevant pharmacological interventions on fall risk in elderly patients. Clin. Risk Manag. 2014, 10, 437-448.

531. Thorell, K.; Ranstad, K.; Midlöv, P.; Borgquist, L.A.; Halling, A. Is use of fall risk-increasing drugs in an elderly population associated with an increased risk of hip fracture, after adjustment for multimorbidity level: A cohort study. BMC Geriatr. 2014, 14, 131. [CrossRef] [PubMed]

532. Gilbert, M.P.; Pratley, R.E. The Impact of Diabetes and Diabetes Medications on Bone Health. Endocr. Rev. 2015, 36, 194-213. [CrossRef]

533. Lin, S.-I.; Chang, K.-C.; Lee, H.-C.; Yang, Y.-C.; Tsauo, J.-Y. Problems and fall risk determinants of quality of life in older adults with increased risk of falling. Geriatr. Gerontol. Int. 2014, 15, 579-587. [CrossRef]

534. Ćurković, M.; Dodig-Curković, K.; Erić, A.P.; Kralik, K.; Pivac, N. Psychotropic medications in older adults: A review. Psychiatr. Danub. 2016, 28, 13-24.

535. Vianna, A.G.D.; Sanches, C.; Barreto, F.C. Review article: Effects of type 2 diabetes therapies on bone metabolism. Diabetol. Metab. Syndr. 2017, 9, 75. [CrossRef] [PubMed]

536. Puttnam, R.; Davis, B.R.; Pressel, S.L.; Whelton, P.K.; Cushman, W.C.; Louis, G.T.; Margolis, K.L.; Oparil, S.; Williamson, J.; Ghosh, A.; et al. Association of 3 Different Antihypertensive Medications With Hip and Pelvic Fracture Risk in Older Adults. JAMA Intern. Med. 2017, 177, 67-76. [CrossRef] [PubMed]

537. Brandt, J.; Leong, C. Benzodiazepines and Z-Drugs: An Updated Review of Major Adverse Outcomes Reported on in Epidemiologic Research. Drugs RED 2017, 17, 493-507. [CrossRef] [PubMed]

538. Donnelly, K.; Bracchi, R.; Hewitt, J.; Routledge, P.A.; Carter, B. Benzodiazepines, Z-drugs and the risk of hip fracture: A systematic review and meta-analysis. PLoS ONE 2017, 12, e0174730. [CrossRef] [PubMed]

539. Leach, M.J.; Pratt, N.L.; Roughead, E.E. Risk of Hip Fracture in Older People Using Selective Serotonin Reuptake Inhibitors and Other Psychoactive Medicines Concurrently: A Matched Case-Control Study in Australia. Drugs Real World Outcomes 2017, 4, 87-96. [CrossRef]

540. Kunutsor, S.K.; Blom, A.W.; Whitehouse, M.R.; Kehoe, P.G.; Laukkanen, J.A. Renin-angiotensin system inhibitors and risk of fractures: A prospective cohort study and meta-analysis of published observational cohort studies. Eur. J. Epidemiol. 2017, 32, 947-959. [CrossRef] [PubMed]

541. Kwok, T.C.Y.; Leung, J.; Barrett-Connor, E. Osteoporotic Fractures in Men (MrOS) Research Group ARB users exhibit a lower fracture incidence than ACE inhibitor users among older hypertensive men. Age Ageing 2017, 46, 57-64.

542. Mabilleau, G.; Gobron, B.; Bouvard, B.; Chappard, D. Incretin-based therapy for the treatment of bone fragility in diabetes mellitus. Peptides 2018, 100, 108-113. [CrossRef]

543. Seppala, L.J.; Van De Glind, E.M.; Daams, J.G.; Ploegmakers, K.J.; De Vries, M.; Wermelink, A.M.; Van Der Velde, N.; Blain, H.; Bousquet, J.; Bucht, G.; et al. Fall-Risk-Increasing Drugs: A Systematic Review and Meta-analysis: III. Others. J. Am. Med. Dir. Assoc. 2018, 19, 372.e1-372.e8. [CrossRef]

544. Treves, N.; Perlman, A.; Geron, L.K.; Asaly, A.; Matok, I. Z-drugs and risk for falls and fractures in older adults-A systematic review and meta-analysis. Age Ageing 2017, 47, 201-208. [CrossRef]

545. Cortet, B.; Lucas, S.; Legroux-Gerot, I.; Penel, G.; Chauveau, C.; Paccou, J. Bone disorders associated with diabetes mellitus and its treatments. Jt. Bone Spine 2019, 86, 315-320. [CrossRef] [PubMed]

546. Vestergaard, P. Drugs Causing Bone Loss. Handb. Exp. Pharm. 2019. [CrossRef]

547. Wang, J.; Su, K.; Sang, W.; Li, L.; Ma, S. Thiazide Diuretics and the Incidence of Osteoporotic Fracture: A Systematic Review and Meta-Analysis of Cohort Studies. Front. Pharm. 2019, 10, 1364. [CrossRef] [PubMed]

548. Taipale, H.; Rysä, J.; Hukkanen, J.; Koponen, M.; Tanskanen, A.; Tiihonen, J.; Kröger, H.; Hartikainen, S.; Tolppanen, A.-M. Long-term thiazide use and risk of low-energy fractures among persons with Alzheimer's disease-Nested case-control study. Osteoporos. Int. 2019, 30, 1481-1489. [CrossRef] [PubMed]

549. Chou, R.; Hartung, D.; Turner, J.; Blazina, I.; Chan, B.; Levander, X.; McDonagh, M.; Selph, S.; Fu, R.; Pappas, M. Opioid Treatments for Chronic Pain; Agency for Healthcare Research and Quality: Rockville, MD, USA, 2020.

550. Oh, T.K.; Song, I.-A. Metformin therapy and hip fracture risk among patients with type II diabetes mellitus: A population-based cohort study. Bone 2020, 135, 115325. [CrossRef] [PubMed] 
551. Mortensen, S.J.; Mohamadi, A.; Wright, C.L.; Chan, J.J.; Weaver, M.J.; Von Keudell, A.; Nazarian, A. Medications as a Risk Factor for Fragility Hip Fractures: A Systematic Review and Meta-analysis. Calcif. Tissue Int. 2020, 107, 1-9. [CrossRef]

552. Barzilay, J.I.; Davis, B.R.; Pressel, S.L.; Ghosh, A.; Puttnam, R.; Margolis, K.L.; Whelton, P.K. The Impact of Antihypertensive Medications on Bone Mineral Density and Fracture Risk. Curr. Cardiol. Rep. 2017, $19,76$. [CrossRef]

553. Napoli, N.; Chandran, M.; Pierroz, D.D.; Abrahamsen, B.; Schwartz, A.V.; Ferrari, S.L.; On behalf of the IOF Bone and Diabetes Working Group. Mechanisms of diabetes mellitus-induced bone fragility. Nat. Rev. Endocrinol. 2016, 13, 208-219. [CrossRef]

554. Lai, S.-W.; Cheng, K.-C.; Lin, C.-L.; Lai, S.-W. Furosemide use and acute risk of hip fracture in older people: A nationwide case-control study in Taiwan. Geriatr. Gerontol. Int. 2017, 17, 2552-2558. [CrossRef]

555. Andersen, C.U.; Lassen, P.O.; Usman, H.Q.; Albertsen, N.; Nielsen, L.P.; Andersen, S. Prevalence of medication-related falls in 200 consecutive elderly patients with hip fractures: A cross-sectional study. BMC Geriatr. 2020, 20, 121. [CrossRef]

556. Elias, A.M.; Ogunwale, A.N.; Pepin, M.J.; Bailey, J.C.; Adams, A.D.; Colón-Emeric, C.S.; Vognsen, J.D.; Schmader, K.E.; Pavon, J. High Prevalence of Fall-Related Medication Use in Older Veterans at Risk for Falls. J. Am. Geriatr. Soc. 2019, 68, 438-439. [CrossRef] [PubMed]

557. Cumming, R.G. Epidemiology of medication-related falls and fractures in the elderly. Drugs Aging 1998, 12, 43-53. [CrossRef]

558. Leipzig, R.M.; Cumming, R.G.; Tinetti, M.E. Drugs and Falls in Older People: A Systematic Review and Meta-analysis: I. Psychotropic Drugs. J. Am. Geriatr. Soc. 1999, 47, 30-39. [CrossRef] [PubMed]

559. Leipzig, R.M.; Cumming, R.G.; Tinetti, M.E. Drugs and Falls in Older People: A Systematic Review and Meta-analysis: II. Cardiac and Analgesic Drugs. J. Am. Geriatr. Soc. 1999, 47, 40-50. [CrossRef] [PubMed]

560. Ensrud, K.E.; Blackwell, T.; Mangione, C.M.; Bowman, P.J.; Bauer, D.C.; Schwartz, A.; Hanlon, J.T.; Nevitt, M.C.; Whooley, M.A. Central Nervous System Active Medications and Risk for Fractures in Older Women. Arch. Intern. Med. 2003, 163, 949-957. [CrossRef] [PubMed]

561. Woolcott, J.C.; Richardson, K.J.; Wiens, M.O.; Patel, B.; Marin, J.; Khan, K.M.; Marra, A.C. Meta-analysis of the Impact of 9 Medication Classes on Falls in Elderly Persons. Arch. Intern. Med. 2009, 169, 1952-1960. [CrossRef]

562. Tinetti, M.E.; Kumar, C. The Patient Who Falls. JAMA 2010, 303, 258-266. [CrossRef]

563. Huang, A.; Mallet, L.; Buckeridge, D.; Huang, A.R.; Rochefort, C.M.; Eguale, T.; Tamblyn, R. Medication-Related Falls in the Elderly. Drugs Aging 2012, 29, 359-376. [CrossRef]

564. Tinetti, M.E.; Han, L.; Lee, D.S.H.; McAvay, G.J.; Peduzzi, P.; Gross, C.P.; Zhou, B.; Lin, H. Antihypertensive Medications and Serious Fall Injuries in a Nationally Representative Sample of Older Adults. JAMA Intern. Med. 2014, 174, 588-595. [CrossRef]

565. Ham, A.C.; Swart, K.M.; Enneman, A.W.; van Dijk, S.C.; Oliai Araghi, S.; van Wijngaarden, J.P.; van der Zwaluw, N.; Brower-Brolsma, E.M.; Dhonukshe-Rutten, R.A.M.; van Schoor, N.M.L.; et al. Medication-related fall incidents in an older, ambulant population: The B-PROOF study. Drugs Aging 2014, 31, 917-927. [CrossRef]

566. Park, H.; Satoh, H.; Miki, A.; Urushihara, H.; Sawada, Y. Medications associated with falls in older people: Systematic review of publications from a recent 5-year period. Eur. J. Clin. Pharm. 2015, 71, 1429-1440. [CrossRef] [PubMed]

567. Richardson, K.; Bennett, K.; Kenny, R.A. Polypharmacy including falls risk-increasing medications and subsequent falls in community-dwelling middle-aged and older adults. Age Ageing 2014, 44, 90-96. [CrossRef] [PubMed]

568. Ruths, S.; Bakken, M.S.; Ranhoff, A.H.; Hunskaar, S.; Engesæter, L.B.; Engeland, A. Risk of hip fracture among older people using antihypertensive drugs: A nationwide cohort study. BMC Geriatr. 2015, 15, 153. [CrossRef] [PubMed]

569. De Winter, S.; Vanwynsberghe, S.; Foulon, V.; Dejaeger, E.; Flamaing, J.; Sermon, A.; Van Der Linden, L.; Spriet, I. Exploring the relationship between fall risk-increasing drugs and fall-related fractures. Int. J. Clin. Pharm. 2016, 38, 243-251. [CrossRef] [PubMed]

570. Davis, M.P.; Mehta, Z. Opioids and Chronic Pain: Where Is the Balance? Curr. Oncol. Rep. 2016, $18,71$. [CrossRef] 
571. Petty, S.; Wilding, H.; Wark, J.D. Osteoporosis Associated with Epilepsy and the Use of Anti-Epileptics-A Review. Curr. Osteoporos. Rep. 2016, 14, 54-65. [CrossRef]

572. Li, X.; Wu, F.; Zhang, Y.; Yang, J.; Shinohara, A.; Kagami, H. Discontinuation of simvastatin leads to a rebound phenomenon and results in immediate peri-implant bone loss. Clin. Exp. Dent. Res. 2016, 2, 65-72. [CrossRef]

573. Maximos, M.; Chang, F.; Patel, T. Risk of falls associated with antiepileptic drug use in ambulatory elderly populations. Can. Pharm. J. Rev. Des. Pharm. Can. 2017, 150, 101-111. [CrossRef]

574. Ming, Y.; Zecevic, A. Medications \& Polypharmacy Influence on Recurrent Fallers in Community: A Systematic Review. Can. Geriatr. J. 2018, 21, 14-25.

575. Beunza-Sola, M.; Hidalgo-Ovejero, Á.M.; Martí-Ayerdi, J.; Sánchez-Hernández, J.G.; Menéndez-García, M.; García-Mata, S. Study of fall risk-increasing drugs in elderly patients before and after a bone fracture. Postgrad. Med. J. 2017, 94, 76-80. [CrossRef]

576. De Vries, M.; Seppala, L.J.; Daams, J.G.; Van De Glind, E.M.; Masud, T.; Van Der Velde, N.; Blain, H.; Bousquet, J.; Bucht, G.; Caballero-Mora, M.A.; et al. Fall-Risk-Increasing Drugs: A Systematic Review and Meta-Analysis: I. Cardiovascular Drugs. J. Am. Med. Dir. Assoc. 2018, 19, 371.e1-371.e9. [CrossRef] [PubMed]

577. Axmon, A.; Sandberg, M.; Ahlström, G.; Midlöv, P. Fall-risk-increasing drugs and falls requiring health care among older people with intellectual disability in comparison with the general population: A register study. PLoS ONE 2018, 13, e0199218. [CrossRef]

578. Banu, Z.; Lim, K.K.; Kwan, Y.H.; Yap, K.Z.; Ang, H.T.; Tan, C.S.; Fong, W.; Thumboo, J.; Lee, K.H.; Ostbye, T.; et al. Anti-hypertensive medications and injurious falls in an older population of low socioeconomic status: A nested case-control study. BMC Geriatr. 2018, 18, 195. [CrossRef] [PubMed]

579. Hiremath, S.; Ruzicka, M.; Petrcich, W.; McCallum, M.K.; Hundemer, G.L.; Tanuseputro, P.; Manuel, D.; Burns, K.; Edwards, C.; Bugeja, A.; et al. Alpha-Blocker Use and the Risk of Hypotension and Hypotension-Related Clinical Events in Women of Advanced Age. Hypertension 2019, 74, 645-651. [CrossRef] [PubMed]

580. Aspinall, S.L.; Springer, S.P.; Zhao, X.; Cunningham, F.E.; Thorpe, C.T.; Semla, T.P.; Shorr, R.I.; Hanlon, J.T. Central Nervous System Medication Burden and Risk of Recurrent Serious Falls and Hip Fractures in Veterans Affairs Nursing Home Residents. J. Am. Geriatr. Soc. 2018, 67, 74-80. [CrossRef] [PubMed]

581. Toivo, T.; Airaksinen, M.; Dimitrow, M.; Savela, E.; Pelkonen, K.; Kiuru, V.; Suominen, T.; Uunimäki, M.; Kivelä, S.-L.; Leikola, S.; et al. Enhanced coordination of care to reduce medication risks in older home care clients in primary care: A randomized controlled trial. BMC Geriatr. 2019, 19, 332. [CrossRef]

582. Park, H.; Satoh, H.; Miki, A.; Maki, H.; Asai, K.; Shiraishi, A.; Urushihara, H.; Sawada, Y. Medications and fall risk: A case-control study in nursing home residents in Japan. Aging Clin. Exp. Res. 2019, 32, 885-892. [CrossRef]

583. Gray, S.L.A.; Marcum, Z.; Dublin, S.; Walker, R.; Golchin, N.; Rosenberg, E.D.; Bowles, E.J.; Crane, P.; Larson, E.B. Association Between Medications Acting on the Central Nervous System and Fall-Related Injuries in Community-Dwelling Older Adults: A New User Cohort Study. J. Gerontol. Ser. A: Boil. Sci. Med. Sci. 2019, 75, 1003-1009. [CrossRef]

584. Emeny, R.T.; Chang, C.-H.; Skinner, J.; O’Malley, A.J.; Smith, J.; Chakraborti, G.; Rosen, C.J.; Morden, N.E. Association of Receiving Multiple, Concurrent Fracture-Associated Drugs with Hip Fracture Risk. JAMA Netw. Open 2019, 2, e1915348. [CrossRef] [PubMed]

585. Correa-Pérez, A.; Delgado-Silveira, E.; Martín-Aragón, S.; Rojo-Sanchís, A.M.; Cruz-Jentoft, A. Fall-risk increasing drugs and prevalence of polypharmacy in older patients discharged from an Orthogeriatric Unit after a hip fracture. Aging Clin. Exp. Res. 2018, 31, 969-975. [CrossRef]

586. Yue, Q.; Ma, Y.; Teng, Y.; Zhu, Y.; Liu, H.; Xu, S.; Liu, J.; Liu, J.; Zhang, X.; Teng, Z. An updated analysis of opioids increasing the risk of fractures. PLoS ONE 2020, 15, e0220216. [CrossRef] [PubMed]

587. Cardwell, K.; Kerse, N.; Ryan, C.; Teh, R.; Moyes, S.A.; Menzies, O.; Rolleston, A.; Broad, J.; Hughes, C.M. The Association Between Drug Burden Index (DBI) and Health-Related Outcomes: A Longitudinal Study of the 'Oldest Old' (LiLACS NZ). Drugs Aging 2020, 37, 205-213. [CrossRef] [PubMed]

588. Morin, L.; Larrañaga, A.C.; Welmer, A.-K.; Rizzuto, D.; Wastesson, J.W.; Johnell, K. Polypharmacy and injurious falls in older adults: A nationwide nested case-control study. Clin. Epidemiol. 2019, 11, 483-493. [CrossRef] [PubMed] 
589. Solomon, D.H.; Mogun, H.; Garneau, K.; Fischer, A.M. Risk of fractures in older adults using antihypertensive medications. J. Bone Miner. Res. 2011, 26, 1561-1567. [CrossRef]

590. De Groot, M.H.; Van Campen, J.P.C.M.; Moek, M.A.; Tulner, L.R.; Beijnen, J.H.; Lamoth, C.J.C. The Effects of Fall-Risk-Increasing Drugs on Postural Control: A Literature Review. Drugs Aging 2013, 30, 901-920. [CrossRef]

591. Butt, A.D.; Mamdani, M.; Gomes, T.; Lix, L.; Lu, H.; Tu, K. Risk of Osteoporotic Fractures with Angiotensin II Receptor Blockers Versus Angiotensin-Converting Enzyme Inhibitors in Hypertensive Community-Dwelling Elderly. J. Bone Miner. Res. 2014, 29, 2483-2488. [CrossRef]

592. Ang, H.T.; Lim, K.K.; Kwan, Y.H.; Tan, P.S.; Yap, K.Z.; Banu, Z.; Tan, C.S.; Fong, W.; Thumboo, J.; Østbye, T.; et al. A Systematic Review and Meta-Analyses of the Association Between Anti-Hypertensive Classes and the Risk of Falls Among Older Adults. Drugs Aging 2018, 35, 625-635. [CrossRef]

593. Xiao, X.; Xu, Y.; Wu, Q. Thiazide diuretic usage and risk of fracture: A meta-analysis of cohort studies. Osteoporos. Int. 2018, 29, 1515-1524. [CrossRef]

594. Solomon, D.H.; Ruppert, K.; Kazlauskaite, R.; Finkelstein, J.S.; Habel, L.A. Blood pressure lowering medication initiation and fracture risk: A SWAN pharmacoepidemiology study. Arch. Osteoporos. 2019, 14, 73. [CrossRef]

595. Carbone, L.; Vasan, S.; Prentice, R.; Harshfield, G.; Haring, B.; Cauley, J.; Johnson, K. The renin-angiotensin aldosterone system and osteoporosis: Findings from the Women's Health Initiative. Osteoporos. Int. 2019, 30, 2039-2056. [CrossRef]

596. Charkos, T.G.; Liu, Y.; Jin, L.; Yang, S. Thiazide Use and Fracture Risk: An updated Bayesian Meta-Analysis. Sci. Rep. 2019, 9, 19754. [CrossRef] [PubMed]

597. Shea, C.; Witham, M. Association between the Use of Angiotensin-Blocking Medications with Hip Fracture and Death in Older People. J. Frailty Aging 2020, 9, 107-110. [PubMed]

598. Rejnmark, L.; Vestergaard, P.; Mosekilde, L. Treatment with beta-blockers, ACE inhibitors, and calcium-channel blockers is associated with a reduced fracture risk: A nationwide case-control study. J. Hypertens. 2006, 24, 581-589. [CrossRef] [PubMed]

599. Billington, E.O.; Grey, A.; Bolland, M.J. The effect of thiazolidinediones on bone mineral density and bone turnover: Systematic review and meta-analysis. Diabetology 2015, 58, 2238-2246. [CrossRef] [PubMed]

600. Meier, C.; Schwartz, A.V.; Egger, A.; Lecka-Czernik, B. Effects of diabetes drugs on the skeleton. Bone 2016, 82, 93-100. [CrossRef]

601. Chandran, M. Diabetes Drug Effects on the Skeleton. Calcif. Tissue Int. 2016, 100, 133-149. [CrossRef]

602. Adil, M.; Khan, R.A.; Kalam, A.; Venkata, S.K.; Kandhare, A.D.; Ghosh, P.; Sharma, M. Effect of anti-diabetic drugs on bone metabolism: Evidence from preclinical and clinical studies. Pharm. Rep. 2017, 69, 1328-1340. [CrossRef] [PubMed]

603. Wolverton, D.; Blair, M.M. Fracture risk associated with common medications used in treating type 2 diabetes mellitus. Am. J. Health Pharm. 2017, 74, 1143-1151. [CrossRef]

604. Guja, C.; Guja, L.; Miulescu, R.D. Effect of type 2 diabetes medications on fracture risk. Ann. Transl. Med. 2019, 7, 580. [CrossRef]

605. Kalaitzoglou, E.; Fowlkes, J.L.; Popescu, I.; Thrailkill, K.M. Diabetes pharmacotherapy and effects on the musculoskeletal system. Diabetes/Metab. Res. Rev. 2018, 35, e3100. [CrossRef]

606. Yang, Y.-J.; Sheu, B.-S. Metabolic Interaction of Helicobacter pylori Infection and Gut Microbiota. Microorganisms 2016, 4, 15. [CrossRef]

607. Sohl, E.; Van Schoor, N.M.; De Jongh, R.T.; De Vries, O.J.; Lips, P. The impact of medication on vitamin D status in older individuals. Eur. J. Endocrinol. 2011, 166, 477-485. [CrossRef] [PubMed]

608. Van Orten-Luiten, A.C.B.; Janse, A.; Dhonukshe-Rutten, R.A.M.; Witkamp, R.F. The Association Between Drugs Frequently Used by the Elderly and Vitamin D Blood Levels: A Review of Observational and Experimental Studies. Drugs Aging 2014, 31, 111-123. [CrossRef] [PubMed]

609. Van Orten-Luiten, A.C.B.; Janse, A.; Dhonukshe-Rutten, R.A.M.; Witkamp, R.F. Vitamin D deficiency as adverse drug reaction? A cross-sectional study in Dutch geriatric outpatients. Eur. J. Clin. Pharm. 2016, 72, 605-614. [CrossRef] [PubMed]

610. Nordqvist, O.; Svensson, U.L.; Brudin, L.; Wanby, P.; Carlsson, M. Adherence to risk management guidelines for drugs which cause vitamin D deficiency-Big data from the Swedish health system. Drug Healthc. Patient Saf. 2019, 11, 19-28. [CrossRef] [PubMed] 
611. Oliai Araghi, S.; Kiefte-de Jong, J.C.; Trajanoska, K.; Koromani, F.; Rivadeneira, F.; Zillikens, M.C.; van Schoor, N.M.; de Groot, L.C.P.G.M.; Ikram, M.A.; Uitterlinden, A.G.; et al. Do Vitamin D Level and Dietary Calcium Intake Modify the Association Between Loop Diuretics and Bone Health? Calcif Tissue Int. 2020, 106, 104-114. [CrossRef]

612. Stein, E.; Shane, E. Secondary osteoporosis. Endocrinol. Metab. Clin. N. Am. 2003, 32, 115-134. [CrossRef]

613. Painter, S.E.; Kleerekoper, M.; Camacho, P.M. Secondary Osteoporosis: A Review of the Recent Evidence. Endocr. Pract. 2006, 12, 436-445. [CrossRef]

614. Gielen, E.; Vanderschueren, D.; Callewaert, F.; Boonen, S. Osteoporosis in men. Best Pract. Res. Clin. Endocrinol. Metab. 2011, 25, 321-335. [CrossRef]

615. Hudec, S.M.D.; Camacho, P.M. Secondary Causes of Osteoporosis. Endocr. Pract. 2013, 19, $120-128$. [CrossRef]

616. Peacock, M.; Turner, C.H.; Econs, M.J.; Foroud, T. Genetics of Osteoporosis. Endocr. Rev. 2002, 23, $303-326$. [CrossRef] [PubMed]

617. Duncan, E.; Brown, A.M. Mapping genes for osteoporosis-Old dogs and new tricks. Bone 2010, 46, $1219-1225$. [CrossRef] [PubMed]

618. Duncan, E.; Brown, A.M.; Shore, E.M. The Revolution in Human Monogenic Disease Mapping. Genes 2014, 5, 792-803. [CrossRef] [PubMed]

619. Kannus, P.; Palvanen, M.; Kaprio, J.; Parkkari, J.; Koskenvuo, M. Genetic factors and osteoporotic fractures in elderly people: Prospective 25 year follow up of a nationwide cohort of elderly Finnish twins. BMJ 1999, 319, 1334-1337. [CrossRef]

620. Michaëlsson, K.; Melhus, H.; Ferm, H.; Ahlbom, A.; Pedersen, N.L. Genetic Liability to Fractures in the Elderly. Arch. Intern. Med. 2005, 165, 1825-1830. [CrossRef] [PubMed]

621. MacGregor, A.J.; Snieder, H.; Spector, T.D. Genetic factors and osteoporotic fractures in elderly people. Twin data support genetic contribution to risk of fracture. BMJ 2000, 320, 1669. [CrossRef] [PubMed]

622. Deng, H.-W.; Chen, W.-M.; Recker, S.; Stegman, M.R.; Li, J.-L.; Davies, K.M.; Zhou, Y.; Deng, H.; Heaney, R.; Recker, R.R. Genetic Determination of Colles' Fracture and Differential Bone Mass in Women With and Without Colles' Fracture. J. Bone Miner. Res. 2000, 15, 1243-1252. [CrossRef] [PubMed]

623. Deng, H.-W.; Mahaney, M.C.; Williams, J.T.; Li, J.; Conway, T.; Davies, K.M.; Li, J.-L.; Deng, H.; Recker, R.R. Relevance of the genes for bone mass variation to susceptibility to osteoporotic fractures and its implications to gene search for complex human diseases. Genet. Epidemiol. 2001, 22, 12-25. [CrossRef]

624. Andrew, T.; Antioniades, L.; Scurrah, K.J.; Macgregor, A.J.; Spector, T.D. Risk of wrist fracture in women is heritable and is influenced by genes that are largely independent of those influencing BMD. J. Bone Miner. Res. 2005, 20, 67-74. [CrossRef]

625. Carmelli, D.; Kelly-Hayes, M.; Wolf, P.A.; Swan, G.E.; Jack, L.M.; Reed, T.; Guralnik, J.M. The contribution of genetic influences to measures of lower-extremity function in older male twins. J. Gerontol. Ser. A: Biol. Sci. Med. Sci. 2000, 55, B49-B53.

626. Roth, S.M. Genetic aspects of skeletal muscle strength and mass with relevance to sarcopenia. Bonekey Rep. 2012, 1, 58. [CrossRef] [PubMed]

627. Just, K.S.; Schneider, K.L.; Schurig, M.; Stingl, J.; Brockmöller, J. Falls: The adverse drug reaction of the elderly and the impact of pharmacogenetics. Pharmacogenomics 2017, 18, 1281-1297. [CrossRef] [PubMed]

628. Cummings, S.R. Pharmacologic treatment to prevent fractures: From markers to patients. Osteoporos. Int. 2009, 20 (Suppl. 3), S255-S256. [CrossRef]

629. Poudyal, H.; Brown, L. Osteoporosis and its association with non-gonadal hormones involved in hypertension, adiposity and hyperglycaemia. Curr. Drug Targets 2013, 14, 1694-1706. [CrossRef] [PubMed]

630. Khosla, S.; Shane, E. A Crisis in the Treatment of Osteoporosis. J. Bone Miner. Res. 2016, 31, $1485-1487$. [CrossRef]

631. Viswanathan, M.; Reddy, S.; Berkman, N.; Cullen, K.; Middleton, J.C.; Nicholson, W.K.; Kahwati, L.C. Screening to Prevent Osteoporotic Fractures. JAMA 2018, 319, 2532-2551. [CrossRef]

632. Zeng, L.-F.; Pan, B.-Q.; Liang, G.-H.; Luo, M.-H.; Cao, Y.; Guo, D.; Chen, H.-Y.; Pan, J.-K.; Huang, H.-T.; Liu, Q.; et al. Does Routine Anti-Osteoporosis Medication Lower the Risk of Fractures in Male Subjects? An Updated Systematic Review With Meta-Analysis of Clinical Trials. Front. Pharm. 2019, 10, 882. [CrossRef] 
633. Weaver, C.M.; Gordon, C.M.; Janz, K.F.; Kalkwarf, H.J.; Lappe, J.M.; Lewis, R.; O’Karma, M.; Wallace, T.C.; Zemel, B.S. The National Osteoporosis Foundation's position statement on peak bone mass development and lifestyle factors: A systematic review and implementation recommendations. Osteoporos. Int. 2016, 27, 1281-1386. [CrossRef]

634. Pripp, A.H.; Dahl, O.E. The Population Attributable Risk of Nutrition and Lifestyle on Hip Fractures. Hip Int. 2015, 25, 277-281. [CrossRef]

635. Trajanoska, K.; Rivadeneira, F. The genetic architecture of osteoporosis and fracture risk. Bone 2019, 126, 2-10. [CrossRef]

636. Larsson, S.C.; Melhus, H.; Michaëlsson, K. Circulating Serum 25-Hydroxyvitamin D Levels and Bone Mineral Density: Mendelian Randomization Study. J. Bone Miner. Res. 2018, 33, 840-844. [CrossRef] [PubMed]

637. Dong, H.; Zhou, W.; Wang, P.; Zuo, E.; Ying, X.; Chai, S.; Fei, T.; Jin, L.; Chen, C.; Ma, G.; et al. Comprehensive Analysis of the Genetic and Epigenetic Mechanisms of Osteoporosis and Bone Mineral Density. Front. Cell Dev. Biol. 2020, 8, 194. [CrossRef] [PubMed]

638. Nethander, M.; Vandenput, L.; Eriksson, A.L.; Windahl, S.; Funck-Brentano, T.; Ohlsson, C. Evidence of a Causal Effect of Estradiol on Fracture Risk in Men. J. Clin. Endocrinol. Metab. 2018, 104, 433-442. [CrossRef] [PubMed]

639. Du, Y.; Li, P.; Wen, Y.; Liang, X.; Liu, L.; Cheng, B.; Ding, M.; Zhao, Y.; Ma, M.; Zhang, L.; et al. Evaluating the Correlations Between Osteoporosis and Lifestyle-Related Factors Using Transcriptome-Wide Association Study. Calcif. Tissue Int. 2019, 106, 256-263. [CrossRef] [PubMed]

640. Cerani, A.; Zhou, S.; Forgetta, V.; Morris, J.A.; Trajanoska, K.; Rivadeneira, F.; Larsson, S.C.; Michaëlsson, K.; Richards, J.B. Genetic predisposition to increased serum calcium, bone mineral density, and fracture risk in individuals with normal calcium levels: Mendelian randomisation study. BMJ 2019, 366, 14410. [CrossRef] [PubMed]

641. Oei, L.; Campos-Obando, N.; Dehghan, A.; Oei, E.H.G.; Stolk, L.; Van Meurs, J.B.J.; Hofman, A.; Uitterlinden, A.G.; Franco, O.H.; Zillikens, M.C.; et al. Dissecting the relationship between high-sensitivity serum C-reactive protein and increased fracture risk: The Rotterdam Study. Osteoporos. Int. 2013, 25, 1247-1254. [CrossRef]

642. Huang, J.V.; Schooling, C.M. Inflammation and bone mineral density: A Mendelian randomization study. Sci. Rep. 2017, 7, 8666. [CrossRef]

643. Gan, W.; Clarke, R.J.; Mahajan, A.; Kulohoma, B.W.; Kitajima, H.; Robertson, N.R.; Rayner, N.W.; Walters, R.G.; Holmes, M.V.; Chen, Z.; et al. Bone mineral density and risk of type 2 diabetes and coronary heart disease: A Mendelian randomization study. Wellcome Open Res. 2017, 2, 68. [CrossRef]

644. Cui, Z.; Meng, X.; Zhuang, S.; Liu, Z.; Zhou, F.; Tian, Y. Schizophrenia, Bipolar Disorder, and Alzheimer's Disease are not Causal Factors of Bone Mineral Density: A Mendelian Randomization Analysis. Calcif. Tissue Int. 2019, 106, 131-146. [CrossRef]

645. Guo, R.; Wu, L.; Fu, Q. Is There Causal Relationship of Smoking and Alcohol Consumption with Bone Mineral Density? A Mendelian Randomization Study. Calcif. Tissue Int. 2018, 103, 546-553. [CrossRef]

646. Collaborators GBDCoD. Global, regional, and national age-sex-specific mortality for 282 causes of death in 195 countries and territories, 1980-2017: A systematic analysis for the Global Burden of Disease Study 2017. Lancet 2018, 392, 1736-1788. [CrossRef]

647. Gaskell, H.; Derry, S.; Moore, R.A.; McQuay, H.J. Prevalence of anaemia in older persons: Systematic review. BMC Geriatr. 2008, 8, 1. [CrossRef] [PubMed]

648. Kassebaum, N.J.; Jasrasaria, R.; Naghavi, M.; Wulf, S.K.; Johns, N.; Lozano, R.; Regan, M.; Weatherall, D.; Chou, D.P.; Eisele, T.P.; et al. A systematic analysis of global anemia burden from 1990 to 2010. Blood 2014, 123, 615-624. [CrossRef] [PubMed]

649. Cappellini, M.D.; Musallam, K.M.; Taher, A.T. Iron deficiency anaemia revisited. J. Intern. Med. 2019, 287, 153-170. [CrossRef]

650. Donaldson, A.I.; Soiza, R.L.; Hands, K.J.; Witham, M.D.; Myint, P.K. Variability in the clinical management of iron deficiency anaemia in older adults: Results from a survey of UK specialists in the care of older people. Adv. Drug Saf. 2019, 10, 2042098619854870. [CrossRef]

651. Fuggle, N.R.; Curtis, E.M.; Ward, K.A.; Harvey, N.C.; Dennison, E.M.; Cooper, C. Fracture prediction, imaging and screening in osteoporosis. Nat. Rev. Endocrinol. 2019, 15, 535-547. [CrossRef] 
652. Cheung, C.-L.; Tan, K.C.; Kung, A.W.C. Cohort Profile: The Hong Kong Osteoporosis Study and the follow-up study. Int. J. Epidemiol. 2017, 47, 397-8f. [CrossRef]

653. Cao, L.; Yu, J.; Cao, L.; Yu, J. Effect of Helicobacter pylori Infection on the Composition of Gastric Microbiota in the Development of Gastric Cancer. Gastrointest. Tumors 2015, 2, 14-25. [CrossRef]

654. Yap, T.W.-C.; Gan, H.M.; Lee, Y.-P.; Leow, A.H.-R.; Azmi, A.N.; Francois, F.; Perez, G.I.P.; Loke, M.F.; Goh, K.-L.; Vadivelu, J. Helicobacter pylori Eradication Causes Perturbation of the Human Gut Microbiome in Young Adults. PLoS ONE 2016, 11, e0151893. [CrossRef]

655. Wroblewski, L.E.; Peek, R.M., Jr. Helicobacter pylori, Cancer, and the Gastric Microbiota. Adv. Exp. Med. Biol. 2016, 908, 393-408.

656. Parsons, B.N.; Ijaz, U.Z.; D'Amore, R.; Burkitt, M.D.; Eccles, R.; Lenzi, L.; Duckworth, C.A.; Moore, A.R.; Tiszlavicz, L.; Varro, A.; et al. Comparison of the human gastric microbiota in hypochlorhydric states arising as a result of Helicobacter pylori-induced atrophic gastritis, autoimmune atrophic gastritis and proton pump inhibitor use. PLoS Pathog. 2017, 13, e1006653. [CrossRef]

657. Alarcón, T.; Llorca, L.; Perez, G.I.P. Impact of the Microbiota and Gastric Disease Development by Helicobacter pylori. Future HIV 1 Ther. 2017, 400, 253-275.

658. Chen, L.; Xu, W.; Lee, A.; He, J.; Huang, B.; Zheng, W.; Su, T.; Lai, S.; Long, Y.; Chu, H.; et al. The impact of Helicobacter pylori infection, eradication therapy and probiotic supplementation on gut microenvironment homeostasis: An open-label, randomized clinical trial. EBioMedicine 2018, 35, 87-96. [CrossRef]

659. Schulz, C.; Schütte, K.; Koch, N.; Vilchez-Vargas, R.; Wos-Oxley, M.L.; Oxley, A.A.P.; Vital, M.; Malfertheiner, P.; Pieper, D.H. The active bacterial assemblages of the upper GI tract in individuals with and without Helicobacter infection. Gut 2016, 67, 216-225. [CrossRef] [PubMed]

660. Gao, J.-J.; Zhang, Y.; Gerhard, M.; Mejias-Luque, R.; Zhang, L.; Vieth, M.; Ma, J.-L.; Bajbouj, M.; Suchanek, S.; Liu, W.-D.; et al. Association Between Gut Microbiota and Helicobacter pylori-Related Gastric Lesions in a High-Risk Population of Gastric Cancer. Front. Cell. Infect. Microbiol. 2018, 8, 202. [CrossRef] [PubMed]

661. Pero, R.; Brancaccio, M.; Laneri, S.; De Biasi, M.G.; Lombardo, B.; Scudiero, O. A Novel View of Human Helicobacter pylori Infections: Interplay between Microbiota and Beta-Defensins. Biomology 2019, 9, 237. [CrossRef] [PubMed]

662. Pichon, M.; Burucoa, C. Impact of the Gastro-Intestinal Bacterial Microbiome on Helicobacter-Associated Diseases. Healthcare 2019, 7, 34. [CrossRef] [PubMed]

663. Dash, N.R.; Khoder, G.; Nada, A.M.; Al Bataineh, M.T. Exploring the impact of Helicobacter pylori on gut microbiome composition. PLoS ONE 2019, 14, e0218274. [CrossRef]

664. Iino, C.; Shimoyama, T.; Chinda, D.; Sakuraba, H.; Fukuda, S.; Nakaji, S. Influence of Helicobacter pylori Infection and Atrophic Gastritis on the Gut Microbiota in a Japanese Population. Digestion 2019, 8, 1-11. [CrossRef]

665. Frost, F.; Kacprowski, T.; Rühlemann, M.C.; Bang, C.; Franke, A.; Zimmermann, K.; Nauck, M.; Völker, U.; Völzke, H.; Biffar, R.; et al. Helicobacter pylori infection associates with fecal microbiota composition and diversity. Sci. Rep. 2019, 9, 20100. [CrossRef]

666. Wang, D.; Li, Y.; Zhong, H.; Ding, Q.; Lin, Y.; Tang, S.; Zong, Y.; Wang, Q.; Zhang, X.; Yang, H.; et al. Alterations in the human gut microbiome associated with Helicobacter pylori infection. FEBS Openbio 2019, 9, 1552-1560. [CrossRef]

667. Yang, L.; Zhang, J.; Xu, J.; Wei, X.; Yang, J.; Liu, Y.; Li, H.; Zhao, C.; Wang, Y.; Zhang, L.; et al. Helicobacter pylori Infection Aggravates Dysbiosis of Gut Microbiome in Children with Gastritis. Front. Cell. Infect. Microbiol. 2019, 9, 375. [CrossRef] [PubMed]

668. Heimesaat, M.M.; Fischer, A.; Plickert, R.; Wiedemann, T.; Loddenkemper, C.; Göbel, U.B.; Bereswill, S.; Rieder, G. Helicobacter pylori Induced Gastric Immunopathology Is Associated with Distinct Microbiota Changes in the Large Intestines of Long-Term Infected Mongolian Gerbils. PLoS ONE 2014, 9, e100362. [CrossRef] [PubMed]

669. Sjogren, K.; Engdahl, C.; Henning, P.; Lerner, U.H.; Tremaroli, V.; Lagerquist, M.K.; Bäckhed, F.; Ohlsson, C. The gut microbiota regulates bone mass in mice. J. Bone Miner. Res. 2012, 27, 1357-1367. [CrossRef]

670. Ohlsson, C.; Sjögren, K. Effects of the gut microbiota on bone mass. Trends Endocrinol. Metab. 2015, $26,69-74$. [CrossRef] [PubMed]

671. Weaver, C.M. Diet, gut microbiome, and bone health. Curr. Osteoporos. Rep. 2015, 13, 125-130. [CrossRef]

672. Hernandez, C.J. Bone Mechanical Function and the Gut Microbiota. Adv. Exp. Med. Biol. 2017, 1033, $249-270$. 
673. Wang, J.; Wang, Y.; Gao, W.; Wang, B.; Zhao, H.; Zeng, Y.; Ji, Y.; Hao, D. Diversity analysis of gut microbiota in osteoporosis and osteopenia patients. PeerJ 2017, 5, e3450. [CrossRef] [PubMed]

674. Quach, D.; Britton, R.A. Gut Microbiota and Bone Health. Polyglutamine Disord. 2017, 1033, 47-58.

675. Yan, J.; Charles, J.F. Gut Microbiome and Bone: To Build, Destroy, or Both? Curr. Osteoporos. Rep. 2017, 15, 376-384. [CrossRef]

676. Chen, Y.-C.; Greenbaum, J.; Shen, H.; Deng, H.-W. Association Between Gut Microbiota and Bone Health: Potential Mechanisms and Prospective. J. Clin. Endocrinol. Metab. 2017, 102, 3635-3646. [CrossRef] [PubMed]

677. D'Amelio, P.; Sassi, F. Gut Microbiota, Immune System, and Bone. Calcif. Tissue Int. 2017, 102, 415-425. [CrossRef] [PubMed]

678. Jones, R.M.; Mulle, J.G.; Pacifici, R. Osteomicrobiology: The influence of gut microbiota on bone in health and disease. Bone 2018, 115, 59-67. [CrossRef] [PubMed]

679. Yan, J.; Takakura, A.; Zandi-Nejad, K.; Charles, J.F. Mechanisms of gut microbiota-mediated bone remodeling. Gut Microbes 2017, 9, 84-92. [CrossRef] [PubMed]

680. Ohlsson, C.; Sjögren, K. Osteomicrobiology: A New Cross-Disciplinary Research Field. Calcif. Tissue Int. 2017, 102, 426-432. [CrossRef] [PubMed]

681. Feng, Q.; Chen, W.-D.; Wang, Y.-D. Gut Microbiota: An Integral Moderator in Health and Disease. Front. Microbiol. 2018, 9, 151. [CrossRef] [PubMed]

682. Rajoka, M.S.R.; Zhao, H.; Li, N.; Lu, Y.; Lian, Z.; Shao, D.; Jin, M.; Li, Q.; Zhao, L.; Shi, J. Origination, change, and modulation of geriatric disease-related gut microbiota during life. Appl. Microbiol. Biotechnol. 2018, 102, 8275-8289. [CrossRef]

683. Das, M.; Cronin, O.; Keohane, D.M.; Cormac, E.M.; Nugent, H.; Nugent, M.; Molloy, C.; O’Toole, P.W.; Shanahan, F.; Molloy, M.G.; et al. Gut microbiota alterations associated with reduced bone mineral density in older adults. Rheumatology 2019, 58, 2295-2304. [CrossRef]

684. Hao, M.-L.; Wang, G.-Y.; Zuo, X.-Q.; Qu, C.-J.; Yao, B.-C.; Wang, D.-L. Gut microbiota: An overlooked factor that plays a significant role in osteoporosis. J. Int. Med. Res. 2019, 47, 4095-4103. [CrossRef]

685. Zaiss, M.M.; Jones, R.M.; Schett, G.; Pacifici, R. The gut-bone axis: How bacterial metabolites bridge the distance. J. Clin. Investig. 2019, 129, 3018-3028. [CrossRef]

686. Ibáñez, L.; Rouleau, M.; Wakkach, A.; Blin-Wakkach, C. Gut microbiome and bone. Jt. Bone Spine 2019, 86, 43-47. [CrossRef] [PubMed]

687. Rizzoli, R. Nutritional influence on bone: Role of gut microbiota. Aging Clin. Exp. Res. 2019, 31, 743-751. [CrossRef] [PubMed]

688. Biver, E.; Berenbaum, F.; Valdes, A.M.; De Carvalho, I.A.; Bindels, L.B.; Brandi, M.L.; Calder, P.C.; Castronovo, V.; Cavalier, E.; Cherubini, A.; et al. Gut microbiota and osteoarthritis management: An expert consensus of the European society for clinical and economic aspects of osteoporosis, osteoarthritis and musculoskeletal diseases (ESCEO). Ageing Res. Rev. 2019, 55, 100946. [CrossRef] [PubMed]

689. Ii, D.Y.; Pan, K.; Shendge, V.B.; Liu, J.; Ebraheim, A.N. Linkage of microbiota and osteoporosis: A mini literature review. World J. Orthop. 2019, 10, 123-127. [CrossRef]

690. Dutta, S.K.; Verma, S.; Jain, V.; Surapaneni, B.K.; Vinayek, R.; Phillips, L.; Nair, P.P. Transplantation. J. Neurogastroenterol. Motil. 2019, 25, 363-376. [CrossRef]

691. Li, C.; Huang, Q.; Yang, R.; Dai, Y.; Zeng, Y.; Tao, L.; Li, X.; Zeng, J.; Wang, Q. Gut microbiota composition and bone mineral loss-Epidemiologic evidence from individuals in Wuhan, China. Osteoporos. Int. 2019, 30, 1003-1013. [CrossRef]

692. Hathaway-Schrader, J.D.; Steinkamp, H.M.; Chavez, M.B.; Poulides, N.A.; Kirkpatrick, J.E.; Chew, M.E.; Huang, E.; Alekseyenko, A.; Aguirre, J.; Novince, C.M. Antibiotic Perturbation of Gut Microbiota Dysregulates Osteoimmune Cross Talk in Postpubertal Skeletal Development. Am. J. Pathol. 2019, 189, 370-390. [CrossRef]

693. Li, L.; Rao, S.; Cheng, Y.; Zhuo, X.; Deng, C.; Xu, N.; Zhang, H.; Yang, L. Microbial osteoporosis: The interplay between the gut microbiota and bones via host metabolism and immunity. MicrobiologyOpen 2019, 8, e00810. [CrossRef]

694. Xie, W.; Han, Y.; Li, F.; Gu, X.; Su, D.; Yu, W.; Li, Z.; Xiao, J. Neuropeptide Y1 Receptor Antagonist Alters Gut Microbiota and Alleviates the Ovariectomy-Induced Osteoporosis in Rats. Calcif. Tissue Int. 2019, 106, 444-454. [CrossRef]

695. Behera, J.; Ison, J.; Tyagi, S.C.; Tyagi, N. The role of gut microbiota in bone homeostasis. Bone 2020, 135, 115317. [CrossRef] 
696. Ohlsson, C.; Engdahl, C.; Fåk, F.; Andersson, A.; Windahl, S.H.; Farman, H.H.; Movérare-Skrtic, S.; Islander, U.; Sjögren, K. Probiotics Protect Mice from Ovariectomy-Induced Cortical Bone Loss. PLoS ONE 2014, 9, e92368. [CrossRef] [PubMed]

697. Hsu, E.; Pacifici, R. From Osteoimmunology to Osteomicrobiology: How the Microbiota and the Immune System Regulate Bone. Calcif. Tissue Int. 2017, 102, 512-521. [CrossRef] [PubMed]

698. Zhang, J.; Zhang, J.; Wang, R. Gut microbiota modulates drug pharmacokinetics. Drug Metab. Rev. 2018, 50, 357-368. [CrossRef] [PubMed]

699. Locantore, P.; Del Gatto, V.; Gelli, S.; Paragliola, R.M.; Pontecorvi, A. The Interplay between Immune System and Microbiota in Osteoporosis. Mediat. Inflamm. 2020, 2020, 3686749. [CrossRef] [PubMed]

700. Clemente, J.C.; Manasson, J.; Scher, J.U. The role of the gut microbiome in systemic inflammatory disease. BMJ 2018, 360, j5145. [CrossRef]

701. Jackson, M.A.; Verdi, S.; Maxan, M.-E.; Shin, C.M.; Zierer, J.; Bowyer, R.C.E.; Martin, T.C.; Williams, F.M.K.; Menni, C.; Bell, J.T.; et al. Gut microbiota associations with common diseases and prescription medications in a population-based cohort. Nat. Commun. 2018, 9, 2655. [CrossRef]

702. Gentile, C.L.; Weir, T.L. The gut microbiota at the intersection of diet and human health. Science 2018, 362, 776-780. [CrossRef]

703. Valdes, A.M.; Walter, J.; Segal, E.; Spector, T.D. Role of the gut microbiota in nutrition and health. BMJ 2018, 361, k2179. [CrossRef]

704. Kim, S.; Jazwinski, S.M. The Gut Microbiota and Healthy Aging: A Mini-Review. Gerontology 2018, 64, 513-520. [CrossRef]

705. Osadchiy, V.; Martin, C.R.; Mayer, E.A. Gut Microbiome and Modulation of CNS Function. Compr. Physiol. 2019, 10, 57-72.

706. Martin, A.M.; Sun, E.W.; Rogers, G.B.; Keating, D.J. The Influence of the Gut Microbiome on Host Metabolism Through the Regulation of Gut Hormone Release. Front. Physiol. 2019, 10, 428. [CrossRef] [PubMed]

707. Ma, Q.; Xing, C.; Long, W.; Wang, H.Y.; Liu, Q.; Wang, R.-F. Impact of microbiota on central nervous system and neurological diseases: The gut-brain axis. J. Neuroinflammation 2019, 16, 53. [CrossRef] [PubMed]

708. Tanaka, M.; Itoh, H. Hypertension as a Metabolic Disorder and the Novel Role of the Gut. Curr. Hypertens. Rep. 2019, 21, 3. [CrossRef] [PubMed]

709. Ilie, O.D.; Ciobica, A.; McKenna, J.; Doroftei, B.; Mavroudis, I. Minireview on the Relations between Gut Microflora and Parkinson's Disease: Further Biochemical (Oxidative Stress), Inflammatory, and Neurological Particularities. Oxid. Med. Cell Longev. 2020, 2020, 4518023. [CrossRef] [PubMed]

710. Preidis, A.G.; Versalovic, J. Targeting the Human Microbiome with Antibiotics, Probiotics, and Prebiotics: Gastroenterology Enters the Metagenomics Era. Gastroenterology 2009, 136, 2015-2031. [CrossRef]

711. Zhernakova, A.; Kurilshikov, A.; Bonder, M.J.; Tigchelaar, E.F.; Schirmer, M.; Vatanen, T.; Mujagic, Z.; Vila, A.V.; Falony, G.; Vieira-Silva, S.; et al. Population-based metagenomics analysis reveals markers for gut microbiome composition and diversity. Science 2016, 352, 565-569. [CrossRef]

712. Falony, G.; Joossens, M.; Vieira-Silva, S.; Wang, J.; Darzi, Y.; Faust, K.; Kurilshikov, A.; Bonder, M.J.; Valles-Colomer, M.; Vandeputte, D.; et al. Population-level analysis of gut microbiome variation. Science 2016, 352, 560-564. [CrossRef]

713. Sterbini, F.P.; Palladini, A.; Masucci, L.; Cannistraci, C.V.; Pastorino, R.; Ianiro, G.; Bugli, F.; Martini, C.; Ricciardi, W.; Gasbarrini, A.; et al. Effects of Proton Pump Inhibitors on the Gastric Mucosa-Associated Microbiota in Dyspeptic Patients. Appl. Environ. Microbiol. 2016, 82, 6633-6644. [CrossRef]

714. Ticinesi, A.; Milani, C.; Lauretani, F.; Nouvenne, A.; Mancabelli, L.; Lugli, G.A.; Turroni, F.; Duranti, S.; Mangifesta, M.; Viappiani, A.; et al. Gut microbiota composition is associated with polypharmacy in elderly hospitalized patients. Sci. Rep. 2017, 7, 11102. [CrossRef]

715. Imhann, F.; Vila, A.V.; Bonder, M.J.; Manosalva, A.G.L.; Koonen, D.P.; Fu, J.; Wijmenga, C.; Zhernakova, A.; Weersma, R.K. The influence of proton pump inhibitors and other commonly used medication on the gut microbiota. Gut Microbes 2017, 8, 351-358. [CrossRef]

716. Maier, L.; Pruteanu, M.; Kuhn, M.; Zeller, G.; Telzerow, A.; Anderson, E.E.; Brochado, A.R.; Fernandez, K.C.; Dose, H.; Mori, H.; et al. Extensive impact of non-antibiotic drugs on human gut bacteria. Nat. Cell Biol. 2018, 555, 623-628. [CrossRef] [PubMed] 
717. Le Bastard, Q.; Al-Ghalith, G.A.; Grégoire, M.; Chapelet, G.; Javaudin, F.; Dailly, E.; Batard, E.; Knights, D.; Montassier, E. Systematic review: Human gut dysbiosis induced by non-antibiotic prescription medications. Aliment. Pharm. 2017, 47, 332-345. [CrossRef] [PubMed]

718. Bruno, G.; Zaccari, P.; Rocco, G.; Scalese, G.; Panetta, C.; Porowska, B.; Pontone, S.; Severi, C. Proton pump inhibitors and dysbiosis: Current knowledge and aspects to be clarified. World J. Gastroenterol. 2019, 25, 2706-2719. [CrossRef] [PubMed]

719. Hi, Y.-C.; Cai, S.-T.; Tian, Y.-P.; Zhao, H.-J.; Zhang, Y.-B.; Chen, J.; Ren, R.-R.; Luo, X.; Peng, L.-H.; Sun, G.; et al. Effects of Proton Pump Inhibitors on the Gastrointestinal Microbiota in Gastroesophageal Reflux Disease. Genom. Proteom. Bioinform. 2019, 17, 52-63.

720. Vila, A.V.; Collij, V.; Sanna, S.; Sinha, T.; Imhann, F.; Bourgonje, A.R.; Mujagic, Z.; Jonkers, D.M.A.E.; Masclee, A.A.M.; Fu, J.; et al. Impact of commonly used drugs on the composition and metabolic function of the gut microbiota. Nat. Commun. 2020, 11, 362. [CrossRef] [PubMed]

721. Rajilic-Stojanovic, M.; Figueiredo, C.; Smet, A.; Hansen, R.; Kupcinskas, J.; Rokkas, T.; Andersen, L.; Machado, J.C.; Ianiro, G.; Gasbarrini, A.; et al. Systematic review: Gastric microbiota in health and disease. Aliment. Pharm. 2020, 51, 582-602. [CrossRef]

722. Clooney, A.G.; Bernstein, C.N.; Leslie, W.D.; Vagianos, K.; Sargent, M.; Laserna-Mendieta, E.J.; Claesson, M.J.; Targownik, L.E. A comparison of the gut microbiome between long-term users and non-users of proton pump inhibitors. Aliment. Pharm. 2016, 43, 974-984. [CrossRef]

723. Minalyan, A.; Gabrielyan, L.; Scott, D.; Jacobs, J.; Pisegna, J.R. The Gastric and Intestinal Microbiome: Role of Proton Pump Inhibitors. Curr. Gastroenterol. Rep. 2017, 19, 42. [CrossRef]

724. Takagi, T.; Naito, Y.; Inoue, R.; Kashiwagi, S.; Uchiyama, K.; Mizushima, K.; Tsuchiya, S.; Okayama, T.; Dohi, O.; Yoshida, N.; et al. The influence of long-term use of proton pump inhibitors on the gut microbiota: An age-sex-matched case-control study. J. Clin. Biochem. Nutr. 2018, 62, 100-105. [CrossRef]

725. Hojo, M.; Asahara, T.; Nagahara, A.; Takeda, T.; Matsumoto, K.; Ueyama, H.; Matsumoto, K.; Asaoka, D.; Takahashi, T.; Nomoto, K.; et al. Gut Microbiota Composition Before and After Use of Proton Pump Inhibitors. Dig. Dis. Sci. 2018, 63, 2940-2949. [CrossRef]

726. Naito, Y.; Kashiwagi, K.; Takagi, T.; Andoh, A.; Inoue, R. Intestinal Dysbiosis Secondary to Proton-Pump Inhibitor Use. Digestion 2018, 97, 195-204. [CrossRef] [PubMed]

727. Imhann, F.; Bonder, M.J.; Vila, A.V.; Fu, J.; Mujagic, Z.; Vork, L.; Tigchelaar, E.F.; Jankipersadsing, A.S.; Cenit, M.C.; Harmsen, H.J.M.; et al. Proton pump inhibitors affect the gut microbiome. Gut 2015, 65, 740-748. [CrossRef] [PubMed]

728. Macke, L.; Schulz, C.; Koletzko, L.; Malfertheiner, P. Systematic review: The effects of proton pump inhibitors on the microbiome of the digestive tract-evidence from next-generation sequencing studies. Aliment. Pharm. 2020, 51, 505-526. [CrossRef] [PubMed]

729. He, C.; Peng, C.; Wang, H.; Ouyang, Y.; Zhu, Z.; Shu, X.; Zhu, Y.; Lu, N.-H. The eradication of Helicobacter pylori restores rather than disturbs the gastrointestinal microbiota in asymptomatic young adults. Helicobacter 2019, 24, e12590. [CrossRef]

730. Scholz-Ahrens, K.E.; Ade, P.; Marten, B.; Weber, P.; Timm, W.; A çl, Y.; Glüer, C.-C.; Schrezenmeir, J. Prebiotics, Probiotics, and Synbiotics Affect Mineral Absorption, Bone Mineral Content, and Bone Structure. J. Nutr. 2007, 137, 838S-846S. [CrossRef] [PubMed]

731. Roberfroid, M.; Gibson, G.R.; Hoyles, L.; McCartney, A.L.; Rastall, R.; Rowland, I.; Wolvers, D.; Watzl, B.; Szajewska, H.; Stahl, B.; et al. Prebiotic effects: Metabolic and health benefits. Br. J. Nutr. 2010, 104 (Suppl. 2), S1-S63. [CrossRef]

732. McCabe, L.R.; Britton, R.A.; Parameswaran, N. Prebiotic and Probiotic Regulation of Bone Health: Role of the Intestine and its Microbiome. Curr. Osteoporos. Rep. 2015, 13, 363-371. [CrossRef]

733. Schepper, J.D.; Irwin, R.; Kang, J.; Dagenais, K.; Lemon, T.; Shinouskis, A.; Parameswaran, N.; McCabe, L.R. Probiotics in Gut-Bone Signaling. Adv. Exp. Med. Biol. 2017, 1033, 225-247.

734. Collins, F.L.; Schepper, J.D.; Rios-Arce, N.D.; Steury, M.D.; Kang, H.J.; Mallin, H.; Schoenherr, D.; Camfield, G.; Chishti, S.; McCabe, L.R.; et al. Immunology of Gut-Bone Signaling. Adv. Exp. Med. Biol. 2017, 1033, $59-94$.

735. McCabe, L.R.; Parameswaran, N. Advances in Probiotic Regulation of Bone and Mineral Metabolism. Calcif. Tissue Int. 2018, 102, 480-488. [CrossRef] 
736. Cornejo-Pareja, I.; Martín-Núñez, G.M.; Roca-Rodríguez, M.M.; Cardona, F.; Coin-Aragüez, L.; Sanchez-Alcoholado, L.; Gutiérrez-Repiso, C.; Muñoz-Garach, A.; Fernández-García, J.C.; Queipo-Ortuño, M.I.; et al. H. pylori Eradication Treatment Alters Gut Microbiota and GLP-1 Secretion in Humans. J. Clin. Med. 2019, 8, 451. [CrossRef] [PubMed]

737. Whisner, C.M.; Castillo, L.F. Prebiotics, Bone and Mineral Metabolism. Calcif. Tissue Int. 2017, 102, $443-479$. [CrossRef] [PubMed]

738. Lucas, G. Gut thinking: The gut microbiome and mental health beyond the head. Microb. Ecol. Health Dis. 2018, 29, 1548250. [CrossRef] [PubMed]

739. Takimoto, T.; Hatanaka, M.; Hoshino, T.; Takara, T.; Tanaka, K.; Shimizu, A.; Morita, H.; Nakamura, T. Effect of Bacillus subtilis C-3102 on bone mineral density in healthy postmenopausal Japanese women: A randomized, placebo-controlled, double-blind clinical trial. Biosci. Microbiota Food Health 2018, 37, 87-96. [CrossRef] [PubMed]

740. Kiousi, D.E.; Karapetsas, A.; Karolidou, K.; Panayiotidis, M.I.; Pappa, A.; Galanis, A. Probiotics in Extraintestinal Diseases: Current Trends and New Directions. Nutrients 2019, 11, 788. [CrossRef]

741. Curtis, E.M.; Moon, R.J.; Harvey, N.C.; Cooper, C. The impact of fragility fracture and approaches to osteoporosis risk assessment worldwide. Bone 2017, 104, 29-38. [CrossRef]

742. Court-Brown, C.M.; Duckworth, A.D.; Clement, N.D.; McQueen, M.M. Fractures in older adults. A view of the future? Injury 2018, 49, 2161-2166. [CrossRef]

743. Lewiecki, E.M.; Leader, D.; Weiss, R.; Williams, S.A. Challenges in osteoporosis awareness and management: Results from a survey of US postmenopausal women. J. Drug Assess. 2019, 8, 25-31. [CrossRef]

744. Liu, J.; Curtis, E.M.; Cooper, C.; Harvey, N. State of the art in osteoporosis risk assessment and treatment. J. Endocrinol. Investig. 2019, 42, 1149-1164. [CrossRef]

745. Hagen, G.; Magnussen, J.; Tell, G.; Omsland, T. Estimating the future burden of hip fractures in Norway. A NOREPOS study. Bone 2020, 131, 115156. [CrossRef]

746. Schuit, S.; Van Der Klift, M.; Weel, A.; De Laet, C.; Burger, H.; Seeman, E.; Hofman, A.; Uitterlinden, A.; Van Leeuwen, J.; Pols, H. Fracture incidence and association with bone mineral density in elderly men and women: The Rotterdam Study. Bone 2004, 34, 195-202. [CrossRef] [PubMed]

747. Siris, E.S.; Chen, Y.-T.; Abbott, T.A.; Barrett-Connor, E.; Miller, P.D.; Wehren, L.E.; Berger, M.L. Bone Mineral Density Thresholds for Pharmacological Intervention to Prevent Fractures. Arch. Intern. Med. 2004, 164, 1108-1112. [CrossRef] [PubMed]

748. Kanis, J.; Adachi, J.D.; Cooper, C.; Clark, P.; Cummings, S.R.; Diaz-Curiel, M.; Harvey, N.; Hiligsmann, M.; Papaioannou, A.; et al.; The Epidemiology and Quality of Life Working Group of IOF Standardising the descriptive epidemiology of osteoporosis: Recommendations from the Epidemiology and Quality of Life Working Group of IOF. Osteoporos. Int. 2013, 24, 2763-2764. [CrossRef] [PubMed]

749. Lespessailles, E.; Cortet, B.; Legrand, E.; Guggenbuhl, P.; Roux, C. Low-trauma fractures without osteoporosis. Osteoporos. Int. 2017, 28, 1771-1778. [CrossRef]

750. Wu, Q.; Xiao, X.; Xu, Y. Evaluating the Performance of the WHO International Reference Standard for Osteoporosis Diagnosis in Postmenopausal Women of Varied Polygenic Score and Race. J. Clin. Med. 2020, 9, 499. [CrossRef]

(C) 2020 by the authors. Licensee MDPI, Basel, Switzerland. This article is an open access article distributed under the terms and conditions of the Creative Commons Attribution (CC BY) license (http://creativecommons.org/licenses/by/4.0/). 